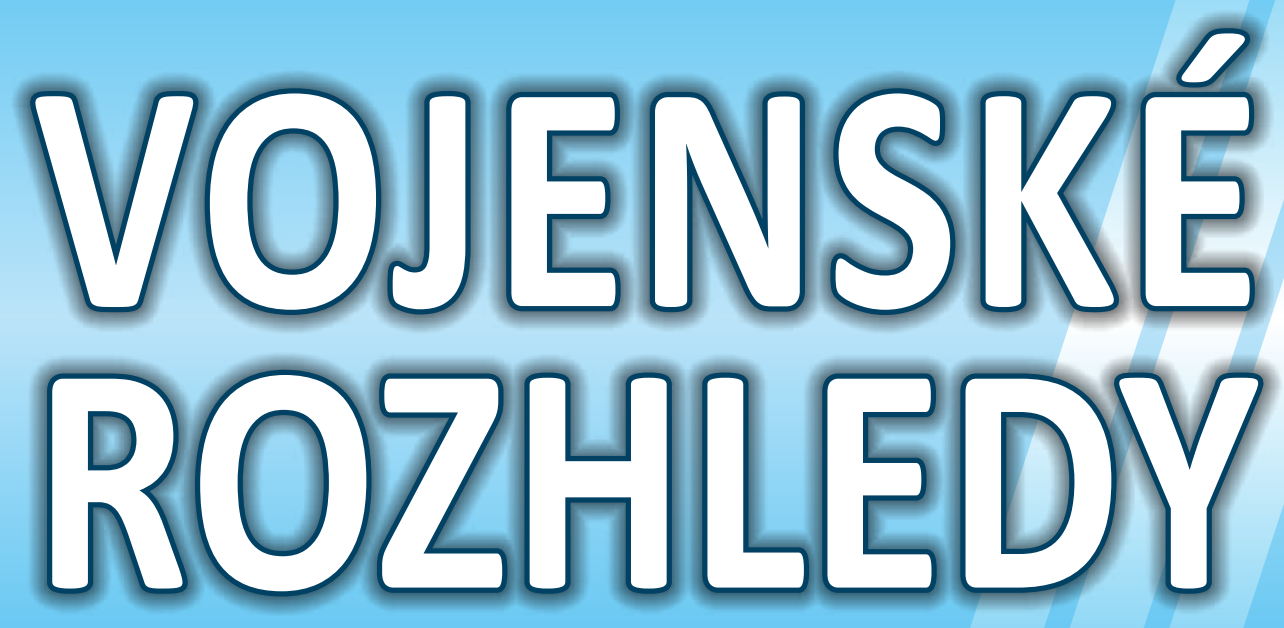

Czzech Millitarary Review

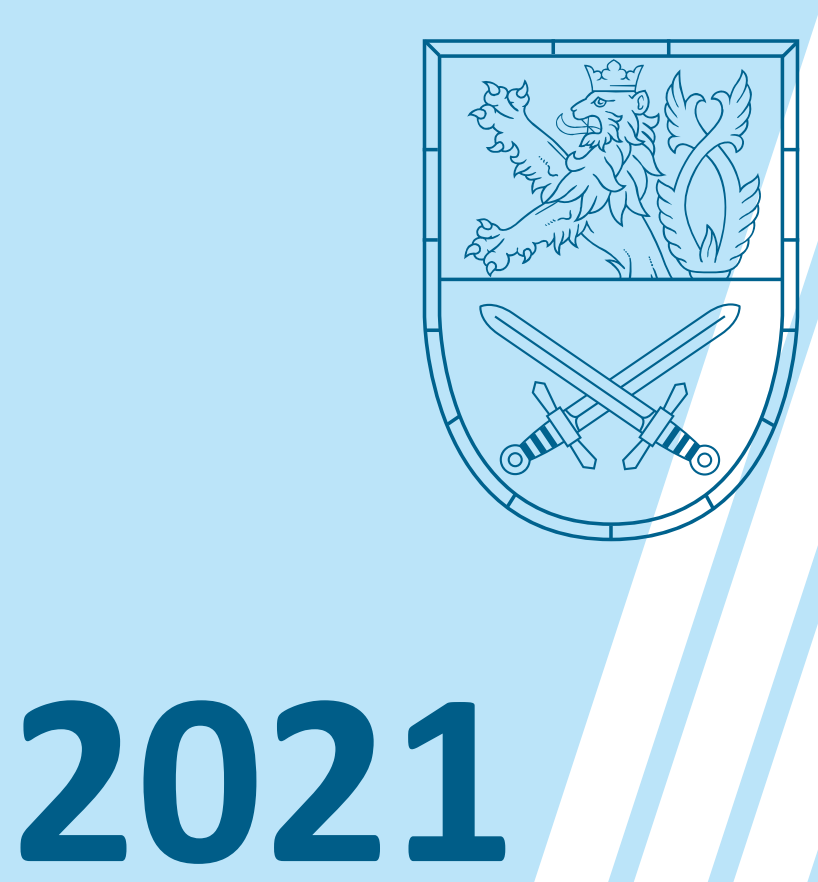




\section{VOJENSKOTEORETICKÝ ČASOPIS}
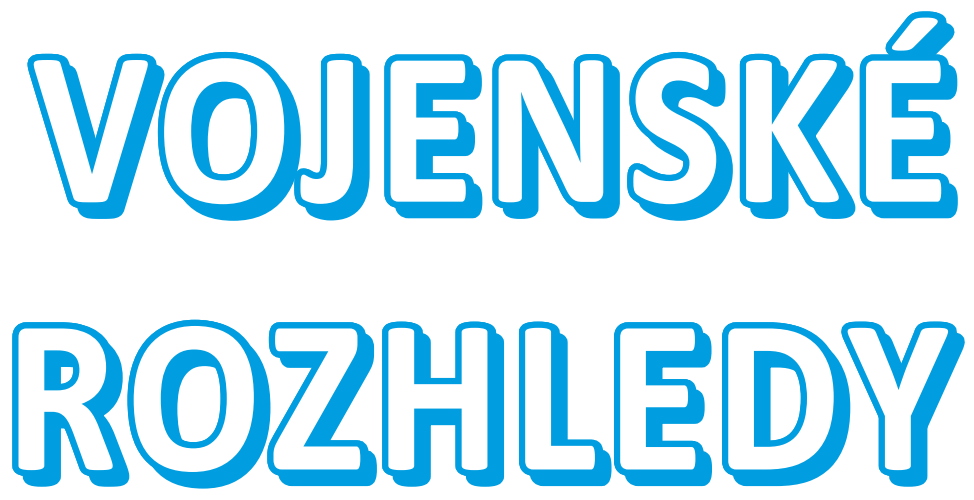

ROČNÍK 30 (62) 



\section{NATO po skončení studené války}

\section{NATO after the end of the Cold War}

\section{Jan Eichler}

Abstrakt: CČlánek se zabývá procesem rozšiřování NATO po roce 1990. Připomíná neveřejná jednání, která byla zahájena hned po skončení studené války a o kterých se v ČR zatím nepsalo. Z pohledu neoliberálního institucionalismu a zejména pak z pohledu nových členských států jde o proces velice pozitivní a přínosný. Ale z pohledu amerického neorealismu došlo k zásadním změnám v rovnováze bezpečnostních hrozeb, a proto jsou připomínány i kontroverzní dopady, především sílící militarizace a nárůst napětí na nové východní hranici NATO, kde má rozšířená Aliance poprvé ve svých dějinách prímou hranici s Ruskou federací, podél níž jsou z obou stran rozmístěny nové vojenské jednotky s nejmodernější výzbrojí, a kde narůstá počet i závažnost vojenských incidentů. Současná situace volá po přímých politických jednáních mezi oběma stranami, po snížení stávajícího mezinárodního napětí a po posunu od dosavadního negativního míru k míru pozitivnímu.

Abstract: The article analyses the process of the NATO enlargement after 1990. It starts by a detailed analysis of the secret negotiations which have been started just after the end of the Cold War. In the light of the institutional liberalism, the NATO enlargement is a positive process which satisfied especially new member states. But in the light of the American neorealism, this process resulted into profound changes in the balance of the security threats and into a large militarisation and tension at the new Eastern frontier of NATO in a direct neighbourhood with the Russia. New military units with the modern arms systems are deployed over there and we are witnessing a growing number of dangerous military incidents. As a result, the contemporary situation needs new political negotiations between two competitors and a shift from the contemporary negative Peace towards the positive Peace.

Klíčová slova: rozšiřování NATO, neorealismus, militarizace, vojenské napětí, vojenské incidenty.

Key words: NATO enlargement, neorealism, militarisation, military tension, military incidents. 


\section{ÚVOD}

Celá Evropa je znepokojena vysokým stupněm vojenského a politického napětí v oblasti mezi Ruskou federací (RF) a NATO, a to ve dvou strategicky významných oblastech. První z nich je Baltské moře, kde se novými členskými státy NATO staly Estonsko (Finský záliv), Lotyšsko a Litva. A v další stejně významné oblasti, tedy v Černomoří, RF a rozšířené NATO od přímého sousedství oddělují Ukrajina a Gruzie, které navíc v roce 2008 dostaly pozvánku do NATO. ${ }^{1}$ Ve všech pěti prípadech se jedná o bývalé státy SSSR. Navíc v Černomoři do NATO vstoupily Rumunsko a Bulharsko, dva bývalé členské státy Varšavské smlouvy.

V obou výše vzpomínaných oblastech RF navyšuje počty svých ozbrojených sil, modernizuje jejich výzbroj, pořádá rozsáhlá vojenská cvičení, během nichž dochází k velkému množství vojenských incidentů. NATO v tomto vývoji spatřuje naléhavou bezpečnostní hrozbu pro nové členské státy, které do svých řad přijalo v roce 2004, a tak jeho generální tajemník hovoři o ruských agresivních akcích. ${ }^{2}$ Naproti tomu nejvyšší ruští političtí a vojenští činitelé svůj dosavadní postup zdůvodňují jako odpověd' na proces rozšíření NATO po skončení studené války. Tento proces se tak stal velice aktuálním námětem, o kterém se diskutuje z nejrůznějších úhlů pohledu. Proto je mu věnován tento článek.

Všechny nové členské země získaly vysoce ceněné bezpečnostní záruky nejsilnějšího státu současného světa a staly se členy prestižního společenství sdílených hodnot. Ale právě výše vzpomínané podrážděné reakce RF ukázala, že proces rozšiřování NATO má i svoji odvrácenou stranu. Proto tento text hledá odpověd’ na několik výzkumných otázek. Především za prvé je to otázka hlavních mezníkủ zkoumaného procesu. Za druhé jde o otázku, proč je současná struktura vztahů na hranici mezi NATO a RF tak silně konfliktní? A za třetí jde o to, jaké jsou možné důsledky dosavadního vývoje?

\section{TEORIE A METODOLOGIE}

Tento článek je psán jako theory testing a zároveň i jako policy evaluative text. To znamená, že testuje náležitost neorealismu a že tak činí na základě hodnocení nejvýznamnějších událostí posledních 30 let. Základem je holistická teorie, ${ }^{3}$ tedy převaha vnějšího pohledu (outside scoop) nad vnitřním pohledem (inside scoop). Rozšiřování NATO po skončení studené války je zkoumáno především z pohledu institucí a ve světle vývoje

1 Bucharest Summit Declaration Issued by the Heads of State and Government participating in the meeting of the North Atlantic Council in Bucharest on 3 April 2008, art. 23.

2 The Secretary General's Annual Report 2020, 16 March, NATO. Dostupné na: https://www.nato.int/cps/ en/natohq/opinions_182236.htm.

3 Drulák, P. a kol. (2008): Jak zkoumat politiku: kvalitativní metodologie v politologii a mezinárodních vztazích. Praha: Portál. 
status quo, zatímco hodnocení úlohy konkrétních lidí a jejich úlohy je až druhořadé. ${ }^{4}$ Celý text je psán jako detailní vyprávění (narace), tedy jako příběh vyprávěný chronologickým způsobem s cílem vysvětlit, jak se zkoumaná událost odehrávala. ${ }^{5}$ Tento způsob psaní je také nazýván analytické vyprávění (analytic narrative, AN) o vývoji a příčinných souvislostech zvoleného prrípadu. ${ }^{6}$ Narativní výklad „nepostupuje od klasifikace k obecnému zákonu, nýbrž od klasifikace k výkladu odlišnosti" ${ }^{7} \mathrm{~V}$ rámci AN se tento text zaměřuje na klíčové události ve vývoji NATO během posledních 30 let a na vzájemné interakce, které jedny aktéry omezují, aby druhé naopak zvýhodňovaly. ${ }^{8}$

Pokud jde o teorii, text vychází především z odkazu amerických neorealistů, kteří zdůrazňují, že z hlediska geografického je velký rozdíl mezi námořními a kontinentálními mocnostmi. Námořní mocnosti jsou chráněny mořem nebo oceánem, ${ }^{9}$ nacházejí se daleko od místa možné vojenské konfrontace, ${ }^{10}$ nemusejí mít strach z devastace svého vlastního území. ${ }^{11}$ Zaměřují se především na námořní zbraňové systémy (zejména letadlové lodi) a nemusejí věnovat tak velkou pozornost pozemnímu vojsku. Mohou spoléhat na projekci síly na velké vzdálenosti, zejména námořních sil, ${ }^{12}$ a využívat i potenciál svých případných spojenců v místě hrozícího vojenského střetu, které se nachází daleko od jejich území. Právě tyto postuláty jsou velmi inspirativní pro hodnocení vývoje NATO během posledních 30 let. $V$ jejich světle jsou námořní mocností USA jakožto hegemon NATO, zatímco RF je ve vztahu k rozšiřujícímu se NATO v pozici kontinentální mocnosti.

Neorealisté přikládají velký význam studiu strukturálních důsledků vyvažovacích strategií. Říkají, že slabší, zaostávající státy vždy usilují o to, aby se vymanily z podřadného postavení, a tak nakonec vynakládají větší úsilí nežli státy v nadřazeném postavení. Pro pozemní mocnosti je udržování vyrovnaného postavení nákladnější nežli pro mocnosti námořní. Ale zároveň s tím neorealisté varují, že námořní mocnosti si mohou situaci zkomplikovat tím, když se blíží k pozemním mocnostem. ${ }^{13} \mathrm{~A}$ právě tento poslední důsledek je velkou inspirací pro hodnocení vývoje NATO za poslední tři desetiletí. Již na počátku tohoto století totiž nastala situace, kdy se USA jako hegemon NATO prriblížily $\mathrm{k}$ hranici RF jako pozemní mocnosti a $\mathrm{v}$ důsledku toho sílí konfliktní potenciál v jejich vzájemných vztazích.

4 Bližze viz: Mearsheimer, J. J. (2001): The Tragedy of Great Power Politics. New York, NY: W.W. Norton.

5 Kořan, M. (2008): Člověk, poznání a mezinárodní politika: pragmatismus a vědecký realismus jako filozofie vědy v mezinárodních vztazích. Praha: Ústav mezinárodních vztahů.

6 Gerring, J. (2009): Case study research: principles and practices. Cambridge: Cambridge University, 2007

7 Ricoeur, P. (2000): Čas a vyprávění. Praha: OIKOYMENH, s. 181

8 Bates, R. - Greif, N. - Levi, M. - Laurent J. (1998): Analytic Narratives. Princenton: Princenton University Press

9 Little, R. (2007): The Balance of Power in International Relations: Metaphors, Myths and Models. Cambridge: Cambridge University Press, s. 238-239.

10 Dostupné na: https://www.britannica.com/topic/sea-power.

11 Harding, R. (2008): Naval History 1680-1850. Burlington: Ashgate.

12 Huntington, S. P. (1958): Arms Races: Prerequisites and Results. Public Policy, Vol. 8(1), s. 52.

13 Parent, J. M.-Rosato, S. (2015): Balancing in Neorealism. International Security, Vol. 40(2) Fall 2015, s. 64. 


\section{UVOLNĚNÍ VOJENSKÉHO NAPĚTí V ROCE 1990}

Jedním z hlavních symbolů konce studené války je znovusjednocení Německa ${ }^{\mathbf{1 4}}$.Jeho součástí se stala tzv. Národní lidová armáda (NLA) NDR, jež v té době měla celkem 137,7 tis. vojáků (z toho 50 tis. vojáků základní služby). Velice významnou úlohu sehrála Smlouva o konvenčních silách v Evropě (Conventional Armed Forces in Europe, CFE) ${ }^{15}$, která stanovila stropy vojenské síly znovusjednoceného Německa ${ }^{16}$ i stropy pro počty tanků, bojových vozidel pěchoty, dělostřeleckých systémů, bojových letadel a vrtulníků, ${ }^{17}$ a stala se tak symbolem demilitarizace Evropy po skončení studené války. Ještě na konci roku 1990 byla schválena Pařižská charta za novou Evropu, která oficiálně vyhlásila konec studené války. ${ }^{18}$ Zároveň s tím byly podepsány smlouva START I (1991) a START II (1993), které výrazně snížily stavy strategických jaderných sil USA a bývalého SSSR. A v roce 1990 George W. H. Bush, 41. prezident USA, ve svém projevu „Toward a New World Order“ oznamoval nástup nového mezinárodního uspořádání opírajícího se o mezinárodní právo a mezinárodní organizace, o zrušení hranic, o demokracii, mír a svobodu pro všechny. ${ }^{19}$ Nastalo rozsáhlé snižování vojenských výdajů, tedy čerpání tzv. mírových dividend. Ale nedílně s tím se začalo uvažovat o rozšiřování NATO směrem na východ.

\section{$3 \quad$ PRVNÍ ÚVAHY O ROZŠIŘOVÁNÍ NATO V DOBĚ GEORGA BUSHE ST.}

Přední americká historička Mary Elise Sarotte ${ }^{20}$ připomíná, že na počátku jednání byl projev, se kterým 31. 12. 1989 vystoupil tehdejší francouzský prezident François Mitterrand. Nastínil v něm svoji vizi Evropské konfederace, ve které počítal i se SSSR, ale nezahrnoval do ní USA. A právě proto narazil na nepochopení v tehdejší SRN a na odpor v USA, které něco takového nechtěly vůbec dopustit. ${ }^{21}$ Tento projekt měl nesporný politický potenciál $v$ době, kdy se hovořilo o novém, inkluzivním celoevropském

14 Zelikow, P.-Rice, C. (1995-1997): Germany Unified and Europe Transformed: A Study in Statecraft. Cambridge, MA: Harvard University Press.

15 Treaty on Conventional Armed Forces in Europe. Dostupné na: https://www.osce.org/ library/14087?download=true.

16 Na jejich základě pak bylo šest bojových a čtyři rámcové divize pozemního vojska bývalé NDR preměněno na šest brigád územní obrany.

17 Text of the Treaty - United States Department of State.

18 Charter of Paris, OSCE. Dostupné na: https://www.osce.org/mc/39516?download.

19 Address Before a Joint Session of the Congress on the Persian Gulf Crisis and the Federal Budget Deficit.

20 Sarotte, M. E. (2014): A Broken Promise? What the West Really Told Moscow about NATO Expansion. Foreign Affairs, Vol. 93, September/October 2014, s. 90-97.

21 Musitelli, J. (2001-2002): " François Mitterrand, architecte de la Grande Europe: le projet de confédération européenne (1990-1991) ». Revue internationale et stratégique, n² 82, s. 18-28. 
bezpečnostním uspořádání a kdy londýnský22 a římský summit NATO23 už o tehdejším SSSR nehovořily jako o hrozbě pro bezpečnost zemí NATO. Mitterrandův projekt měl př́iznivý ohlas i Moskvě, kde se s velkými nadějemi hovořilo o OBSE a o Evropské Radě bezpečnosti, což bylo $s$ francouzským pojetím hodně souměritelné. ${ }^{24}$ Nakonec však stejně nebyl úspěšný, a tak dostal nálepku mrtvě narozeného dítěte..$^{25}$

\section{1 Životní úspěch kancléře Helmutha Kohla}

Mezitím, 6. 2. 1990, Hans-Dietrich Genscher řekl Douglasovi Hurdovi, ${ }^{26}$ že Michail S. Gorbačov si nepřeje žádné rozšiřování NATO nejen na území někdejší NDR, ale ani nikde jinde v prostoru Varšavské smlouvy. A o tři dny později to $M$. Gorbačov řekl přímo Jamesovi Bakerovi během jednání $v$ Moskvě. Ale ten při té př́ležitosti navštívil velvyslance SRN v Moskvě a předal mu dva tajné dopisy pro Helmutha Kohla. Autorem prvního byl prezident Bush, který nezavrhoval ani možnost budoucího rožsiření NATO na východ. Druhý dopis byl od Bakera a měl skromnější cíl: do NATO by mělo být zapojeno celé znovusjednocené Německo, ale ještě nebylo jasné, zda se na celé toto území bude vztahovat také jurisdikce NATO. J. Baker napsal, že mu Gorbačov řekl, že rozšiřování zóny NATO je nepríijatelné, a že on z toho vyvozuje, že zachování NATO $v$ tehdejších hranicích by bylo pro Moskvu přijatelné. A hlavní pozornost zaměřoval na dva úkoly: vyjednat zvláštní statut pro východní část SRN a nalézt takové způsoby, aby Gorbačov neztratil tvář. Tehdejší prezident USA tedy zosobňoval maximalistický přístup, jeho ministr zahraničních věcí zastával spíše minimalistický přístup. Proto 5. 5. 1990 ujištoval Eduarda Ševarnadzeho, ${ }^{27}$ že nová bezpečnostní struktura v Evropě nebude exkluzivní, ale inkluzivní. ${ }^{28}$

Mezitím v Moskvě jednal (10. 2. 1990) sám kanclér Kohl, ${ }^{29}$ který vše podřizoval svému historickému cíli: dosáhnout znovusjednocení Německa. Proto se řídil Bakerovým minimalistickým pojetím a Gorbačova ústně ujistil, že v případě sjednocení Německa se NATO nebude rozšiřovat dále na východ. A v následujících dnech odeslal tajné telegramy Mitterrandovi a Thatcherové, aby Francii i V. Británii ujistil, že ze znovusjednocení Německa

22 The London Declaration on a transformed North Atlantic Alliance, 6. 7. 1990. Dostupné na: https://www. nato.int/cps/en/natohq/official_texts_23693.htm.

23 Rome Declaration on Peace and Cooperation made by the Heads of State and Government of the Atlantic Alliance, Rome, 8. 11. 1991. Dostupné na: https://www.cvce.eu/content/ publication/2003/4/2/0de2c948-ce90-49b9-9178-9d102dd6bf79/publishable_en.pdf

24 Kropatcheva, E. (2015): The Evolution of Russia's OSCE Policy: From the Promises of the Helsinki Final Act to the Ukrainian Crisis. Journal of Contemporary European Studies, Vol. 23 (1), s. 6-24.

25 Dumas, R. (2001): «Un projet mort-né: la Confédération européenne». Politique étrangère, $\mathrm{n}^{\circ}$ 3, s. 687-703.

26 Britský ministr zahraničních věcí v letech 1989-1995.

27 Ministr zahraničních věcí SSSR v letech 1985-1990, později prezident Gruzie.

28 Fix, L. (2012): European Security and the End of the Cold War: Gorbachev's Common European Home Concept and its Perception in the West (unpublished manuscript). London School of Economics.

29 Funkci zastával v letech 1982-1998, do dějin vešel jako „kanclér sjednotitel“. 
nemusejí mít strach. Za svůj úspěch zaplatil 12 mld. tehdejších marek na výstavbu bytů a kasáren pro sovětské vojáky, kteří opouštěli posádky v NDR. ${ }^{30}$

\subsection{Zákulisní jednání}

Bushova administrativa již na začátku roku 1990 vnitřně rozhodla, že se nové bezpečnostní uspořádání v Evropě nebude nijak zásadně lišit od doby studené války a že jeho páteří zůstane NATO. ${ }^{31} \mathrm{~A}$ již v polovině téhož roku J. Baker varoval prezidenta Bushe, že největším nepřítelem NATO je právě OBSE. ${ }^{32}$ To vše prezidenta utvrdilo v přesvědčení, že NATO jakožto osvědčená mezinárodní organizace musí i nadále mít výlučný charakter, a to bez členství SSSR. ${ }^{33}$ Proto také prezident Bush st. na setkání v Camp Davidu vyčinil Kohlovi slovy, že vyhráli USA a jejich spojenci a že se Moskvě nesmí ustupovat. A vzápětí důrazně upozornil francouzského prezidenta Mitterranda, že v Evropě není a nebude místo pro nějakou celoevropskou organizaci pro spolupráci a bezpečnost. Bush chtěl zachovat NATO jako něco, co se osvědčilo, a připravovat se na jeho budoucí rozšiřování směrem na východ. Jeho důraznost narůstala úměrně tomu, jak tehdejší velvyslanec v Moskvě John Matlock informoval, že Gorbačovova pozice a vliv v Rusku slábnou, a tak mu zbývá stále méně a méně času a sil na zahraniční politiku. ${ }^{34}$

\subsection{O peníze jde vždy až v první řadě 35}

A zákulisně se vzápětí po skončení studené války vyjednávalo také o finanční pomoci pro postkomunistické země. Na to upozornil Jeffrey Sachs, přední americký ekonom, akademik a politický analytik. ${ }^{36}$ On osobně hned na samém počátku devadesátých let vyjednával s tehdejším moskevským reformátorem Grigorijem Javlinským, aby byla tehdejšímu SSSR poskytnuta velká dolarová pomoc. Mělo jít o stejnou půjčku, jakou těsně před tím dostalo Polsko. Jenomže tehdejší administrativa USA v létě 1991 tento návrh

30 Sarotte, M. E. (2014): A Broken Promise? What the West Really Told Moscow about NATO Expansion, op. cit., s. 96.

31 Sarotte, M. E. (2009): The Struggle to Create Post-Cold War Europe. Princenton: Princenton University Press.

32 Deal or No Deal? Deal or No Deal? The End of the Cold War and the U.S. Offer to Limit NATO Expansion. International Security, Vol. 40(4), s. 7-44.

33 Nünlist, Ch. (2017): Contested History: Rebuilding Trust in European Security. In: STRATEGIC TRENDS 2017. Key Developments in Global Affairs, s. 21. ETH Zürich.

34 Matlock, J. F. (2005): Reagan and Gorbachev: how the cold war ended. New York: Random House.

35 Oblíbené rčení Václava Klause, prezidenta ČR v letech 2003-2013.

36 Je to jeden z hlavních autorů projektů celosvětového významu, zejména pak MDG. V letech 2004 a 2005 jej časopis Time zařadil mezi 100 nejvlivnějších lidí světa. 
jednoznačně odmítla. A právě proto Sachs tvrdí, že už tehdy se předpokládalo, že Polsko se jednou stane členem NATO, zatímco Rusko tam přizváno nebude. A uzavírá, že tento postup zmařil možnost vytvoření celoevropského rámce kooperativní bezpečnosti. ${ }^{37}$

\section{ROZPAD SSSR JAKO VÝZVA I TEST}

Vzápětí po odmítnutí finanční pomoci tehdejšímu SSSR prezident USA H. W. Bush na zasedání Národní bezpečnostní rady (NSC) USA v záŕí 1991 nastolil otázku, zda má, či nemá být podpořen proces rozpadu SSSR. Ministr zahraničních věcí J. Baker a poradce pro otázky národní bezpečnosti Brent Scowcroft se chovali jako defenzivní realisté. Tvrdili, že je lepší jednat s jedním partnerem, kterého už znají, než se šestnácti nástupnickými a pravděpodobně i nepředvídatelnými státy. ${ }^{38}$ Před rozšiřováním vlivu USA upřednostňovali stabilitu v komplikované oblasti. ${ }^{39}$ Ale nakonec převážil vliv ofenzivních realistů ( $v$ jejichž čele stál tehdejší ministr obrany Dick Cheney, pozdější viceprezident USA v letech 2001-2009), jejichž cílem bylo šírení moci a vlivu do neruských oblastí SSSR. ${ }^{\mathbf{4 0}}$

\subsection{Vítězství ofenzivních realistů v USA}

V této souvislosti Joshua R. Itzkowitz Shifrinson z Texaské univerzity připomíná Bakerův tajný dopis pro kancléře Kohla, v němž stojí, že během svých jednání v Moskvě předestřel Gorbačovovi dvě možné podoby sjednoceného Německa. Tou první mělo být Německo existující mimo NATO, ale nekontrolovatelné a nepředvídatelné. Druhá možnost byla Německo kontrolované v rámci NATO, přičemž NATO by se pak nerozšiřilo ani o píd' směrem na východ. ${ }^{41}$ Baker v květnu 1990 Ševarnadzeho ujištótoval, že USA nebudou usilovat o oddělení východní Evropy od SSSR a že jejich cílem je vybudovat stabilní Evropu, a že přitom budou spolupracovat s SSSR.42 Skutečnost, že přitom nebyl podepsán žádný písemný slib, Shifrinson hodnotí jako součást složité šachové partie, na jejímž konci bylo stupňované rozšíření NATO daleko na východ. ${ }^{43}$ A vyjadřuje souhlas s názorem, že USA

37 Sachs, J. (2018): A New Foreign Policy: Beyond American Exceptionalism. New York: Columbia University Press.

38 Bush, G. H. W. - Scowcroft, B. (1998): A World Transformed. New York: Knopf.

39 Nau, H. (2012): Realism. In: Routledge Handbook of American Foreign Policy. London: Routledge, S. 70.

40 Tamtéž.

41 Deal or No Deal? Deal or No Deal? The End of the Cold War and the U.S. Offer to Limit NATO Expansion, op. cit.

42 Savranskaya, S. - Blanton, T. S. (2016): The Last Superpower Summits: Gorbachev, Reagan, and Bush. Conversations that Ended the Cold War. Budapest: Central European University Press, s. 634.

43 NATO Enlargement - Was There a Promise? International Security, op. cit., s. 190. 
v roce 1990 Ševarnadzeho takříkajíc napálily44 a jasně přehrály slábnoucího Gorbačova, což byl úspěch, jenž je v dějinách mezinárodních vyjednávání velice ojedinělý. ${ }^{45}$

\subsection{Co bylo a nebylo slíbeno?}

Ze všech nejkritičtější jsou ruští politikové, vojáci a historici. Ti téměř bez rozdílu hovoři o zradě, které se měl Západ (a jmenovitě USA) na samém počátku devadesátých let dopustit tím, že nesplnil slib, který dal, ${ }^{46}$ a že tehdejší sovětské lídry promyšleně podvedl. ${ }^{47}$ Připomínají, že ještě v říjnu 1993 tehdejší mistr zahraničních věcí USA Warren Christopher dával v Moskvě Jelcinovi záruku plného zapojení Ruska do budoucího bezpečnostního uspořádání v Evropě, což tehdejší ruský prezident označil za „velkou myšlenku“.48 Odtud už pak bylo jen kousek k pozdějšímu pocitu, že byl podveden, což nakonec veřejně vyhlásil na zasedání OBSE v Budapešti v prosinci 1994, když hovořil o hrozbě posunu směrem ke studenému míru. 49

Na počátku roku 1990 nebyly podepsány „žádné kategorické závazky, žádné slavnostní sliby ani záruky“, že v budoucnu nedojde k rozšiřování NATO, 50 což ostatně potvrdil i Ševarnadze v roce 2009. ${ }^{51} \mathrm{~V}$ roce 1990 nejvyšší představitelé SSSR, ale třeba i Polska, stále věřili, že Varšavská smlouva přežije, aby byla zachována stabilita tváří v tvář nevyzpytatelným důsledkům sjednocení Německa. ${ }^{52}$ Pokud byl nějaký nesplněný slib, pak to nanejvýš mohl být několikrát opakovaný ústní slib, že bude nastolen systém kooperativní bezpečnosti, který bude inkluzivní a zahrne všechny evropské země, včetně tehdejšího SSSR. ${ }^{53}$

44 McGovern, R. (2014): When the US Welched on Its NATO Promise. Baltimore Sun, 17. 7. 2014.

45 Sarotte, M. E. (2014): A Broken Promise? What the West Really Told Moscow about NATO Expansion, op. cit., s. 97.

46 Putin, V. (2014): Address by President of the Russian Federation, 18. 3. 2014; Putin, V. (2014): Meeting of the Valdai International Discussion Club, 14. 10. 2014.

47 Spohr, K. (2012): Precluded or Precedent-setting? The NATO Enlargement Question in the Triangular Bonn-Washington-Moscow Diplomacy of 1990/1991 and Beyond. Journal of Cold War Studies, 14, No. 4, S. 4-54.

48 Goldgeier, J. (2016): Promises Made, Promises Broken? What Yeltsin Was Told About NATO in 1993 and Why It Matters. War on the Rocks, 12. 9. 2016.

49 Tamtéž.

50 Krammer, M. (2009): The Myth of a No-NATO-Enlargement Pledge to Russia. The Washington Quarterly, Vol. 32 (2), s. 7-44.

51 Interview with Eduard Shevardnadze: We Couldn't Believe that the Warsaw Pact Could Be Dissolved. Spiegel.de, 28. 11. 2009. Dostupné na: https://www.spiegel.de/international/ europe/interview-with-eduard-shevardnadze-we-couldn-t-believe-that-the-warsaw-pact-could-bedissolved-a-663595.html.

52 NATO Enlargement - Was There a Promise? International Security, Vol. 42(1), Summer 2017, s. 188.

53 Nünlist, Ch. (2017): Contested History: Rebuilding Trust in European Security, op. cit., s. 20. 


\section{BILL CLINTON JAKO POLITICKÝ GARANT PRVNÍ VLNY ROZŠIǏOVÁNÍ NATO}

Počínaje rokem 1993 přicházely z bývalých satelitních států SSSR stále naléhavější žádosti o získání bezpečnostních záruk NATO. Nejvýrazněji se angažovali polský prezident Lech Wałęsa a prezident České republiky Václav Havel. Ti se na tehdejšího prezidenta USA B. Clintona obrátili s naléhavou žádostí o přijetí jejich zemí do NATO během rozhovoru ve washingtonském Muzeu holocaustu v dubnu 1993. Na stranu polského a českého prezidenta se pak ještě přiklonili významní američtí činitelé: bývalý prezidentův poradce pro otázky národní bezpečnosti Anthony Lake ${ }^{54}$ a náměstek ministra zahraničních věcí pro evropské záležitosti Richard Holbrooke. ${ }^{55}$

Tehdejší český prezident označoval NATO za jedinou účinnou organizaci schopnou odvrátit hrozby typu války, jaká v té době právě probíhala v Bosně. Varoval, že pokud se NATO nerozšírí, vytvoři se ve střední Evropě bezpečnostní vakuum, které se stane pokušením pro nostalgiky mocenských bloků a regionální nadvlády. Dále tvrdil, že pokud se NATO nerozšíríi, stane se beznadějně zastaralým klubem veteránů studené války. $A$ uzavíral, že NATO se nesmí svého východního rozšíření zdráhat s poukazem na podráždění, jaké by to vyvolalo v Rusku. ${ }^{56} \mathrm{~A}$ v Polsku se argumentovalo, že země $\mathrm{V} 4$ natrvalo zakotví ve společenství sdílených hodnot a získají jistoty nezvratitelnosti politických změn prosazených po roce 1989. ${ }^{57}$ Prezident L. Wałęsa stejně jako ministr zahraničních věcí Krzysztof Skubiszewski zdůrazňovali, že v Polsku nejsou žádné národnostní menšiny, že Polsko je zcela spokojeno se svými hranicemi a nepožaduje žádné jejich změny, a že má dobré vztahy se všemi svými sousedy včetně Ruska. ${ }^{58} \mathrm{~A}$ dodávali, že tyto dobré vztahy chtějí udržovat i po vstupu do NATO. 59

\section{PARTNERSHIP FOR PEACE (PFP) JAKO PRVNÍ KROK ROZŠIŘOVÁNÍ NATO}

Ale i přes výše zmíněné výhrady NATO v roce 1997 na summitu v Madridu rozhodlo o první vlně svého rozšíření. Rusko bylo v té době hodnoceno jako přiliš slabé a okrajové,

54 Velice zkušený a vlivný diplomat, funkci zastával v letech 1993-1997.

55 Gaddis, J. L (1998): We Now Know: Rethinking Cold War History. Oxford: Clarendon Press, s. 148.

56 The New York Times, 15. 5. 1997. Dostupné na: https://www.nytimes.com/1997/05/15/world/forhavel-a-nato-open-to-all-democracies.html.

57 Cimoszewicz, W. (1996): Building Poland's security: Membership of NATO a key objectiv. NATO Review, Vol. 44(3), s. 3-7.

58 Yeltsin, B. (1993): „Understands“ Polish Bid for a Role in NATO. The New York Times, 26. 8. 1993. Dostupné na: $\quad$ https://www.nytimes.com/1993/08/26/world/yeltsin-understands-polish-bid-for-a-role-in-nato. html.

59 Gorska, J. A. (2010): Dealing with a Juggernaut: Analyzing Poland's Policy toward Russia, 1989-2009. Lanham: Rowman and Littlefield. 
a proto byly jeho zájmy ignorovány. ${ }^{60}$ Kontrast mezi sílou NATO na jedné straně a Ruska na druhé byl tak výrazný, že politika Západu začala být velmi důrazná. ${ }^{61}$

Důležitým mezníkem procesu rozšiřování NATO se stal program Partnerství pro mír (Partnership for Peace, PfP), který byl schválen na summitu Aliance 11. 1. 1994 v Bruselu. ${ }^{62}$ Byl určen pro bývalé země Varšavské smlouvy, které se $v$ té době staly zeměmi neutrálními. Byl nabídnut i všem postsovětským zemím, včetně Ruské federace. Jeho hlavním posláním bylo pomoci všem účastníkům s nezbytnými reformami jejich armád, s jejich modernizací, se sestavováním vojenských rozpočtů, se změnami bojové prípravy, včetně organizace společných cvičení. K programu se připojilo celkem 34 zemí, ${ }^{63}$ přičemž nebyl nikomu vnucován, naopak reagoval na zájmy a požadavky zemí, které předtím spontánně ukončily své členství ve Varšavské smlouvě.

A pouhý jeden den po bruselském summitu NATO se v Praze sešel prezident Clinton s prezidenty ČR, SR, Polska a Mad'arska a tam již zaznělo, že otázka už nestojí, zda se NATO bude či nebude rozšiřovat, ale že je otázkou, kdy a jak to proběhne. A další zlom nastal 31. srpna téhož roku, kdy byl dokončen odsun ruských vojsk z východního Německa, kterých tam původně bylo přes půl milionu. Výše vzpomínaná M. E. Sarotte píše, že právě od tohoto dne se začalo prosazovat mnohem důraznější pojetí rozšiřování NATO. ${ }^{64}$

Po první vině rozšíření (1999: Polsko, Mad'arsko a ČR) se rozloha NATO rozšířila o téměř půl mil. km², kde žije celkem 60 mil. obyvatel. NATO získalo novou strategickou hloubku a nové možnosti pro vnější vyvažování. Proto již samotné př́ípravy první vlny rozšiřování NATO v Rusku znovu oživily obavy z obkličování. Ty se odrazily především v Primakovově doktríně z roku 1997, která se zaměřila na vyvažování jednostranného postupu vítěze studené války ${ }^{65}$. A pak přišla ještě závažnější událost: vzdušná válka NATO proti srbsko-černohorské Jugoslávii na jaře 1999. Operation Allied Force 1999 (OAF) byla v Rusku vnímána jako brutální zásah proti menšímu slovanskému bratru a potažmo i jako projev antiruského zaměření celého NATO. ${ }^{66}$

60 Sakwa, R. (2015): The death of Europe? Richard Sakwa looks at continental fates after Ukraine. International Affairs, Vol. 91(3), May 2015, s. 553-579.

61 Sarotte, M. E. (2014): 1989: The Struggle to Create Post-Cold War Europe, op. cit., s. 229.

62 NATO Headquarters, Brussels,10-11 January 1994. Declaration of the Heads of State and Government Participating in the meeting of the North Atlantic Council, 11. 1. 1994. Dostupné na: https://www.nato.int/docu/comm/comm94.htm.

63 Borawski, J. (1995): Partnership for Peace and beyond. International Affairs, No. 71(2), April, s. 233-246.

64 Ona sama použila výraz more „agressive expansion“.

65 Rumer, E. (2019): The Primakov (Not Gerasimov) Doctrine in Action, 5. 6. 2019. Dostupné na: https:// carnegieendowment.org/2019/06/05/primakov-not-gerasimov-doctrine-in-action-pub-79254.

66 Deudney, D. - Ikenberry, G. J. (2009-2010): The Unravelling of the Cold War Settlement. Survival: Global Politics and Strategy, Vol. 51, No. 6 (December 2009-January 2010), s. 39-62. 


\section{ROZŠIŘOVÁNÍ NATO POHLEDEM AMERICKÝCH}

\section{A ZÁPADOEVROPSKÝCH AKADEMIKU゚}

Rozšiřování NATO se stalo velkým námětem diskusí mezi akademiky a odborníky především v USA, které v tomto procesu hrály rozhodující úlohu. Liberálové tento proces obhajovali se slovy, že posílí rodící se demokracie ve střední Evropě a nedílně s tím do potenciálně turbulentní oblasti rozširíi zkušenosti NATO se zvládáním mezinárodních krizí. ${ }^{67}$ Argumentovali, že konec studené války otevřel rozsáhlý prostor pro institucionalizovanou mezinárodní bezpečnostní spolupráci, jejímiž nástroji a garanty budou právě osvědčené instituce, zejména NATO. ${ }^{68}$ Vyhlašovali, že rozšiřování NATO směrem na východ úspěšně odvrátí bezpečnostní soupeření69 a nacionalismus, který v minulosti opakovaně vedl k vypuknutí ničivých válek. ${ }^{70}$

Naproti tomu neorealisté namítali, že jde o expanzi a o rozšíření sféry vlivu USA, a varovali, že by to mohlo vyvolat tvrdou odpověd' Moskvy. ${ }^{71}$ Zakladatel neorealismu Kenneth Waltz ${ }^{72}$ již v roce 1993 zdůrazňoval, že význam NATO by měl po skončení dlouhého období bipolární konfrontace trvale klesat. ${ }^{73}$ Argumentoval, že mezinárodní organizace jsou vždy nástrojem národních vlád k prosazování jejich zájmů74 a že pokud se NATO bude rozšiřovat, bude dělat především to, co si budou přát USA jakožto hlavní vítěz studené války. ${ }^{75}$ Tvrdil, že tak jako přírodě škodí vakuum, tak mezinárodním vztahům neprospívá nevyvážená síla dominantního státu. ${ }^{76}$ Její nebezpečí spatřoval především v otevření prostoru pro unilateralismus a pro rozmařilost politických vůdců zemí či koalic, kterým chybí protihráč, který by jejich vliv vyvažoval. Dále varoval, že se bude rozšiřovat i sféra působnosti a bezpečnostní odpovědnosti NATO a budou se navyšovat náklady s tím spojené. Předpovídal, že nové členské země budou od NATO požadovat bezpečnostní záruky, a tím budou Alianci zatahovat do destabilizujících událostí na východ od svých hranic.

67 Bliže např. Duffield, J. S. (1994-1995): NATO's Functions after the Cold War. Political Science Quarterly, Vol. 109, No. 5 (Winter, 1994-1995), s. 763-787.

68 Keohane, R. O. - Martin, L. L. (1995): The Promise of Institutionalist Theory. International Security, Vol. 20, No. 1 (Summer, 1995), s. 39-51.

69 Art, R. J. (1996): Why Western Europe Needs the United States and NATO. Political Science Quarterly, Vol. 111, No. 1 (Spring 1996).

70 Keohane, R. (1993): The Diplomacy of Structural Change: Multilateral Institutions and State Strategies. In: Haftendorn, H. - Tuschhoff, C. (eds.): America and Europe in an Era of Change. Boulder, CO: Westview Press, s. 53.

71 Walt, S. M. (1998): International Relations: One World, Many Theories. Foreign Policy, No. 110, Special Edition: Frontiers of Knowledge (Spring, 1998), s. 29-32, 34-46.

72 Profesor mezinárodních vztahů na University of California, Berkeley and Columbia University.

73 Walt, S. M. (1998): International Relations: One World, Many Theories, op. cit., s. 75-76.

74 Strange, S. (1996): The Retreat of the State: The Diffusion of Power in the World Economy. Cambridge: Cambridge University Press.

75 Waltz, K. W. (2000): NATO expansion: A realist's view. Contemporary Security Policy, Vol. 21, Issue 2: Explaining Nato Enlargement, s. 35.

76 Tamtéž, s. 23-38. 
Dále Waltz připomněl velmi důležitou úlohu dvou dalších faktorů. Prvním z nich byly zájmy a očekávání zbrojařských firem USA, které si expanzi NATO spojovaly především se získáním nových odbytišt' pro svoje výrobky. ${ }^{77}$ A nedílně s tím připomněl i osobní zájmy a pohnutky velkého množství aliančních úředníků, ${ }^{78}$ jejichž hlavním zájmem je přesvědčit své okolí o nezbytnosti Aliance, uhájit své funkce a dalším rozšířením ještě více zvýraznit svůj význam a důležitost. ${ }^{79} \mathrm{~A}$ na závěr položil hypotetickou otázku: Jak by se chovaly USA, kdyby studenou válku místo nich vyhrálo Rusko, a to by se posléze rozhodlo, že na americký kontinent rozšírí Varšavskou smlouvu a bude to zdůvodňovat šířením hodnot a stability do Střední Ameriky. ${ }^{80}$

Jak v USA, tak i v západní Evropě zaznívaly názory řady skeptiků. Například John Lewis Gaddis, profesor vojenské a námořní historie na universitě Yale, kritizoval okázalé vyloučení Ruska coby bývalého neprítele a tzv. výběrový sentimentalismus, tedy podléhání sentimentálním argumentům jedné části států někdejší Varšavské smlouvy. ${ }^{81}$ Johann Galtung, norský matematik a sociolog, zakladatel oboru Peace Studies, varoval pred naprosto zbytečným nárůstem napětí, závody ve zbrojení, nástupem aliančních vzorců a modelů, které budou vydávány za důkaz agresivních záměrů Ruska a správnosti expanze NATO. Hovořil i o nebezpečí studené války číslo II. Připomněl, že Rusové vyklidili všechny své vojenské základny ve střední a východní Evropě, zatímco USA své základny v západní Evropě pouze zredukovaly. Přijetí tří nových zemí do NATO označil za výraznou nerovnost, což si Rusové mohou vyložit jako provokaci. ${ }^{82}$ Výhrady západních akademiků proti procesu expanze NATO nakonec nejvýstižněji shrnul George Kennan, ${ }^{83}$ klasický realista, který už v roce 1997 napsal, že se jedná o nejzávažnější omyl USA po skončení studené války. 84

\section{GEORGE W. BUSH JAKO POLITICKÝ GARANT DRUHÉ VLNY ROZŠIŘOVÁNÍ NATO}

Nedlouho po OAF 1999 znovu svitla naděje na obnovení bezpečnostní spolupráce mezi USA a Ruskem. V obou metropolích byli noví prezidenti: George Bush ml. a Vladimir V.

77 Hartung, W. D. (1998): Welfare for weapons dealers: The hidden costs of the arms trade. New York: New School for Social Research, World Polcy Institute, March 1998.

78 Waltz, K. N. (2000): NATO expansion: A realist's view, op. cit., s. 36.

79 Hellmann, G. - Wolf, R. (1993): Neorealism, Neoliberal Institutionalism, and the Future of NATO. Security Studies, Vol. 3 (1), s. 3-43.

80 Waltz. K. N. (2000): NATO expansion: A realist's view, op. cit., s. 31-32.

81 Gaddis, J. L. (1998): History, grand strategy and NATO enlargement. Survival: Global Politics and Strategy, Vol, 40(1), s. 145-146.

82 Galtung, J. (1997): The Eastward NATO Expansion: The Beginning of Cold War II? COPRI.

83 Autor koncepce zadržování ze samého počátku studené války, v níž kladl hlavní důraz na nevojenské zadržování, které mělo být zakládáno především na politických, diplomatických a ekonomických nástrojích.

84 Kennan, G. (1997): A Fateful Error. The New York Times, 5. 2. 1997. 
Putin. Ten svému partnerovi po teroristických útocích 11. 9. 2001 poskytl velice cenné poznatky o situaci v Afghánistánu (Operation Enduring Freedom 2001) a dodal zbraně Severní alianci (dokonce i tanky), ${ }^{85}$ a ta pak velice rychle postupovala směrem na Kábul a drtila tálibánské vojenské jednotky. Zároveň s tím trvale sílil důraz na jednostranné prístupy. Bushova administrativa zahájila válku proti Iráku (Operation Iraqi Freedom 2003, OIF), přestože proti byly nejen Rusko a Čína, ale také Francie.

\subsection{Pobaltí jako nová severovýchodní hranice NATO}

A v době mezi OEF 2001 a OIF 2003 se konal Pražský summit NATO (18.-19. 10. 2002) a ten rozhodl o prijetí sedmi nových členských zemí s tím, že plnohodnotnými členy se stanou v březnu $2004{ }^{86}$ To byla dosud největší, nejrozsáhlejší a také nejvýznamnější vina rozšiřování v celých dosavadních dějinách NATO. Novými členy se staly tři pobaltské země (které dřive byly dokonce součástí SSSR), dále pak Slovensko, Bulharsko a Rumunsko jako dvě významné černomořské země (všechny tři země předtím byly součástí Varšavské smlouvy) a spolu s nimi i Slovinsko.

Všechny tři pobaltské státy jsou malé, v jejich ozbrojených silách slouží jen něco málo přes 25 tis. vojáků. Všechny tyto země svého cíle dosáhly poklidným způsobem. Ale z hlediska bezpečnostního jsou to velice důležité země. Především díky poloze $v$ jižní části Finského zálivu (Estonsko) a Baltského moře (Lotyško a Litva). V době míru tudy vede spousta tras ruského námořního obchodu. A v př́padě války na jejich pobřeží lze uskutečňovat vylod'ovací operace, což je strategicky důležité pro případ projekce síly do hloubky území Ruské federace. ${ }^{87}$ Dnes tvoři východní hranici NATO, která se vyznačuje vysokým stupněm vojenského napětí. Má přibližně stejnou délku jako hranice někdejší SRN se zeměmi Varšavské smlouvy, 88 ale s tím rozdílem, že je výsledkem posunu hranic NATO o tisíc km na východ směrem k západní ruské hranici. Pro USA je to další zvětšení strategické hloubky a navýšení zdrojů pro vnější vyvažování. Pro nové členské státy je velkým přínosem proto, že dostaly bezpečnostní záruky proti zemi, kterou ve větším či menším rozsahu považovaly za bezpečnostní hrozbu.

85 O'Flynn, K. (2001): Russia in multi-million arms deal with Northern Alliance. Moscow gives major backing to opposition forces. The Guardian.com, 23. 10. 2001.

Dostupné na: https://www.theguardian.com/world/2001/oct/23/afghanistan.russia.

86 NATO. Official text: Prague Summit Declaration issued by the Heads. Dostupné na: https://www.nato.int/ cps/en/natohq/official_texts_19552.htm.

87 A s tím také počítají doktrinální dokumenty USA z posledních let.

88 Shlapak, D. A.-Johnson. M. W. (2016): Reinforcing Deterrence on NATO's Eastern Flank. Wargaming the Defense of the Baltics. RAND Corporation, 30. 8. 2016 Dostupné na: https://www.rand.org/content/dam/ rand/pubs/research_reports/RR1200/RR1253/RAND_RR1253.pdf. 


\subsection{Vstup NATO do černomořské oblasti}

Ve stejné době do NATO vstoupily také Bulharsko (110 $994 \mathrm{~km}^{2}$ ) a Rumunsko (s rozlohou 238391 km² největší země v jihovýchodní Evropě, jež po dobu studené války tvořily nárazníkové pásmo). Výše vzpomínaný S. Walt to vyhodnotil slovy, že mezi Ruskem a Západem nastal „geopolitický konflikt“. ${ }^{89}$ Nedílně s tím poklesly početní stavy ruských ozbrojených sil a trvale se zvyšovalo jejich kvalitativní zaostávání za USA a dalšími předními státy NATO. Ministr obrany USA Robert Gates v roce 2009 otevřeně přiznal, že ruské vojenské námořnictvo je jen stínem toho, co bývalo námořnictvo někdejšího SSSR, a že navíc námořnictvo USA je silnější nežli námořní vojenské síly dalších 13 států (včetně Ruska a Číny) dohromady. ${ }^{90}$

Při zdůvodňování rozšiřování NATO do oblasti Černého moře se zdůrazňovalo, že tato oblast se stala tzv. nebezpečným obloukem nestability zahrnujícím důležitou trasu organizovaného zločinu, zejména pašování drog a zbraní, obchodování s lidmi, aktivit teroristických organizací a popř. i pašování jaderných materiálů. Generální tajemník NATO v červnu 2004 použil stejné argumenty jako tři roky předtím v př́padě Afghánistánu. ${ }^{91}$ Vyhlásil, že pokud se NATO nezaměři na tyto hrozby a rizika, dokud jsou ještě od něho vzdálené, pak se stane, že jednoho dne je bude mít u svých dveří. ${ }^{92} \mathrm{~V}$ obou prípadech se navazovalo na strategii přední obrany, ale tentokrát budovanou ještě mnohem dál na východ. ${ }^{93}$

Z hlediska geo-ekonomického tvoří černomořská oblast střed osy spojující tři strategické zóny celosvětového významu. Na východě to je Kaspická oblast s bohatými zdroji ropy a zemního plynu, zatímco na západě to je oblast Středomoří, strategicky důležitá pro přistup do oblasti Středního východu a severní Afriky (Middle East and North Africe, MENA) a dále na západ do Atlantiku. Černé moře je tedy středem oblasti, které francouzští specialisté na geopolitiku říkají „tri-maritimité“, tedy uskupení tří moří, ${ }^{94}$ strategicky důležitých námořních cest. ${ }^{95}$ Výrazně stoupl význam ozbrojených sil této oblasti při zajištění plynulosti surovinových dodávek. ${ }^{96}$

89 Black, E. (2014): Stephen Walt and a "realist" take on NATO membership for Ukraine. MINNPOST, 26. 3. 2014.

90 Gates, R. (2009): A Balanced Strategy. Reprogramming the Pentagon for a New Age. Foreign Affairs, Vol. 88 (1), January/February 2009, s. 32.

91 Tehdy vyhlásil, že pokud NATO nebude v Afghánistánu, pak tamní teroristé jednoho dne přijdou do Paříže, Amsterdamu a Bruselu.

92 de Hoop Scheffer, J. (2004): NATO's Istanbul Summit: New Mission, New Means. Speech at the Royal United Services Institute, 18. 6. 2004.

93 Freedman, L. (1990): Iraq, Liberal Wars and Illiberal Containment. Survival, Vol. 48 (4), s. 52.

94 Gallois, P. (1990): Géopolitique, les voies de la puissance. Paris: Plon.

95 Chauprade, A. - Thual, F. (1999): Dictionnaire de géopolitique: États, Concepts, Auteurs. Paris: Éditions Ellipses,'s. 547.

96 Petersen, A. (2004): Black Sea Security: The NATO Imperative. Wilson Center. Global Europe Program, 20. 8. 2004. Dostupné na: https://www.wilsoncenter.org/publication/ black-sea-security-the-nato-imperative. 
Velmi důležitá je vojenská síla nových členských států NATO, zejména pak jejich vzdušných sil. ${ }^{97}$ Velký význam mají i námořní základny v obou černomořských zemích. Během operace Iraqi Freedom byla rozsáhle využívána rumunská základna Constanza ${ }^{98}$ a bulharská základna Sarafovo. Jejich nenahraditelný význam pro NATO již konci července 2004 vysoce ocenil i generál Richard B. Myers, předseda Sboru náčelníků štábů ozbrojených sil USA v letech 2001-2005. ${ }^{99}$ Obě tyto země poskytly plná práva na přelet nad vlastním územím $v$ době vedení válek $v$ Afghánistánu a v Iráku a významně se zapojily do misí NATO. ${ }^{100}$ Později se často psalo i o skandálu okolo využívání rumunské základny Constanza pro potřeby $\mathrm{CIA}{ }^{101}$

\section{Využití rumunských základen během OIF 2003}

Velkým přínosem pro NATO je budování protiraketových základen. Obě černomořské země tento záměr oficiálně vyhlásily již na počátku roku 2010. ${ }^{102}$ Důležitá jednání tam vedli zejména admirál James Stavridis na konci dubna 2010 a také tehdejší generální tajemník NATO Anders Fogh Rasmussen v květnu téhož roku. ${ }^{103}$ Po jejich skončení rumunský ministr obrany Gabriel Oprea sdělil, že vybudování protiraketového štítu bude příspěvkem jeho země $\mathrm{k}$ bezpečnosti celé Aliance. ${ }^{104} \mathrm{~A}$ posléze bulharský ministr zahraničních věcí Nikolaj Mladenov vyhlásil, že rozmístění těchto systémů má vazbu nejen na článek č. 5, ale na zahrnutí celé této oblasti do širšího rámce energetické bezpečnosti na předělu dvou významných světadílů. ${ }^{105}$ Do nové etapy se celý tento proces dostal 18. 12. 2015 oficiálním oznámením, že systém U. S. Aegis Ashore Missile Defense System Romania dosáhl předoperační fáze. ${ }^{106} \mathrm{Na}$ základně Deveselu už byly instalovány všechny tři složky včetně rízených střel a operačního stupně bylo dosaženo v roce $2015 .{ }^{107}$

A v neposlední řadě se potvrdilo, že nové členské státy jsou spolu s Tureckem strategicky významnými základnami pro projekci síly z Černomoří do krizových oblastí na východ, jihovýchod a jih od stávajících hranic NATO. Proto USA rozsáhle investovaly do

97 M.K. Air Base - US Army Europe. Dostupné na: https://www.eur.army.mil/21tsc/MKAB/about.html.

98 U.S. Base Commander Says Romanian Airport Used as „Bridgeheat” to Qatar and Bulgarian Government Offers U.S. Decommissioned Air Base. Radio Free Europe/Radio Liberty, 14. 3. 2003, Vol. 7. No. 49.

99 Petersen, A. (2004): Black Sea Security: The NATO Imperative, op. cit.

100 Konoplyov, S. (ed.) (2004): Harvard Black Sea Security Program 2003. John F. Kennedy School of Government, Harvard University.

101 Associated Press (2006): Romania „unsure on CIA flights“. The Guardian, 9. 2. 2006.

102 Rozoff, R. (2010): U.S. And NATO Accelerate Military Build-Up In Black Sea Region. Global Research, Vol, 21 (5).

103 Standart News, 16. 5. 2010.

104 The Financiarul, 14. 5. 2010.

105 Focus News Agency, 20. 5. 2010.

106 Dostupné na: https://www.defenseindustrydaily.com/sm-3-bmd-04986/, 22. 12. 2015.

107 Dostupné na: https://www.globalsecurity.org/space/facility/deveselu.htm. 
modernizace leteckých a námořních základen na území obou černomořských států NATO. ${ }^{108} \mathrm{Na}$ to pak navázala společná cvičení typu Black Sea Rotational Force, ${ }^{109}$ které po dobu tří měsíců probíhala na rumunské letecké základně Mihail Kogalniceanu, nebo společné cvičení 6 . americké flotily a jednotek vojenského námořnictva Rumunska, Bulharska a Gruzie, jež zahájila tradici cvičení tohoto typu i pro další roky. ${ }^{110}$

\subsection{NATO na Jadranu}

Po vstupu NATO do Pobaltí a do Černomoří přišly ještě tři další vlny rozšiřování, ale ty již byly mnohem méně rozsáhlé. $V$ dubnu 2009 do NATO vstoupily Albánie a Chorvatsko, po nich v červnu 2017 následovala Černá Hora a pomyslný kruh se uzavřel v březnu 2020 príjetím Severní Makedonie. Toto rozšíření nevyvolalo žádnou vážnou kontroverzi. Z hlediska geografického šlo o malé země $s$ celkovou rozlohou necelých $145000 \mathrm{~km}^{2}$ a s počtem necelých 12 mil. obyvatel. Navíc se tyto země nacházejí daleko od západní hranice Ruska a nemají žádné vojenské základny, ze kterých by RF měla bezpečnostní obavy.

Ve všech oblastech, tedy ve V4, v Pobaltí, v Černomoří a na Jadranu NATO a zejména pak USA jeho hegemon využily neobyčejně přiznivé situace $k$ jejich přeměně v pilíre svého vnějšího vyvažování. Při hodnocení této situace dva přední američtí autoři napsali, že po skončení studené války nastala situace, kdy SSSR předvedl „bezobdobný geopolitický ústup, ${ }^{111}$ ale následovaly vlny rozšíření NATO, které se staly ojedinělou ukázkou prosazení geopolitických zájmů“. ${ }^{112}$ Území NATO se rozšírilo o 1,2 mil. km2, jeho strategická hloubka se protáhla o více než 1 mil. km2 směrem na východ. To vše pak mělo zásadní dopad na uvažování ruských elit.

108 Bulgaria, Romania:US, NATOBasesforWarInTheEast.Novinite.com,26.10.2009. Dostupnéna:https://www. novinite.com/articles/109267/Bulgaria\%2C+Romania\%3A+US\%2C+NATO+Bases+for+War+In+The+East.

109 Cautious and rotational - US military engagement on NATO's eastern flank. OSW, 5. 7. 2016.

Dostupné na: https:// https://www.osw.waw.pl/en/publikacje/osw-commentary/2016-07-05/ cautious-and-rotational-us-military-engagement-natos-eastern.

110 Rozoff, R. (2010): U.S. And NATO Accelerate Military Build-Up In Black Sea Region, cit. op.

111 Deudney, D. - Ikenberry, G. J. (2009-2010): The Unravelling of the Cold War Settlement, op. cit.

112 Ikenberry, G. J: (2014):The Illusion of Geopolitics: The Enduring Power of the Liberal Order. Foreign Affairs, Vol. 93 (3), May/June 2014, s. 80-90. 


\section{RUSKÉ VYVAŽOVÁNÍ TVÁŘí V TVÁŘ EXPANZI NATO}

V Rusku od první vIny rozšiřování NATO sílil pocit, že Západ byl pokrytecký a nepřátelský, ${ }^{113}$ že nebral ohledy na ruské zájmy a názory. ${ }^{114}$ Tento pocit sílil již od Jelcinova projevu na vrcholné schůzce OBSE v Budapešti na konci roku 1994, v němž mluvil o posunu od bezpečnostní spolupráce ke studenému míru, ${ }^{115}$ což byl počátek ruských obav, že budou doplácet na výsledek studené války. ${ }^{116}$ Jelcinův projev odrážel komplex oslabené bývalé supervelmoci, že čím více se zmenšuje její rozloha a celková síla, tím více je obklopována sférou amerického vlivu. ${ }^{117}$ A to tím spíše, že počínaje druhou polovinou devadesátých let USA a jejich spojenci prestali brát ohledy na nostalgii ruských elit po někdejším statutu supervelmoci. ${ }^{118} \mathrm{~V}$ důsledku tzv. asymetrického konce studené války bylo Rusko na Západě hodnoceno jako príliš slabé a okrajové, a tak se mezi jeho elitami šiřil pocit tzv. výmarského syndromu země, jejíž důstojnost a zájmy byly ignorovány. ${ }^{119}$

Ruská federace ztratila bývalou strategickou hloubku. ${ }^{120}$ Rovnováha bezpečnostních hrozeb se vychýlila výrazně v ruský neprospěch. Nemá žádné možnosti vnějšího vyvažování, musí se spoléhat výlučně na vnitřní vyvažování. Zásadní změny přišly až na počátku 21. století, po nástupu V. Putina a prosazení Vládního plánu na vyzbrojování, který předpokládá zavádění nových tanků, obrněných vozidel, dělostřeleckých systémů, ale také raket odpalovaných ze země či z moře. ${ }^{121}$ Ruská federace začala hledat alternativní strategie, a těmi se staly zejména hybridní válka a posilování A2/AD (Anti-Access/Area Denia/122) schopností. ${ }^{123}$

113 Braithwaite, R. (2014): Russia, Ukraine and the West. The RUSI Journal, Vol. 159 (2). View further author information

114 Walker, E. (2015): Between East \& West: NATO Enlargement \& the Geopolitics of the Ukraine Crisis. E-International Relations, 13. 4. 2015. Dostupné na: https://www.e-ir.info/2015/04/13/ between-east-west-nato-enlargement-the-geopolitics-of-the-ukraine-crisis/.

115 Broader NATO May Bring „Cold Peace“, Yeltsin Warns: Europe. Dostupné na: https://www. articles.latimes.com/1994-12-06/news/mn-5629_1_cold-war.

116 Sakwa, R. (2007): Russia Against the Rest. The Post-Cold War Crisis of World Order. Cambridge: Cambridge University Press.

117 Parry, R. (2015): „Realists“ Warn Against Ukraine Escalation, 10. 2. 2015. Dostupné na: https://truthout. org/articles/realists-warn-against-ukraine-escalation/.

118 Krastev, I. - Leonard, M. (2015): Europe's Shattered Dream of Order. How Putin Is Disrupting the Atlantic Alliance. Foreign Affairs, Vol. 94 (3), s. 48-58.

119 Sakwa, R. (2015): The death of Europe? Richard Sakwa looks at continental fates after Ukraine. International Affairs, Vol. 91 (3), May 2015, s. 553-579.

120 Ta měla neocenitelný a nenahraditelný význam, což nejvýrazněji vyniklo během druhé světové války.

121 Klein, M. (2016): Russia's military: on the rise? Transatlantic academy Paper series, No. 2, 2016, s. 11-12.

122 Jsou to zbraňové systémy, které mají ozbrojeným silám USA bránit v tom, aby pronikaly do oblastí daleko od území USA, a které jim mají znemožňovat, aby tam uskutečňovaly vylod'ovací průlomové operace a aby zasazovaly údery do hloubky území, na něž mají proniknout.

123 Fruhling, S. - Lasconjarias, G. (2016): NATO, A2/AD and the Kaliningrad Challenge. Survival: Global Politics and Strategy, Vol. 58(2), s. 95-116. 
První ruská vojenská reakce na postup NATO směrem $\mathrm{k}$ jejím hranicím přišla v srpnu 2008. Této tzv. pětidenní válce předcházela ruská politika masového přidělování ruského občanství obyvatelům Jižní Osetie, ${ }^{124}$ což někteří západní odborníci označili za akt agrese. ${ }^{125}$ Potom následoval Saakašviliho neuvážený vojenský výpad proti RF, a tak se dodnes diskutuje, jak vážné chyby se gruzínský prezident dopustil. Tak např. tehdejší ministryně zahraničních věcí USA Condoleezza Rice uznala, že Michail Saakašvili se skutečně nechal vyprovokovat, ale dodala, že vinu za tuto válku nenese on, nýbrž ruská strana, která trvale stupňovala vojenský nátlak.

Na odražení gruzínského vojenského výpadu byla RF důkladně připravena, především díky předcházejícímu cvičení Kavkaz 2008. Nasadila jednotky 58. armády ze Severokavkazského vojenského okruhu, jmenovitě to byly 19. a 42. motostřelecká divize a 7. a 76. vzdušně výsadková divize. Nasazena byla i Černomořská flotila, jež přepravovala výsadkové jednotky a zároveň s tím blokovala oba dva gruzínské přistavy. ${ }^{126}$ Významným útočným systémem bylo vylod'ovací plavidlo Cesar Kunikov. ${ }^{127}$ Navíc RF rozmístila své jednotky na území dvou separatistických území, čímž získala dvě nové námořní základny pro Černomořskou flotilu a jednu novou leteckou základnu.

Od té doby nejvyšší činitelé USA a NATO vytýkají Rusku přehnaný strach a nadměrnou ctižádost, řinčení zbraněmi, agresivní modernizaci zbraní (jaderných i konvenčních) jakož i doktrín, pořádání velkých vojenských cvičení, zejména v oblasti Baltského moře, a zastrašování svých západních sousedů. ${ }^{128}$ Největší obavy na Západě vyvolává Západní vojenský okruh (ZVO) s velitelstvím v Petrohradu. Byl vytvořen v roce 2010 rozkazem prezidenta Putina, ${ }^{129}$ má jednu gardovou tankovou armádu, dvě motorizované brigády, dvě flotily vojenského námořnictva, armádu námořní pěchoty, několik vzdušně výsadkových divizí a řadu specializovaných brigád a útvarů. ${ }^{130}$ Je to mimořádně silné bojové uskupení, jehož prvním velitelem byl generálplukovník Valerij V. Gerasimov, nejzkušenější ruský generál, kterého v roce 2012 prezident V. Putin osobně vybral do funkce náčelníka generálního štábu Ruských ozbrojených sil a povýšil ho do hodnosti armádního generála.

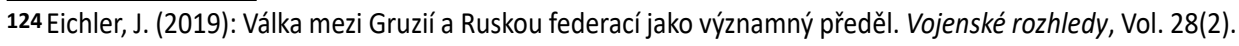

125 Natoli, K. (2010): Weaponizing Nationality: An Analysis Of Russia's Passport Policy In Georgia. Boston University International Law Journal, Vol. 28. Dostupné na: https://www.bu.edu/law/journals-archive/ international/documents/natoli_weaponizingnationality.pdf www.

126 Military Balance 2009, s. 212.

127 Felgenhauer, P. (2008): Russian Railroad Troops Complete Mission in Abkhazia. Eurasia Daily Monitor, Vol. 5 (114), 31. 7. 2008; Muchin, V (2008): V armii: Voennoekonomicheskie manévry. Nezavisimaia Gazeta, 4 8. 2008. Dostupné na: http://www.ng.ru/week/2008-08-04/7_army.html; Shanker, T. (2008): Russians Melded Old-School Blitz With Modern Military Tactics. The New York Times, 16. 8. 2008. Dostupné na: https://www.nytimes.com/2008/08/17/world/europe/17military.html.

128 Carter, A. (2016-2017): A Strong and Balanced Approach to Russia. Survival: Global Politics and Strategy, Vol. 58(6), December 2016-January 2017, s. 55-56.

129 Указ Президента Российской Федерации от 20 сентября 2010 года № 1144 "О военноадминистративном делении Российской Федерации».

130 The Military Balance 2017. Chapter 5: Russia and Eurasia. 
Západní vojenský okruh je bezesporu mnohem silnější a údernější nežli jednotky Polska a tří pobaltských zemí NATO. Ale ruští operativní realisté namítají, ${ }^{131}$ že jeho poslání se neomezuje jen na čtyři výše jmenované země, ale především na odpor vojskům, která by se mohla vylodit v Baltském a v Černém moři s cílem uskutečňovat tzv. průlomové operace a zasazovat údery do hloubky ruského území, ${ }^{132}$ jež ruští generálové považují za nanejvýš naléhavou bezpečnostní hrozbu pro svoji zemi. ${ }^{133} \mathrm{~A}$ tak se tato část Evropy stala svědkem střetu dvou nesmiřitelných interpretací dosavadního vývoje, přičemž každá strana hodnotí tytéž události zcela jinak. ${ }^{134}$

\section{RUSKÉ SYSTÉMY A2/AD}

Vojenskou reakcí na expanzi NATO se staly ruské zbraňové systémy souhrnně nazývané $A 2 / A D,{ }^{135}$ které jsou schopné bránit vojskům USA a jejich spojenců v plnění bojových úkolů daleko od svého území. ${ }^{136}$ Dávají možnost bránit silnému protivníkovi, který vojensky intervenuje daleko od svého území, aby na předpokládaném bojišti rozmístil svoje ozbrojené síly a aby je účinně rozvíjel do hloubky vytipovaného území. Případnému protivníkovi dávají možnost zmenšovat nadřazenost ozbrojených sil USA a držet je co nejdále od místa, ve kterém by měly ničit zadané cíle. Mohou intervenujícím vojskům způsobit vysoký stupeň opotřebování, nebo dokonce rozhodující porážku, v jejichž důsledku by USA ztratily politické odhodlání k tomu, aby cestou vojenské intervence podporovaly své spojence nacházející se daleko od jejich metropolitního území. ${ }^{137}$

Nejvyšší činitelé NATO tyto systémy označují za novou bezpečnostní hrozbu, a to zejména vůči svým novým členským státům. Zdůrazňují, že v reakci na ruské A2/AD je nutné zaujmout nové strategické postoje a př́stupy, zejména pak v oblasti Baltského a Černého moře. ${ }^{138}$ Závěrečné prohlášení Varšavského summitu NATO v roce 2016 Rusku

131 Создано новое стратегическое командование. Rossiyskaya Gazeta, 1. 12. 2014.

132 Khodarenok, M. (2015): Scenario for the Third World War [in Russian]. Voyenno-promyshlennyy kuryer, 18. 3. 2015. Dostupné na: http://vpk-news.ru/articles/24284.

133 Gerasimov, V. (2014): The World on the Verge of War [in Russian]. Voyenno-promyshlennyy kuryer, 15. 3. 2017. Dostupné na: http://vpk-news.ru/articles/35591; též viz Rogovoy, A. V. (2014): A Russian View of Land Power. Cambridge, UK: Conflict Studies Research Center, December 2014. Dostupné na: http://amzn.to/2mJCS8I.

134 Neumann, I. B. (2016): Russia's Europe, 1991-1996: Inferiority to Superiority. International Affairs, Vol. 92(6), s. 1381-1399.

135 Bliže viz Eichler, J. (2020): Americké vojenské doktríny nové generace. Vojenské rozhledy, Vol. 29(1), s. 3-9. Dostupné na: https://www.vojenskerozhledy.cz/kategorie-clanku/bezpecnostni-a-obranna-politika/ americke-vojenske-doktriny.

136 Tangredi, S. J. (2013): Anti-Access Warfare. Countering A2/AD Strategies. Annapolis: Naval Institute Press.

137 Krepinevich, A. F. (2010):CSBA:WhyAirSeaBattle?.CenterforStrategicand BudgetaryAssessments (CSBA). Dostupné na: https://csbaonline.org/uploads/documents/2010. 02. 19-Why-AirSeaBattle.pdf.

138 Sinan Ülgen, S. - Kasapoğlu, C. (2016): A Threat-Based Strategy for NATO's Southern Flank. Carnegie Europe, 10. 6. 2016. Dostupné na: https://carnegieendowment.org/files/NATO_Southern_Flank.pdf. 
tvrdě vytklo, že porušilo všechny hodnoty, zásady a závazky, na kterých byl již od roku 1977 postaven rámec vzájemných vztahů, ${ }^{139}$ přičemž podtrhlo zejména anexi Krymu a podporu separatistů ve východní Ukrajině. Madeleine Albright hovořila o nutnosti posunu od dosavadního ujištování nových členských zemí k důraznému odstrašování Rus$\mathrm{ka},{ }^{140}$ a proto navrhla dvě zásadní opatření. Prvním z nich je navýšení počtů ozbrojených sil NATO na území Polska a tří pobaltských zemí, druhým je vytvoření dvou nových velitelství, a to v Polsku a v Rumunsku. ${ }^{141}$ Prioritou se tak stalo vytvoření uskupení zvaného Very High Joint Readiness Task Force (VJTF), kterému se také říká Spearhead (na samém počátku to bylo 5000 vojáků pod velením V. Británie). ${ }^{\mathbf{1 4 2}}$ Tato opatření navázala na předcházející rozmístění systému Aegis ve španělské námořní základně Rota. ${ }^{143}$

\section{ZÁVĚR}

Pokud jde o první výzkumnou otázku tohoto článku, pohled z pozic neorealistické teorie ukazuje, že prvním zásadním mezníkem procesu rozšiřování NATO byl vstup do Pobaltí a do Černomoří. Dnes je NATO přítomno v rozsáhlé oblasti od Finského zálivu, přes Pobaltí, střední Evropu (ČR, SR, Mad'arsko) až po čtyři státy Jaderského moře. A zcela na jihu tuto oblast uzavírají dva významné státy z první vlny rozšiřování v roce 1952, jimiž jsou Řecko a Turecko, které kontroluje celou jižní část Černého moře. Rozloha NATO se po skončení studené války rozšírila o 1202200 km², žije zde více než 100 mil. obyvatel. NATO tak získalo novou strategickou hloubku. Velký strategický význam mají vojenské základny na území nových států, které mohou hrát rozhodující úlohu v případě vylod’ovacích operací a projekce síly do hloubky protivníkova území.

Ve světle všech výše uváděných změn se plně potvrdila náležitost neorealistického přístupu. Během posledních třiceti let se výrazně proměnila rovnováha bezpečnostních hrozeb, a to jednoznačně ve prospěch NATO, a zejména pak USA jako hegemona celé Aliance. USA mohou využívat, a několikrát to i učinily, velice rozsáhlé území svých nových spojeneckých zemí, mají k dispozici jejich vojenské a námořní základny a velmi důležitou úlohu hraje i velká vstřícnost a vděčnost politických a vojenských elit všech nových

139 Warsaw Summit Communiqué - Issued by the Heads of State and Government participating in the meeting of the North Atlantic Council in Warsaw 8-9 July 2016.

140 Golts, A. (2016): From Assurance to Deterrence: The Russia Question and NATO's Summit in Warsaw. Eurasia Daily Monitor, Vol. 13(124). Dostupné na: https://jamestown.org/program/ from-assurance-to-deterrence-the-russia-question-and-natos-summit-in-warsaw/.

141 Nato's Russia-deterrent force „fully operational“. EUobserver, 30. 6. 2017. Dostupné na: https:// euobserver.com/foreign/138399.

142 Lasconjarias, G. - Nagy. T. A. (2018): NATO Adaptation and A2/AD: Beyond the Military Implications. GLOBSEC, 26. 3. 2018. Dostupné na: https://www.globsec.org/publications/ nato-adaptation-a2ad-beyond-military-implications/.

143 Eckstein, M. (2015): BMD-Equipped Destroyer USS Porter Arrives in Rota, Spain. USNI News, 1. 4. 2015. Dostupné na: https://news.usni.org/2015/05/01/ bmd-equipped-destroyer-uss-porter-arrives-in-rota-spain. 
členských zemí, které si vysoce cení nově získaných bezpečnostních záruk a prijijetí do společenství sdílených hodnot. Naproti tomu RF je $v$ situaci, kdy musí spoléhat výlučně na vnitřní vyvažování, na svoje vlastní zdroje a síly. V současné Evropě nemá žádné oddané spojence a je odkázána výlučně na faktory své hard power, zatímco soft power, tedy síla př́ikladu a přitažlivosti, nikde navenek nefunguje.

Zcela nejzávažnějšími mezníky vývoje po skončení studené války se staly dvě války, kterými RF manifestovala svůj vojenský odpor proti záměrům na př́padné další rozširování NATO. Byly to tzv. pětidenní válka mezi Gruzií a Ruskem a zejména potom válka na východní Ukrajině a anexe Krymu na jaře roku 2014. V prípadě Krymu šlo především o vojenský prístav v Sevastopolu, který nemá nikde v Evropě obdoby, co se týká polohy, rozlohy, hloubky a strategického významu. ${ }^{144}$ Právě v této době vyvrcholily obavy politických a vojenských elit RF, že rozšiřování NATO je proces, jehož cestou Západ upevňuje svoje pozice a vliv na úkor jejich země. ${ }^{145}$

A ve světle třetí výzkumné otázky se ukazuje, že neorealistickému pojetí mezinárodní bezpečnosti, zejména pak kritériím vzdálenosti mezi kompetitory, útočných schopností jejich ozbrojených sil, rovnováhy hrozeb a jejich vnímání plně odpovídá také rozhodování a jednání ruských politických a vojenských elit. Přijetí tř́ pobaltských a dvou černomořských zemí (2004) a pozvánka pro Ukrajinu a Gruzii (Bukurešt 2008) vyvolaly v Rusku silné bezpečnostní obavy, které nakonec vyústily ve vybudování Západního vojenského okruhu v Petrohradě (2010) a zejména pak v anexi Krymu v roce 2014. Na tu posléze navázala operace Atlantic Resolve, a výsledkem se stalo další zkrácení vzdálenosti mezi jednotkami rozšířeného NATO na jedné straně a RF na druhé straně. Na hranici mezi NATO a Ruskem narůstá počet a závažnost vojenských incidentů, zvyšuje se vojenské napětí a stupňuji se bezpečnostní dilemata.

Aktivity ozbrojených sil RF jsou v NATO vnímány jako prověřování bojové pohotovosti Aliance, soudržnosti mezi jeho členskými státy, jako demonstrace ruské bojové pohotovosti a odhodlanosti postavit se jakýmkoli snahám o další rozšiřování NATO a přibližování jeho hranic směrem $k$ Moskvě. ${ }^{146} \mathrm{~V}$ důsledku dosavadního vývoje dnes existuje několik možných scénářu výbušných situací, které by nakonec mohly vyústit i v přímou ozbrojenou konfrontaci. ${ }^{147}$ Je to především trvalá eskalace napětí ve východní Ukrajině a nebezpečné vojenské incidenty v Baltském a Černém moři, jejichž základem jsou opakovaná narušování vzdušného prostoru a další prvky nezáměrných i záměrných eskalací. A v neposlední řadě je to možnost konfliktu mezi civilními a vojenskými letouny. ${ }^{148}$ Proces roz-

144 Mungo, M. (2017): Sevastopol's Wars: Crimea from Potemkin to Putins. Oxdord: Osprey Publishing, s. 67.

145 Sarotte, M. E. (2014): A Broken Promise? What the West really told Moscow about NATO expansion, op. cit.

146 Frear T. - Kulesa, L. - Kearns I (2014): Dangerous Brinkmanship: Close Military Encounters Between Russia and the West in 2014. European Leadership Network, November 2014.

147 Interactive Map of Russia-West Dangerous Military Encounters Updated, December 2014, and RussiaWest Dangerous Brinkmanship Continues, March 2015.

148 Kearns, I. (2015): Avoiding War in Europe: The Risks From NATO-Russian Close Military Encounters. Arms Control Association, 2. 11. 2015. Dostupné na: https://www.armscontrol.org/act/2015-11/features/ avoiding-war-europe-risks-nato-russian-close-military-encounters. 
šiřování NATO tedy má i svoji odvrácenou stranu, která potvrzuje rčení, že není růže bez trní. Na rozhraní mezi rozšířenou Aliancí na jedné straně a Ruskou federací na druhé straně se po druhé vině rozšíření NATO vytvořila nová železná opona, na jejíchž obou stranách proti sobě stojí velmi silná vojenská uskupení s mohutnou ničivou silou. Tu mají především jednotky ruského Západního vojenského okruhu. Hranice mezi NATO a Ruskem jako „sdílené sousedství 149 se stala prostorem narůstajícího vzájemného napětí, kde se stupňuje vojenské soupeření dvou protikladných hodnocení. ${ }^{150} \mathrm{Z}$ toho vyplývá hlavní výzva pro obě strany: nastolit spolehlivý systém vzájemné komunikace a postupů směřujících k snižování potenciálu bezpečnostních rizik, aby současné napětí v Evropě nepřerostlo $v$ horký konflikt. ${ }^{151}$ Cílem je návrat $k$ bezpečnostní spolupráci, jejíz příklad dali v letech 1985-1990 Michail Gorbačov a Ronald Reagan. ${ }^{152}$ Dnešní Evropa tedy nečeká na nového Godota, ale čeká na nového Reagana a na nového Gorbačova. Ve hře je opravdu hodně.

Tento článek byl zpracován v rámci grantového projektu TA ČR Migrace z oblasti Blizkého východu, subsaharské Afriky a Asie: geopolitické a bezpečnostni souvislosti, důsledky a doporučení pro ČR. Identifikační kód projektu (číslo): TL01000432.

\section{SEZNAM ZKRATEK}

\begin{tabular}{|l|l|}
\hline A2/AD & Area Access/Anti Denial \\
\hline AN & analytic narrative \\
\hline CFE & Conventional Armed Forces in Europe \\
\hline ČR & Česká republika \\
\hline MENA & Middle East and North Africa \\
\hline NATO & North Atlantic Treaty Organization \\
\hline NLA NDR & Národní lidová armáda Německé demokratické republiky \\
\hline NSC & National Security Council (USA) \\
\hline OAF 1999 & Operation Allied Force \\
\hline OIF 2001 & Operation Enduring Freedom 2001 \\
\hline OIF 2003 & Operation Iraqi Freedom 2003 \\
\hline OBSE & Organizace pro bezpečnost a spolupráci v Evropě \\
\hline PfP & Partnership for Peace \\
\hline RF & Ruská federace \\
\hline SR & Slovenská republika \\
\hline
\end{tabular}

149 Tento nový pojem zavedl European Leadership Network (ELN), což je celoevropský think-tank, který se zabývá otázkami zahraniční, obranné a bezpečnostní politiky. Sídlí v Londýně. Sdružuje odborníky nejen ze zemí EU, ale také z Ruska, Ukrajiny, Gruzie, Turecka, Albánie, Norska a Srbska.

150 Frear, T. - Kearns, I. (201T): Defusing future crises in the shared neighbourhood. Can a clash between the West and Russia be prevented? European Leadership Network, 27. 3. 2017. Dostupné na: https://www.europeanleadershipnetwork.org/policy-brief/defusing-future-crises-in-theshared-neighbourhood-can-a-clash-between-the-west-and-russia-be-prevented/.

151 Sokolski, R. (2017): The New NATO-Russia Military Balance: Implications for European Security. Task Force White Paper. Carnegie Endowment for International Peace, 13. 3. 2017.

152 Open Letter to President Donald Trump and President Vladimir Putin, 27. 6. 2017 Dostupné na: https://www. europeanleadershipnetwork.org/wp-content/uploads/2017/10/Letter-to-Trump-and-Putin_Embargoed. 


\begin{tabular}{|l|l|}
\hline SSSR & Svaz sovětských socialistických republik \\
\hline START & Strategic Arms Reduction Treaty \\
\hline USA & United States of America \\
\hline VJTF & Very High Joint Readiness Task Force \\
\hline ZVO & Západní vojenský okruh (Petrohrad) \\
\hline
\end{tabular}

Autor:

Doc. PhDr. Jan Eichler, CSc., narozen v roce 1952. Je absolventem Vojenské politické akademie v Bratislavě (1974). V minulosti byl zástupcem vedoucího odboru na Institutu pro strategická studia Ministerstva obrany (1991-1993), působil v Generálním štábu Československé armády (1990-1991) a na Ministerstvu obrany ČSSR (1982-1990). V roce 1985 obhájil disertační práci (CSc.) a v roce 2004 obhájil habilitační práci (Doc.). Působí jako seniorní výzkumný pracovník Centra evropské politiky Ústavu mezinárodních vztahů v Praze. Kromě toho vyučuje na Fakultě mezinárodních vztahů Vysoké školy ekonomické v Praze. Předmětem jeho odborného zájmu jsou transatlantické vztahy, strategická kultura, války v dnešním světě a terorismus. Je členem oborové rady doktorského studia FSV UK, MUP Praha a FBMI ČVUT na Kladně. Je autorem dvou monografií v anglickém jazyce, šesti monografií v českém jazyce a rady odborných článků v domácích i zahraničních časopisech (Francie, USA, Velká Británie, SRN).

Jak citovat: EICHLER Jan. NATO po skončení studené války. Vojenské rozhledy. 2021, 30 (2), 003-025. ISSN 1210-3292 (print), 2336-2995 (on-line). Available at: www.vojenskerozhledy.cz. 


\section{Martial Virtues and Whistle-Blowing: Loyalty Misplaced and Courage Misunderstood}

\section{Bojové ctnosti a whistleblowing: ztracená věrnost a nepochopená odvaha}

\section{Dragan Stanar}

Abstract: This paper aims to explain the tension between the phenomenon of whistle-blowing and military values, embodied in core martial virtues of loyalty and courage, which are integral in all armies. By defining these virtues in the military context, the author demonstrates how expressing dissent in the military is not necessarily opposed to loyalty and courage, but rather that it is necessary if conflict of different loyalties is properly managed and if courage is properly understood. Only by ensuring that armed forces are led by those who truly understand military values and martial virtues, and that whistle-blowing can be both patriotic and heroic, can we strive for a lasting peace. By courageously expressing loyalty to his nation, institution and profession, a soldier may act heroically by blowing the proverbial whistle.

Abstrakt: Cílem této práce článku je vysvětlit napětí mezi fenoménem whistleblowingu a vojenskými hodnotami ztělesněnými v základních bojových ctnostech věrnosti a odvahy, které jsou nedílnou součástí všech armád. Definováním těchto ctností ve vojenském kontextu autor ukazuje, že vyjádření nesouhlasu $v$ armádě nemusí nutně odporovat věrnosti a odvaze, je však především nutné, aby byl konflikt rozdílných loajalit přiměěeně zvládnut a odvaha správně pochopena. Pouze při zajištění, že ozbrojené síly budou vedeny těmi, kdo skutečně chápou vojenské hodnoty a bojové ctnosti a také to, že whistleblowing může být vlastenecký i hrdinský, můžeme usilovat o trvalý mír. Odvážným vyjádřením věrnosti svému národu, instituci a profesi může voják hrdinsky jednat i tehdy, když zapíská na př́ślovečnou píštalku.

Key words: Whistle-Blowing; Military; Virtues; Courage; Loyalty.

Klíčová slova: Whistleblowing; armáda; ctnosti; odvaha; věrnost. 


\section{INTRODUCTION}

Topic of virtues has been present in moral philosophy since its beginnings. The notion of virtue derives from the Latin term Virtus, meaning excellence or capacity, and signifies "a disposition or a pattern in someone's character or personality that leads them to act morally"1. Virtues are admirable traits, cornerstones of moral character. Virtues were at the focus of interest of many ancient philosophers, especially Greek philosophers who attempted to define and develop $\alpha \rho \varepsilon \eta^{2}$. Development of virtues and their role in life represent the foundation of a normative ethical theory that we call Virtue ethics. Virtue ethics gradually gave way to deontological and utilitarian theories, but re-emerged as a significant factor in the $20^{\text {th }}$ century moral philosophy with authors like Foot, Maclntyre, Anscombe, etc. Despite the virtue ethics comeback normative theories of duty and utility are still predominant in moral philosophy. Nevertheless, virtue ethics has been essential in one particular area of ethics - military ethics. Following Aristoteles's ideas, "military ethical training emphasizes formation of strong moral character rather than sets of rules"3. There seems to be virtually no military ethics curriculum without significant sections regarding virtue development, with more than a few of them entirely based on virtues as "most of today's militaries put their money on character building in trying to make their soldiers, airmen, sailors, and marines virtuous" ${ }^{4}$. Military virtues are integral to military profession, and their development is one of the highest-order tasks of military training.

The phenomenon of organizational dissent in social institutions has become an interesting ethical problem, but it seems that dissent poses an unparalleled ethical problem when expressed in the military. This is quite expected, given the fact that the nature and role of the military is also unparalleled in society. But how does dissent relate to virtues, that are central to military identity? The military represents "one of the most powerful and most cohesive moral communities in modern society, precisely because its members as individuals identify primarily as members of an army... military virtues are a part of these personal identities" ${ }^{\prime 2}$, meaning that they transcend professional virtues of an organization. Is dissent even compatible with martial virtues, carefully instilled and developed in soldiers by their organizations? Is it even compatible with the military itself? The reason that got us interested in exploring this relationship between dissent and military virtues are the attitudes expressed by senior-year Military Academy cadets, generation after generation, country to country, whenever dissent and whistle-blowing in

1 Van Hoof, S. Understanding Virtue Ethics. Slough: Acumen Publishing Limited, 2006, p.1.

2 Notion of ápєtń was central in Greek philosophy, signifying all forms of excellence.

3 Schulte, P. Morality and War. In: J. Lindley-French and Y. Boyer (ed.). The Oxford Handbook of War. Oxford: OUP, 2012, p. 110.

4 Olsthoorn, P. Military Ethics and Virtues. London: Routledge, 2011, p. 4.

5 Фатић, А. Савремена технологија ратовања у светлу хришћанског морала. In Б. Гроздић (ed.). Православље и рат. Београд: МЦ Одбрана, 2017, р. 120. 
the military are discussed ${ }^{6}$. It is not just the fact that the majority of cadets frown upon whistle-blowers and strongly disapprove of their actions that is curious, but the fact that they allude to military virtues as their arguments in these discussions, particularly the virtues of loyalty and courage. These two are precisely the military virtues that are continuously being instilled in them from the moment they enter the system, and that will continue to be nurtured by the military as long as they are a part of it. Such attitudes are not solely reserved for cadets, rather they are shared by officers, NCOs and soldiers. The perception of dissent and whistle-blowing in the military has everything to do with how virtues of loyalty and courage are understood by those who are proud to call themselves soldiers ${ }^{7}$. Are we creating such a paradoxical narrative in which military virtues of loyalty and courage are actually preventing soldiers from doing the morally right thing? Are they understanding the virtue of courage properly, and to whom are they taught to be loyal?

\section{LOYALTY AND COURAGE}

Virtues of courage and loyalty are present in ethical codes, lists of values, codes of conduct, soldier's creeds, and similar documents of all modern militaries - "Not surprisingly, it is this virtue of courage that figures, together with loyalty and honour, prominently on the lists of virtues and values of most armed forces" 8 . The two are present in The Army Values ${ }^{9}$ of the US Army, in the Department of the Navy Core Values Charter ${ }^{10}$, in the Values and Standards of the British Army, in the Code of Honor ${ }^{\mathbf{1 1}}$ of the Serbian Armed Forces, etc. Mompeyssin published a comparative study in 2014, in which he compared documents regarding soldiers' codes of conduct from 17 militaries. One of the "many common points"12 in these documents is the presence of courage and loyalty. Another comparative study ${ }^{13}$, published a year later revealed the same as they went through the codes of British, Canadian, German, Dutch, Russian, French, Spanish, Portuguese, and American militaries. Courage and loyalty are cornerstones of all modern

6 After speaking and corresponding with numerous colleagues who teach ethics at different military academies, we found this phenomenon to be inherent to all militaries.

7 We use the term soldier to signify all those serving in military uniforms.

8 Olsthoorn, P. Military Ethics and Virtues, p. 44.

9 US Army. The Army Values. [viewed date: January 20th, 2021] available at: https://www.army.mil/ values/

10 In this Charter, loyalty is actually listed as a manifestation of courage, something that is quite interesting for our topic. US Navy. Navy Core Values Charter. [viewed date: January $20^{\text {th }}, 2021$ ] Available at: https:// www.secnav.navy.mil/Ethics/Pages/corevaluescharter.aspx

11 Serbian Armed Forces. The Code of Honor. [viewed date: December $11^{\text {th }}, 2020$ ] available at: http://www. mod.gov.rs/multimedia/file/staticki_sadrzaj/tradicija/2020/Kodeks_casti_pripadnika_VS.pdf

12 Mompeyssin, P. Soldier's codes of conduct in different countries around the world. Journal of Defense Resources Management. 2014, (5), p.6.

13 Bouzid, H. et al. Toward a European code of conduct for military and peacekeeping forces. In G. Lucas (ed.). Routledge Handbook of Military Ethics. London: Routledge, 2015, p. 194-207. 
military ethical codes, as "these are the twin virtues that form the core of military honour, from which the other virtues (obedience, integrity, honesty) are derived"14. But it is not just military organizations that rely on these two core values, they are likely to have been ever-present in military culture since the first warriors. In her book The Code of the Warrior ${ }^{15}$, French takes us on a journey from ancient Greece and Rome across the Vikings and Native Americans to Chinese warriors and Samurai, in an attempt to separate warriors from murderers and soldiers from killers using the warrior's code. We see that courage and loyalty were essential martial virtues for warriors from all eras and all corners of the world. These two virtues are not "merely contingent, but also evolve organically from the nature of that (military) profession; loyalty and courage are not virtues or traits that might be replaced with any others. These traits are essential to being a member of the military; one cannot be a good member of the military and fulfil one's role without them"16.

\section{LEVELS OF LOYALTY}

All virtues have always been notoriously difficult to define. Opinions on loyalty differ greatly - from considering loyalty to be "not a virtue per se"17, to those perceiving it as a "virtue that is absolutely central to military service"18. The author of the latter formulation offers a definition of loyalty that is convenient and advantageous to our research - "Loyalty involves a willingness to bear risks and make sacrifices for the sake of that to which one is loyal"19, and we shall therefore use it in our analysis. In the context of dissent and whistle-blowing the crucial task is to identify to whom or to what a soldier is loyal, and see if dissent is an expression of disloyalty. The first level of loyalty in the military is the one without which "the military cannot function efficiently" 20 and the one that is most manifest in warrior ethos, warrior legends, the very essence of warrior culture - loyalty to one's unit, one's comrades. This is the primary understanding in military institutions, as it is necessary for successful integration, creating unit cohesion and forming a bond. We shall refer to this type of loyalty as "group loyalty". Being loyal to one's comrades and to one's superiors is perceived as a driving force behind all valour

14 Kaurin, P.M. The Warrior, Military Ethics and Contemporary Warfare: Achilles Goes Asymmetrical. London: Routledge Taylor and Francis Group, 2016, p. 40.

15 French, S.E. The Code of the Warrior: Exploring Warrior Values Past and Present. Lanham: Rowman and Littlefield Publishers, 2003.

16 Shanks-Kaurin, P. Questioning Military Professionalism. In N.K. Finney and T.O. Mayfield (ed.). Redefining the Modern Military. Annapolis: Naval Institute Press, 2018, p. 27.

17 Olsthoorn, P. Military Ethics and Virtues, p. 91.

18 Sparrow, R. War without Virtue. In B.J. Strawser (ed.). Killing by Remote Control: The Ethics of an Unmanned Military. Oxford: OUP, 2013, p. 90.

19 Ibid.

20 Kaurin, P.M. The Warrior, Military Ethics and Contemporary Warfare, p. 45. 
in the field, behind risking one's life and self-sacrifice. There is a common theme of the proverbial "band of brothers" in practically all war tales. What most soldiers later tell is that in the moment of the battle, when their lives are hanging on by a thinnest of threads and when the difference between life and death is often plain dumb luck, soldiers fight for their comrades, for the man next to them. This poetic bond between men in the field, forged by continual imminent danger and the so-called phenomenon of proximity to death, was perhaps most prominently and quite beautifully described by Shakespeare, in his acclaimed play Henry $V$, through the mouth of King Henry, who, in an attempt to encourage and embolden his troops before the battle, famously proclaimed "...We few, we happy few, we band of brothers; for he today that sheds his blood with me shall be my brother, be he ne'er so vile..." ${ }^{\mathbf{2 1}}$. Loyalty to one another is one of the key factors that keeps units from falling apart at the first sight of peril, and what keeps men pushing forward, as they know that their "brothers in arms" will not abandon them. Due to the pivotal roles that loyalty to fellow-soldiers and group cohesion play in all military operations, loyalty is accentuated on every level of military education and training. This level of loyalty has been the most important to the majority of soldiers in history. If we then place group loyalty in the previously mentioned definition, it would mean that loyalty implies willingness to bear risks and make sacrifices for the sake of the unit and comrades. Few would argue that there is anything wrong with such an understanding. But soldiers must be loyal to more than just their units and their commanders.

"Second level" loyalty demanded of every soldier is loyalty to the traditions and reputation of his profession. Not just to the tradition of the abstract idea of a soldier's profession, but to the tradition of a particular army, or even a particular unit - Marines (US Navy), Rangers (US Army), Cossacks (Russian Military), Gurkhas (British Army), Iron Regiment (Serbian Army), etc. These units are not necessarily elite or special forces units, but such units usually tend to take extra care to preserve their reputations and maximize group loyalty. Military organizations of many nations have centuries-long history and proud warrior traditions that have substantial impact on behaviour of their current members. Therefore, a nation's military history represents a significant factor, as “there is something more visceral about military history... history reminds people that they are part of something bigger and older than they are, in which those going before have set standards of conduct and behaviour that today's people are expected to keep up" 22 . Once an individual becomes a soldier, a member of a particular unit, he must respect and uphold the traditions and image of something that is older and greater than himself. Many a soldier before him has shed blood and laid his life down in heroic endeavours and such sacrifices are woven into the identity of his unit or army and it comes as no surprise that "the motivation for individual warriors to remain true to their code often comes from their desire not to betray the memory of the warriors who came before

21 Shakespear, W. Henry V. Jefferson City: American Book Company, 1914, p. 84.

22 Anglim, S. An Educated Military: Professional Education and the Profession of Arms. In N.K. Finney and T.O. Mayfield (ed.), Redefining the Modern Military: The Intersection of Profession and Ethics. Annapolis: Naval Institute Press, 2018, p. 164. 
them"23. We shall call this second level of loyalty to one's military institution - loyalty to warrior traditions or loyalty to profession. This type of loyalty may seem too distant and abstract for soldiers to grasp, but it has proven to be very important. French writes about a young Marine, shaken by deaths of his fellow Marines in Vietnam, who held a rifle at the head of a non-combatant. He only lowered his weapon when his officer told him "Marines don't do that" ${ }^{24}$, reminding him that his actions must be compatible with the proud traditions of US Marines. He was reminded of who he represents in his uniform. It is not just personal morality and warrior image that is being compromised in such cases, but also the identity of entire units or even armies. Again, it doesn't have to be loyalty to traditions of some special-forces unit, it can be loyalty to entire armies - we can easily imagine an officer saying - Serbian officers don't do that, Romanian soldiers don't do that, Czech warriors don't do that, and achieving the same effect.

Finally, the "third level" of loyalty signifies loyalty to one's society, or better formulated, to one's nation - "national loyalty". Purpose of a soldier must be to bring good to his nation via establishment or preservation of a lasting peace - "If understood as an institution whose goal is to maintain peace via deterrence, and to achieve peace via fighting against those who make peace impossible, then every army must subordinate its manner of fighting to the possibility of achieving peace"25. Soldiers' primary allegiance is to their nations and to a good, lasting peace. Much has been written in recent years about the role of soldiers in the quest for peace - soldiers, even lower-level non-commissioned officers, have been recognized as factors of peace, as "strategic corporals" $\mathbf{2 6}$, and their behaviour in war as crucial for the possibility of establishing lasting peace, instead of short-term truces. Armed forces are now instruments of creating peace, not just winning wars. By respecting the International humanitarian law and limits of Jus in Bello, soldiers pave the way for peace that will come. By doing so, they remain loyal to their society, which gave them the mandate to kill and injure in war, but only for the purpose of peace. Soldiers remain loyal only if they protect the sacred trust invested in them by their nations, i.e. only if they exercise their unique discretion ${ }^{\mathbf{2 7}}$ in the interest of their nation "the relationship of trust between the military and the state is based on an understanding that the military will employ its monopoly over the knowledge and skills to use force only in the furtherance of the interests of the nation.... The state trusts individual

23 French, S.E. The Code of the Warrior, p. 16.

24 Ibid. p. 14.

25 Stanar, D. Paramilitary organizations and private military companies in war: How to restrain what you do not control? In P. Mileham (ed.). Jus Post Bellum: Restraint, Stabilisation and Peace. Leiden: Brill Nijhoff, 2020, p. 362.

26 This notion was introduced by Krulak, who recognized that in modern warfare in-field decisions of soldiers can have strategic implications. Krulak, S, The Strategic Corporal: Leadership in the Three Block War. Marines Magazine, 1999, (1), p. 1-7.

27 Soldiers enjoy a fiduciary relationship with the state - "The exercise of discretion is also the hallmark of fiduciary relationships, where the principal allows the fiduciary to exercise discretion that affects the interests of the principal“" Brick, J. The Military Profession: Law, Ethics, and the Profession of Arms. In N.K. Finney and T.O. Mayfield (ed.). Redefining the Modern Military: The Intersection of Profession and Ethics. Annapolis: Naval Institute Press, 2018, p. 44. 
members of the military profession to use their expertise and to behave in a manner that is consistent with the interests of the state" 28 .

The interest of a nation is served if immoral and illegal behaviour within the military is prevented or reported. Of course, there are instances in which the decision not to report provides a tactical advantage; but on a strategic level, it is never in the interest of a nation to plant seeds of future conflicts.

There is also something that is called "loyalty to principle". We do not negate the existence of this level of loyalty, but find it to be difficult to apply in the military, especially in times of war. The principle of justices, which is the most common principle taken as an example when discussing principle loyalty, can be problematic for soldiers in times of war when justice of war is virtually impossible to define. In modern times war cannot be defined easily, and it is particularly difficult to draw the line between a state of war and a state of peace. Probably the most famous definition of war as "continuation of policy by other means" ${ }^{29}$ forged by the legendary von Clausewitz, is said to be outdated. The reformulated version of his definition has been lauded as ideal for the modern world "policy is the continuation of war by other means"30. Subversive activities, "soft power", "public diplomacy", and many other forms of interaction in international relations are all activities short of war, but can form a type of a perpetual state of war, particularly for those in the military. Hence, every action of those in the military, in any type of modern "conflict", is viewed through the prism of war, despite the fact that there is no mass armed conflict currently ongoing. It seems unreasonable to demand of a soldier to know what the just side is in war or this state of "latent war" in peace. All sides are convinced of their justness, and the unique state of war can provide utilitarian justification for pretty much every action under the veil of proportionality and collateral damage as soldiers face "the abyss of utilitarian apologetics for large-scale murder"31. In this situation, pretty much everything can be justified with "loyalty to principle" of justness and the lesser evil argument. As long as soldiers remain loyal to the highest interest of their nations, and apply violence only as means of achieving a lasting peace, we can argue that they remain loyal to the principle.

\section{When loyalties conflict}

Three levels of loyalty usually go hand in hand with each other. All legendary war stories about heroism and loyalty are cases in which individuals displayed loyalty on all three levels. But, is it possible for these loyalties to conflict? Is it possible that soldiers at times face the challenge of choosing one loyalty over another, and what should they do when such events unfold? Phenomenon of whistle-blowing represents precisely such a scenario - a scenario in which individuals find themselves facing an often times insolvable problem - whom should I remain loyal to - group, profession or nation? When actions of one's group members conflict with values of his profession and interests of his

28 Ibid. p. 43-44.

29 von Clausewitz, C. On War. Oxford: OUP, 2007, p.28.

30 This phrase is attributed to Michael Foucault.

31 Nagel, T. Mortal Questions. Cambridge: CUP, 1979, p. 56. 
nation, one must decide either to stay loyal to the group or to stay loyal to his profession and nation. In military context, the value of group loyalty is overwhelmingly emphasized at the expense of other loyalties as unit cohesion can mean the difference between success and failure. On the flip side, "the dynamics of loyalty and tight unit cohesion can contribute to war crimes and atrocities" ${ }^{\mathbf{3 2}}$ as it represents a powerful factor working against speaking out and blowing the whistle in favour of silence and cover-ups. When a military member does something that is in conflict with professional and institutional values and interests of his nation, it is he who is disloyal, both to his profession and nation. Why should then anyone be expected to remain loyal to a group member who is being disloyal to tradition and nation? It is our view that loyalty to profession and loyalty to nation are condicio sine que non of group loyalty, and that when some group members become disloyal to their profession and nation, there can be no justified group loyalty. Second and third level loyalties are prerequisites for first level loyalty. Moreover, a soldier's duty is to prevent behaviour that is detrimental to his profession or nation, and to report it; this is completely in accordance with loyalty because every military "needs people who blow the whistle if necessary... it needs, much more frequently so, soldiers who are willing to correct a colleague when they think him wrong, or even report him if necessary"33. Their militaries and their nations are the beneficiaries of them performing their duties. Remaining loyal to one's nation and tradition when they are conflicted with group loyalty is the only proper way to manage situations of loyalty conflict. We agree with authors who claim that "the whistle-blower is not being disloyal, but someone who is not led (astray) by loyalty" 34 but add that while not being led astray by group loyalty, the whistle-blower remains loyal to his profession and nation. Placing group loyalty above every other loyalty is a recipe for disaster. This represents failure of loyalty conflict management, and numerous historical examples "showed the working of group loyalty without loyalty to the larger values and institution and the consequences of such loyalties" 35 .

Can we expect of soldiers to recognize these levels of loyalty, and to properly manage loyalty conflicts? We firmly believe that every soldier intuitively knows what the right course of action is in such situations, and that excessive group loyalty is the thing standing between him and the right decision. Group loyalty is the greatest contributor to akrasia $^{36}$ or the lack of moral courage. Again, we go back to cadets from first pages of this paper. Despite a huge majority of them referring to their hypothetical colleague who blows the whistle as disloyal, things change once we eliminate the burden of group loyalty. The easiest way to do this is to place a member of some different military in the example. For example, no one ever said that actions of Sergeant Joe Darby in Iraq were cowardly or disloyal. On the contrary, his famous whistle-blowing on torture methods and obscene abuse of prisoners in Abu Ghraib are seen as heroic. He is perceived

\footnotetext{
32 French, S.E. The Code of the Warrior, p. 50.

33 Olsthoorn, P. Military Ethics and Virtues, p. 51.

34 Ibid. p. 69.

35 French, S.E. The Code of the Warrior, p. 51.

36 Akrasia (Greek $\alpha$ k $\rho \alpha \sigma i \alpha$ ) signifies weakness of will to act on moral judgment.
} 
as a "decent man", "honest soldier", etc. by those outside the US military. No matter how many examples such as this one we went through, cadets always recognized that group loyalty must not restrict other levels of loyalty. Often, they even reach the fair conclusion that immoral actions and cover-ups are detrimental to interests of the nation to which these individuals belong to. Even in the most extreme case of group disloyalty that we know of, the case of Dutch soldier Poncke Princen, who did the unthinkable and switched sides in the middle of conflict between colonial Netherlands and guerrillas in Indonesia, his actions are understood as manifestations of his loyalty to the principle of justice. So, if almost all of them know perfectly well that group loyalty cannot be used to justify immoral actions and disloyalty to profession and nation and if they see individuals who act on their professional and national loyalties against their group-members as moral and just, why is it so difficult for them to speak out against misbehaviour and crimes of their own comrades? Admittedly, there are multiple factors - from psychological to sociological, but if we use the favourite philosophical principle of novacula Occami ${ }^{37}$ on this complex issue, we will arrive to the other indispensable military virtue - courage, more specifically, lack of it.

\section{MORAL COURAGE}

To define courage is to solve a centuries long riddle. Courage was one of the central virtues in ancient Greek civilization, but even the wisest of philosophers found it hard to define. When faced with Socrates and his famous maieutic method, one of the Greek generals in Plato's dialogue on courage, Laches, offers many definitions of courage, but finally concludes - "for I fancy that I do know the nature of courage; but, somehow or other, she has slipped away from me, and I cannot get hold of her and tell her nature" $\mathbf{3 8}$. Aristotle famously defined courage in the same manner that he defined all virtues as midpoints between exaggerated extremes. In the case of courage, the middle point stands between excessive boldness or recklessness on one side of the spectrum and excessive fear or cowardice on the other. When searching for the appropriate definition of courage, we came across a brilliant book called The Mystery of Courage, in which its author collected more than a hundred attempts to define courage. He highlights that courage is "the most frequent theme in all world literature" ${ }^{39}$, that it has been one of the most important virtues in all known cultures, but in the end resorts to citing the words of Tim O'Brien, a Vietnam veteran, regarding the mystery of courage - "It is hard to be brave. It is hard to know what bravery is" $\mathbf{4 0}^{\mathbf{4 0}}$. It is a painstaking endeavour to try to define courage, so instead of pursuing such an effort, we shall rely on Sidgwick's minimal

37 The principle of Occam's Razor is the principle of choosing the simplest of all possible hypothesis.

38 Plato. On Socrates: Selected Writings. Lanham: Collectors Library, 2004, p. 121.

39 Miller, W.I. The Mystery of Courage. Cambridge: HUP, 2002, p. 8.

40 Ibid. 
explanation of courage, as "a disposition to face danger of any kind without shrinking"41. In military context, courage is more pivotal than in any other context, as it represents "the most central virtue to any discussion of military ethics" ${ }^{\mathbf{4 2}}$. Courage is a "martial virtue par excellence" $\mathbf{4 3}$ and entire military identities are built around it. To be courageous is the first prerequisite of being a soldier, just like being just is the first prerequisite of being a judge. Drawing a parallel between academics and soldiers, Maclntyre notes that "truthfulness is the indispensable professional virtue of all academic researchers, as courage is the indispensable professional virtue of soldiers" ${ }^{44}$. But if courage is so vitally important for the military, and if it represents the cornerstone of all military training, why do so few military members actually have the courage to express dissent when their fellow soldiers become disloyal to their nations? The answer partially lies in the type of courage the military emphasizes - physical courage. Physical courage means everything in the military and it is highly revered, not just in military circles, but by entire nations. But whistle-blowing requires an additional form of courage - moral courage. Moral courage is a phrase coined relatively late in English language, not before the nineteenth century, and it signifies the ability to "face the pains and danger of social disapproval in the performance of what someone believes to be duty" ${ }^{\prime 45}$. One requires moral courage to resist conformism and face group and public shaming, derision, embarrassment, and other consequences of whistle-blowing. In military environment, especially in critical times, these consequences can be perceived by soldiers as worse than severe physical pain or even death! As we mentioned, being courageous is probably the most important thing for a soldier, and from it follows that "to be branded a coward is amongst, if not, the worst insults that can be levelled at a warrior"46. Thus, it is no wonder that many soldiers think that being physically courageous is easier than being morally courageous, as it is "easier to be shot than to be laughed at and scorned"47. Throughout history, men have died in numbers to avoid shame and embarrassment and to prove their worthiness to the group, so we must not be surprised with the power and force of such fears. Surely, one must be extremely morally courageous to consciously face such consequences. It is precisely this type of courage, moral courage, that is necessary for proper loyalty conflict management. Only a brave person can remain loyal to his warrior traditions, his profession and his nation's interests even if it means putting his entire family on the edge of poverty, being ostracized, and called a coward by his own comrades.

Moral courage is different than physical courage but they do not necessarily exclude each other - on the contrary, moral courage often demands physical courage. There is no

41 Sidgwick, H. The Methods of Ethics, 7th ed. London: MacMillan and Co, 1907, p. 353.

42 French, S.E. The Code of the Warrior, p. 24.

43 Sparrow, R. Drones, Courage, and Military Culture. In G. Lucas (ed.). Routledge Handbook of Military Ethics. London: Routledge Taylor and Francis, 2015, p. 383.

44 MacIntyre, A.C. Military Ethics: A Discipline in Crisis". In G. Lucas (ed.). Routledge Handbook of Military Ethics. London: Routledge Taylor and Francis, 2015, p. 5.

45 Sidgwick, H. The Methods of Ethics, p. 345.

46 French, S.E. The Code of the Warrior, p. 24.

47 Miller, W.I. The Mystery of Courage. Cambridge: HUP, 2002, p. 254-255. 
organization in the world in which moral courage is so profoundly linked with physical courage than the military. Cases of whistle-blowers around the globe have shown that those who possess moral courage often times also require substantial physical courage to step forward. Much more than just losing their jobs is at stake here, even though loss of employment can jeopardize economic existence of entire families, especially when people get "dishonourably discharged" and when their former employers invest a lot of effort to make them "unemployable" for an extended period of time. Furthermore, military uses severe punishments for whistle-blowers, and they are "often penalized more heavily than would seem appropriate considering the harm they did"48. Who knows how many soldiers have died in the field when they expressed dissent and confronted their superiors or group members? Cases of world-famous military whistle-blowers like Bradley Manning and Joe Darby indicate that moral courage can come at the cost of serious physical peril, as both of their lives were in danger when they came forward. In the case of Darby, so much so that he "feared for his life for a while, and lived several years in protective custody at an undisclosed location'49. Not only are whistle-blowers not cowards, they epitomize warrior courage. We cannot but to recall the wise words of Thomas Fuller - "Many would be cowards if they had courage enough".

\section{CONCLUSION}

As we have demonstrated, it is not the lack of intellectual perception nor inability of deeper understanding that prevents soldiers from properly managing loyalty conflicts, rather it is the lack of moral courage. Therefore, some sort of a notion of moral courage must be incorporated in military training and education of all military members. We believe that more emphasis must be put on phronesis or prudentia ${ }^{\mathbf{5 0}}$ within virtue ethics in ethical education of officers, and that it would allow officers to recognize opportunities for excellence outside the realm of physical danger. Officers must be at an intellectual level of thinking that allows them to fully understand these concepts and to possess practical intelligence that enables them to exhibit courage "at the right time, to the right extent, and in the right cause"51. But this shift in approach to training and education is obviously easier said than done. Building group cohesion has been one of the focal points of military training throughout military history as is one of the most important factors of mission success. Unfortunately, it has been proved that there is an inverse relationship between cohesion and moral courage and that "the more socially cohesive a unit, the more prone to a lack of moral courage it is" $\mathbf{5 2}$. There is seemingly a certain

48 Olsthoorn, P. Military Ethics and Virtues, p. 67.

49 Ibid. p. 91.

50 The terms phronesis (Aristotle - $\varphi \rho o ́ v \eta \sigma \iota \varsigma$ ) and prudentia (St. Thomas Aquinas) refers to practical wisdom, prudence, necessary to recognize situations and contexts in which virtue can be displayed.

51 French, S.E. The Code of the Warrior, p. 237.

52 Olsthoorn, P. Military Ethics and Virtues, p. 52. 
paradoxical nuance to this - the more cohesion a group has the more physical courage can be expected from its members, but at the same time less moral courage. But the relationship between physical and moral courage is not a zero-sum game - physical courage can be displayed not only as not shrinking in the face of enemies, but also as not shrinking in the face of dangerous consequences of doing the right thing. The reality is that the nature of the military makes it difficult for moral courage to be appreciated, let alone for it to be placed at the same level as physical courage. Every military in the world has powerful mechanism for ensuring obedience and conformism, meaning that we must come to terms with the fact that militaries are in reality "no bastions of moral courage, and probably never will be" ${ }^{\prime 23}$. But that doesn't mean that things can't improve. We must insist that military education and training focus more on developing moral courage and proper understanding of loyalty, even at the cost of group cohesion. Perhaps such a demanding task should only be attempted in officers' education, as it seems unlikely that such approach would be optimal in military training of conscripts or even non-commissioned personnel. One thing that the military can definitely do is to provide better protection mechanism for those brave enough to speak up for what they believe, for those who remain loyal to their military's tradition and values and their national interests even at the cost of losing everything, including their life. One of the first steps in this challenging direction could be implementation of whistle-blowing case studies in ethical education of officers and cadets, in which the emphasis would be placed on the courage and loyalty displayed by their colleagues, and positive effects of their dissent on all of them. Gaining insight in personal dilemmas, decisions and motivation of those who spoke out could familiarize officers and cadets with whistle-blowers on a more personal level, and help them understand. To go one step further - can't there be a place, and a prominent one for that matter, for heroic whistle-blowers in military history textbooks?

Unfortunately, the military cannot do this alone. Regardless of how isolated from society every military is, it does not exist in a vacuum. In its efforts to raise the awareness about the possible positive effects of whistle-blowing, proper loyalty conflict management, and moral courage the military must be backed up by the entire society, especially policy-makers. There is no reason why military whistle-blowers, whose actions better their organizations and, indirectly, their entire nations, shouldn't be treated as heroes. Positive media coverage and NGO activities are simply not sufficient, albeit they can be very powerful. What is necessary is affirmative action from the top of the political ladder; political leaders must recognize that whistle-blowers in the military can at times contribute, not just to their organizations but also their societies, just as much as those brave soldiers who lay their lives down for their country. This may strike some as controversial or provocative, but if the end goal of any military is to preserve and establish a lasting peace for its nation then all those who contribute to this goal must be respected equally - whether they do it by killing for the sake of peace, willingly dying in this pursuit, or by bravely speaking out for the sake of peace when it is necessary.

53 Ibid. p. 53. 
This article was written as a part of the scientific project of the Military Academy of the Defense University, "Military in the political system of Serbia", financed by the MoD of RS (project no. VA-DH/1/19-21).

Author: Dragan Stanar, PhD, born 1986. He is a Doctor of Philosophy (Military Ethics). Associate Professor at the Faculty of International Politics and Security of the Union Nikola Tesla University in Belgrade and an Adjunct Professor at the Military Academy in Belgrade, where he teaches Military ethics. Teaches Military ethics and moral at the National Defense School of the University of Defense in Belgrade. Member of the Board of Directors of the European Society for Military Ethics (EurolSME). Editor-in-chief of the online Ethics of Peace and War collection on Project Rastko. Fields of research: military ethics, ethics of war, philosophy of violence.

How to cite:STANAR Dragan. Martial Virtues and Whistle-Blowing: Loyalty Misplaced and Courage Misunderstood. 2021, 30 (2), 026-038. ISSN 1210-3292 (print), 2336-2995 (online). Available at: www.vojenskerozhledy.cz 


\title{
Applicability of Artificial Intelligence in Decision-Making for Land Forces
}

\author{
Použitelnost umělé inteligence v \\ rozhodovacím procesu pozemních sil
}

\section{Paul Tudorache}

Abstract: Similar to other fields, also in the military one, the Artificial Intelligence has become recently an evident solution for optimizing specific processes and activities. Therefore, this research paper aims to highlight the potential uses of Artificial Intelligence in the military operations carried out by the Land Forces. In this regard, analysing the framework of the operations process and applying suitable research methodology, the main findings are related to Al's contributions in optimizing commander's decisions during the progress of planning and execution. On the other hand, picturing the Al upgrated combat power of the Land Forces is another significant result of this study.

Abstrakt: $\quad$ Podobně jako $v$ jiných oblastech, také ve vojenské oblasti se umělá inteligence stala $v$ poslední době evidentním řešením pro optimalizaci konkrétních procesů a činností. Cílem tohoto príspěvku je upozornit na možnosti potenciálního využití umělé inteligence ve vojenských operacích prováděných pozemními silami. Hlavní zjištění založená na analýze rámce procesu operace s využitím vhodné metodologie výzkumu se týkají vlivu umělé inteligence na optimalizaci rozhodnutí velitele během procesu plánování a vedení operací. Dalším významným výsledkem této studie je představení umělé inteligence jako nástroje zvyšující bojovou sílu pozemních sil.

Key words: $\quad$ Al; Operations Process; MDMP; Adjustment Decisions; Combat Power.

Klíčová slova: UI; proces operace; vojenský rozhodovací proces; aktualizace rozhodování; bojová síla. 


\section{INTRODUCTION}

The interest of the world countries to develop Artificial Intelligence (Al), with wide applicability in various fields, has grown lately, becoming at this time a real competition between state actors. Specific to the military field, different armies, trying to gain operational advantages over their opponents, make huge efforts to revolutionize their military capabilities by developing and integrating $\mathrm{Al}$ into suitable activities and processes. By far, the most advanced armies in the field of Al development are those belonging to the United States of America (USA), Russian Federation and China, whose strategies cover all physical areas of the operational environment (OE), including space, and information environment with its component of cyberspace.

To emphasize the need of using $\mathrm{Al}$ in the military field, various researches have been conducted, which have concluded that Al has a multiple applicability, ranging from decision-making, intelligence, surveillance, reconnaissance (ISR) and all its derivatives, cyber defence, information operations (IO), up to anti-access/area-denial (A2/AD), and so on. In this sense, one of the most interesting surveys is RAND Project Air Force (PAF), completed in 2018, and whose primary scope consisted in identifying the most important Al's military applications in the USA, Russian Federation and China ${ }^{1}$ (figure 1).

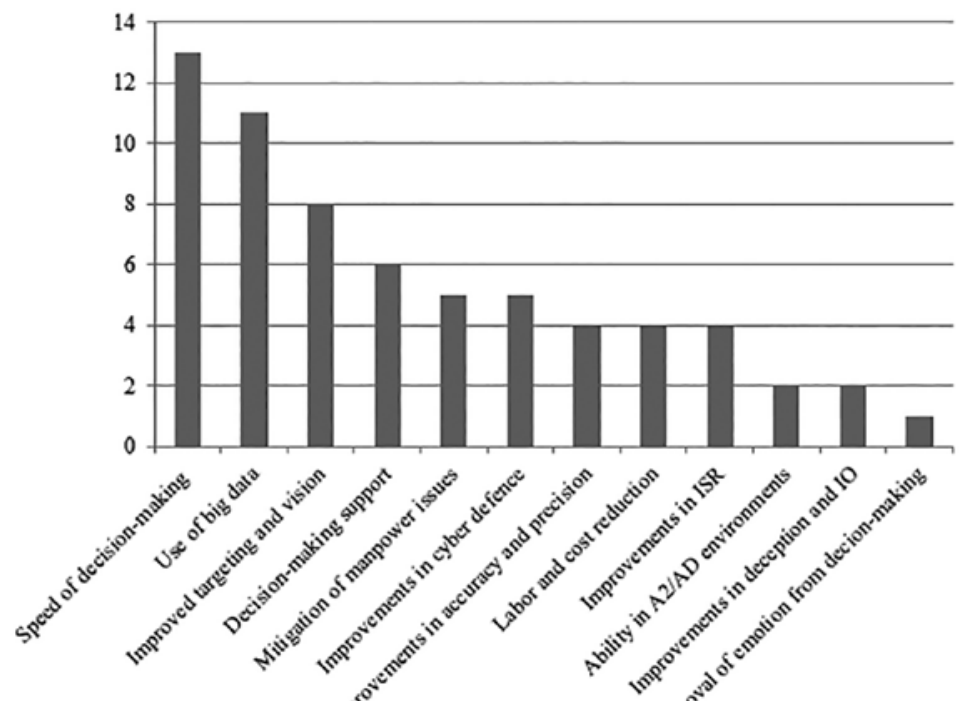

Figure 1: Applicability of Al in the military field

1 MORGAN, Forrest, BOUDREAUX, Benjamin, LOHN, Andrew, ASHBY, Mark, CURRIDEN, Christian, KLIMA, Kelly and GROSSMAN, Derek. Military Applications of Artificial Intelligence: Ethical Concerns in an Uncertain World. Santa Monica, California: RAND Corporation, 2020, pp. 5-6. ISBN 978-1-9774-0492-3. [cit. 2020-12-20]. Available from: bit.ly/2KMtOII. 
Source: MORGAN, Forrest, BOUDREAUX, Benjamin, LOHN, Andrew, ASHBY, Mark, CURRIDEN, Christian, KLIMA, Kelly and GROSSMAN, Derek . Military Applications of Artificial Intelligence: Ethical Concerns in an Uncertain World. RAND Corporation. 2020, p. 16. ISBN 978-1-9774-0492-3. Available from: bit.ly/2KMtOll

Another important perspective to consider is the one adopted by North Atlantic Treaty Organization (NATO), according to which, Al development becomes a priority for the next 20 years, imprinting the following areas: decision-making, command, control, communications, and computers (C4) correlated with the ISR field (C4ISR), weapons and effects, platform autonomy, planning capabilities, chemical, biological, radiological and nuclear (CBRN), medical, enterprise management, logistics, cyber and info-space, training ${ }^{2}$. In the same report, it is stated that NATO's opponents will try to develop Al for revolutionizing cyber, information, aberrant behaviour, and improvised explosive device (IED) capabilities ${ }^{3}$. A broader approach to NATO's trends in Al developments (time horizon 2035) is pictured in table 1.

Table 1: NATO's perspectives in Al development - time horizon 2035

\begin{tabular}{|c|c|c|c|c|}
\hline \multirow{4}{*}{ 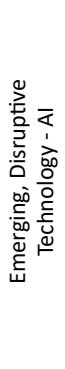 } & $\begin{array}{l}\text { Technology } \\
\text { Focus Areas }\end{array}$ & Estimated Impact & Technology Readiness Levels (TRL) & $\begin{array}{l}\text { Estima- } \\
\text { ted Time } \\
\text { Horizon }\end{array}$ \\
\hline & $\begin{array}{l}\text { Advanced } \\
\text { Algorithms }\end{array}$ & \multirow[b]{2}{*}{ Revolutionary } & $\begin{array}{l}\text { TRL } 4 \text { - component and/or breadboard } \\
\text { validation in a specific laboratory }\end{array}$ & \multirow{2}{*}{2030} \\
\hline & Applied AI & & $\begin{array}{l}\text { TRL } 6 \text { - system/ subsystem/ } \\
\text { prototype demonstration in } \\
\text { a specific environment }\end{array}$ & \\
\hline & $\begin{array}{l}\text { Human-Machi- } \\
\text { ne Symbiosis }\end{array}$ & High & $\begin{array}{l}\text { TRL } 4 \text { - component and/or breadboard } \\
\text { validation in a specific laboratory }\end{array}$ & 2035 \\
\hline
\end{tabular}

Source: STO. Science \& Technology Trends 2020-2040: Exploring the S\&T Edge. Brussels: NATO Science \& Technology Organization. 2020, p. 15. Available from: bit.ly/3rWz1rx

All these developments will be integrated in the principle of "intelligent, interconnected, distributed and digital (I2D2)"4, impacting the military capabilities, and especially those used in decision-making.

As can be seen from the begining, one of the most important Al applicability in the military filed is to optimize decision-making processes, with positive impacts on its effectiveness and efficiency.

2 STO. Science \& Technology Trends 2020-2040: Exploring the S\&T Edge. Brussels: NATO Science \& Technology Organization, 2020, pp. 55-56. [cit. 2020-12-20]. Available from: bit.ly/3rWz1rx.

3 Ibid. p. 56.

4 Ibid. p. 7. 


\section{RESEARCH METHODOLOGY}

Taking into consideration these preliminary theoretical aspects, the purpose of this study is to determine some potential uses of Al for optimizing decision-making in the field of Land Forces' operations. The objectives, derived from the purpose of the study, are limited to: identifying the Al possibilities for optimizing the operations process; visualising Al contributions to the optimization of decision-making.

To cover these objectives are defined two research hypotheses: Al's capabilities influence in a positive fashion the Land Forces' operations process; during Land Forces' operations, the decisions of tactical commanders largely depend on the development and integration of Al's capabilities into suitable planning and execution activities.

Consequently, this study is conducted using the following research methodology:

- Reviewing the relevant literature - substantiates from theoretical stand point the proposed scientific approach;

- Empirical research based on observation - aims to exploit the elements resulting from the personal experience in the field of military operations accumulated as a result of multinational missions, exercises and training initiatives, in which I took part;

- Strengths, weaknesses, opportunities and threats (SWOT) analysis on the use of AI in the Land Forces' operations-aims to identify the positive and negative aspects so as to support the validation of the formulated hypotheses.

\section{LITERATURE REVIEW}

In connection with this research, there is an abundance of relevant studies conducted in the field of optimizing military operations using Al technology. Although most studies have valuable results, the most relevant are:

- "Artificial Intelligence and Operational-Level Planning: An Emergent Convergence" - analyzes the benefits of upgrading the division-level planning methodology using suitable Al tools; although the study concluded that Al can support significant aspects of division-level military decision making process (MDMP), also would be necessary to analyze the potential benefits of Al for combat functions ${ }^{5}$;

- "Artificial Intelligence and the Future of the Operational Art" - evaluates the possibilities in which Al may facilitate the operations process; performing two case studies, the most relevant results are related to the enhancement of operational art and mission command, using Al tool as a force multiplier ${ }^{6}$;

5 BRANCH, William. Artificial Intelligence and Operational-Level Planning: An Emergent Convergence. Kansas: Fort Leavenworth, 2018, pp. 47-48. [cit. 2021-05-19]. Available from: bit.ly/2S4DYB5.

6

OLIVA, Lazaro. Artificial Intelligence and the Future of Operational Art. Kansas: Fort Leavenworth, 2018, p. 36. [cit. 2021-05-18]. Available from: bit.ly/3yfnAOJ. 
- "A Tactical and Strategic Al Interface for Real-Time Strategy Games" - introduces Al interfaces into Soar and Simulation Based Tactics Mining (SBTM) tactical systems to help commanders and staff in exercising command and control (C2) tasks ${ }^{7}$;

- "Artificial Intelligence for Decision Support in Command and Control Systems" approaches the use of Al for decision-making in intelligence and operation processes, based on observe, orient, decide, and act (OODA) loop; most important findings are located at $\mathrm{C} 2$ level during the activities of sense-making, planning and execution. $^{8}$

\section{OPERATIONALIZATION OF CONCEPTS}

In carrying out this study, it will be used the following concepts: Al, operations process, planning, execution, MDMP, execution decisions, adjustment decisions, and combat power. In this research, the concepts will be used with the following meanings:

- Al - "the ability of machines to perform tasks that normally require human intelligence - for example, recognizing patterns, learning from experience, drawing conclusions, making predictions, or taking action - whether digitally or as the smart software behind autonomous physical systems" ${ }^{\prime \prime}$; during this study, Al will be used as an independent variable which will be transposed at the level of each subsequent concept (dependent variable);

- Operations process - "the major command and control activities performed during operations: planning, preparing, executing, and continuously assessing the opera-

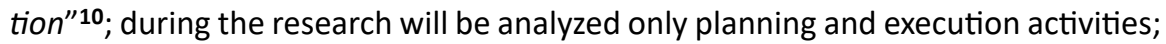

- Planning - "the art and science of understanding a situation, envisioning a desired future, and determining ways to bring that future about"11; it is the primary activity that starts the operations process;

- Execution - "the act of putting a plan into action by applying combat power to accomplish the mission and adjusting operations based on changes in the situati$o{ }^{\prime \prime}{ }^{12}$; in other words, it can be resumed at putting into practice the generated plan respecting the commander's intent;

7 VAN LENT, Michael, CARPENTER, Paul, MCALINDEN, Ryan, TAN GUAN, Poeny. A tactical and Strategic AI Interface for Real-Time Strategy Games. California: University of Southern California, 2004. [cit. 2021-05-19]. Available from: bit.ly/3v0kgFa.

8 SCHUBERT, Johan, BRYNIELSSON, Joel, NILSSON, Mattias, SVENMARCK, Peter. Artificial Intelligence for Decision Support in Command and Control Systems. Florida: ICCRTS, 2018. [cit. 2021-05-19]. Available from: bit.ly/2QBzv8A.

9 USAF. The United States Air Force Artificial Intelligence Annex to the Department of Defence Artificial Intelligence Strategy [online]. 12.09.2019 [cit. 2020-12-22]. Available from: bit.ly/37HhPOB.

10 ADP 5-0. The Operations Process. Washington, DC: Headquarters, Department of the Army, 2019, p. 1-4. PIN: 102805-000. [cit. 2020-12-22]. Available from: bit.ly/3u6R26Q.

11 Ibid. p. 2-1.

12 Ibid. p. 4-1. 
- MDMP - "an iterative planning methodology to understand the situation and mission, develop a course of action, and produce an operation plan or order"13; it is the planning methodology used by tactical structures with organic staff, based on detailed planning;

- Execution decisions - "implement a planned action under circumstances anticipated in the order"14; practically, these decisions are equivalent with decisions points (DPs) identified during the wargaming phase;

- Adjustment decisions - "the selection of a course of action that modifies the order to respond to unanticipated opportunities or threats"15; in other words, they represent those DPs that commander did not meet in the wargaming the courses of actions (COA);

- Combat power - "the total means of destructive, constructive, and information capabilities that a military unit or formation can apply at a given time"16; it is shaped by the interdependence of the following elements "leadership, information. command and control, movement and maneuver, intelligence, fires, sustainment, and protection"17; besides leadership and information, the other elements represent combat or warfighting functions.

The logic algorithm of the study is based on correlating the analyses that will be carried out for all dependent variables. This will be useful for accomplishing the purpose and objectives designed in the preamble of this research (figure 2).

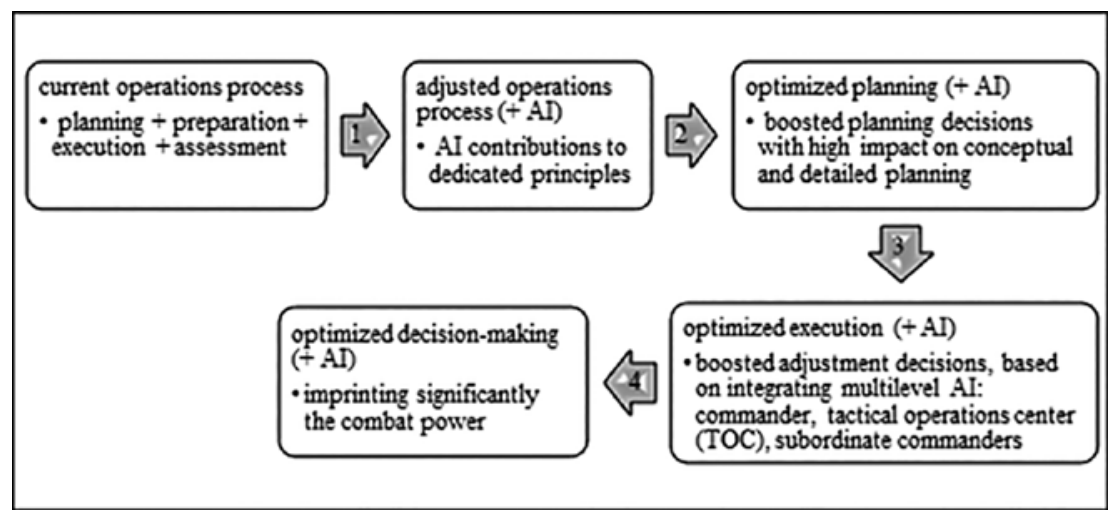

Figure 2: The logic algorithm of optimizing decision-making using Al capabilities

\footnotetext{
13 Ibid. p. 2-17.

14 WADE, Norman. BSS5 Smart Book: The Battle Staff - Leading, Planning \& Conducting Military Operations. Florida: The Lightning Press, 2015, p. 1-56. ISBN: 978-1-935886-63-1.

15 lbid.

16 ADP 3-90. Offense and Defence. Washington, DC: Headquarters, Department of the Army, 2019, p. 1-4. PIN: 102987-000. [cit. 2021-04-28]. Available from: bit.ly/32YfWtv.

17 lbid.
} 
Therefore, solving this research topic can be limited to approaching each piece of the puzzle above, having as an initial point the adjustment of the current operations process from Al perspective.

\section{ADJUSTING THE OPERATIONS PROCESS USING AI CAPABILITIES}

From the personal researches conducted so far in the field of Land Forces, the general framework of Al applicability is the operations process. Also in starting the validation of the research hypotheses it will be used the results of SWOT analysis from table 2 .

Table 2: SWOT analysis on using Al in the Land Forces' operations

\begin{tabular}{|l|l|}
\hline Strengths & Weaknesses \\
$\begin{array}{l}\text { - amplifying the combat power of organic elements; } \\
\text { - optimizing the activities and their dedica- } \\
\text { ted principles of the operations process; } \\
\text { - improving the fulfilment of the dedicated } \\
\text { personnel's responsibilities and tasks; } \\
\text { - making coherent and timely decisions }\end{array}$ & $\begin{array}{l}\text { - manifesting the limitations on its use, especially } \\
\text { from the perspective of expressing emotions; } \\
\text { - huge efforts in developing and integra- } \\
\text { ting it into the military operations }\end{array}$ \\
\hline $\begin{array}{l}\text { Opportunities } \\
\begin{array}{l}\text { - boosting it by correlating with other } \\
\text { types of new military technologies; } \\
\text { - replacing the combatant perso- } \\
\text { nnel with dedicated Al elements; } \\
\text { - supplementing the mental agility of commanders and } \\
\text { subordinate personnel during operations conducted in } \\
\text { volatile, uncertain, complex and ambiguous (VUCA) OEs }\end{array}\end{array}$ & $\begin{array}{l}\text { Threats } \\
\text { - making decisions instead of commanders and } \\
\text { by organic staff and during different situations }\end{array}$ \\
\hline
\end{tabular}

Considering the results of SWOT analysis (strengths), definitions given above and the principles dedicated to the operations process such as driving the operations process, building/maintaining situational understanding, and applying critical and creative thinking ${ }^{18}$, in table 3 are highlighted some of the possible Al contributions in supporting Land Forces' commanders and staffs during the progress of military operations.

18 ADP 5-0. The Operations Process. Washington, DC: Headquarters, Department of the Army, 2019, p. 1-7. PIN: 102805-000. [cit. 2020-12-22]. Available from: bit.ly/3u6R26Q. 
Table 3: Al contributions during the operations process

\begin{tabular}{|l|l|}
\hline $\begin{array}{l}\text { Principles of } \\
\text { operations process }\end{array}$ & Al contributions \\
\hline $\begin{array}{l}\text { Driving the ope- } \\
\text { rations process }\end{array}$ & $\begin{array}{l}\text { Supporting commander and dedicated headquarter (HQ) in: understanding the OE/ } \\
\text { Area of Operation (AO); visualising the desired end state; describing the com- } \\
\text { mander's visualisation; directing combat functions and subordinate forces. }\end{array}$ \\
\hline $\begin{array}{l}\text { Building/maintai- } \\
\text { ning situational } \\
\text { understanding }\end{array}$ & $\begin{array}{l}\text { Enhancing/updating/optimizing: operational/mission variables; intelligence process; running } \\
\text { estimates; collaboration and liaisons between structures and other partnered forces. }\end{array}$ \\
\hline $\begin{array}{l}\text { Applying critical/ } \\
\text { creative thinking }\end{array}$ & $\begin{array}{l}\text { Supporting the commander and dedicated HQ in: making judgments by extracting and correla- } \\
\text { ting the intelligence products provided; finding solutions for approaching unfamiliar situations. }\end{array}$ \\
\hline
\end{tabular}

To avoid misunderstandings, Al capabilities will not replace the commander during the progress of the operations process, but will support him through counseling activities, so as to maximize the probability of performing the actions triggered by his decisions. On the other hand, within this whole spectrum of activities, the essence of using Al will be materialized in the quality of commander for driving the operations process, and for this reason the most targeted element for optimization will be the commander's intent. In the same manner, related to the staff - Al relationship, the last one will support its organic elements (S2, S3, and so on) to assist commander throughout the operations process. The most targeted elements of Al optimization will be:

- understanding the situation - involves the enhancement of creating the common operational picture (COP);

- implementing commander's decisions and exercising the control over the operation - through optimizing the TOC activity;

- assessing the progress of the operation - involves the improvement of measures of performance (MOP) and measures of effectiveness (MOE).

Also, all these findings can be supported by similar results according to which, possessing this technology, "the commander and his staff can leverage Al to facilitate the operations process. Al will serve as a force multiplier through the planning, preparation, and execution" 19 .

Consequently, having all these Al contributions to the operations process, it can be stated that the first research hypothesis is validated. In this manner, the operations process will be much more robust, whose application will ensure the operational flexibility necessary to generate the desired lethal/nonlethal effects, and implicitly the desired end state.

19 OLIVA, Lazaro. Artificial Intelligence and the Future of Operational Art. Kansas: Fort Leavenworth, 2018, p. 35. [cit. 2021-05-18]. Available from: bit.ly/3yfnAOJ. 


\section{AI CONTRIBUTIONS TO DECISION-MAKING}

Although Al is beneficial to all activities describing the operations process, the fallow up analysis will be directed at the level of planning and execution, due to the fact that the effects of using Al are much more visible on these activities. Practically, I will analyze the aspects of decision-making in planning and execution, from the perspective of integrating specific Al capabilities.

\subsection{Optimizing decision-making during tactical planning}

Even though most decisions are made during execution, they are also the subject of operation's planning. At tactical level, for military structures with organic staff, the context of decision-making is shaped by the MDMP, used by the majority of Land Forces from NATO, as detailed planning. Addressing previously the issue of adapting the MDMP by integrating Al capabilities, the conclusions drawn in the study conducted under Romanian Ministry of National Defence (MoND), which I led it as a project manager ${ }^{\mathbf{2 0}}$, can be summed up in that $\mathrm{Al}$ is suitable for all dedicated steps including 20 tasks, as follows ${ }^{\mathbf{2 1}}$ :

- Step I/Receipt of mission - 3 tasks: running estimate, initial situation's assessment, and initial commander's guidance;

- Step II/Mission analysis - 7 tasks: initial intelligence preparation of the battlefield (IPB), identifying critical facts and developing assumptions, initial risk management (RM), initial development of commander's critical information requirements (CCIR), initial commander's intent, initial mission statement, and initial planning guidance; from all these tasks, special attention should be paid to IPB, as well as to mission statement and commander's intent, the last two coagulating in the foundation of developing friendly forces COAs;

- Step III/COA development - 4 tasks: assessment of the relative combat power, arraying forces, generating the tactical options, and developing a broad concept; for the task of generating options, Al will not only improve the COAs generated by S3, but also it will multiply the tactical options in accordance with mission statement and commander's intent;

- Step IV/COA analysis - 1 task: wargaming the operation and assessing the results.

20 Study no 24/609-5360. Studiu privind realizarea unui model al MDMP-ului adaptat la cerințele mediilor VUCA și JIIM, integrând aspectele socio-culturale și inteligența artificială (Study on Developing a Model for Adapting the MDMP to the VUCA and JIIM Requirements, Integrating SocioCultural Aspects and Artificial Intelligence. [cit. 2021-05-18]. Available from: bit.ly/3yhUXAx.

21 TUDORACHE, Paul. Adaptarea structurilor militare din Forțele Terestre la cerințele acțiunii în medii VUCA și JIIM (Adapting military structures from Land Forces to the requirements of VUCA and JIIM environments). Sibiu: "Nicolae Bălcescu" Land Forces Academy Publishing House, 2020, pp. 89-91. ISBN: 978-973-153-376-6. 
- Step V/COA comparison -2 tasks: performing the analysis of advantages, disadvantages, and comparing COAs;

- Step $\mathrm{VI} / \mathrm{COA}$ approval - 2 tasks: commander's decision, and developing final planning guidance;

- Step VII/Orders production, dissemination and transition - 1 task: planning's transition to preparation/execution.

- Although the commander influences all MDMP tasks through his conceptual planning, it can be seen that the decisions with the greatest impact on planning are related to IPB and approval of friendly forces' COA. For the IPB situation, Al will be able to advice the commander so that he is aware of all relevant aspects characteristic to the enemy when adopting his probable COAs. In this regard, there have been already developed Al tools for IPB optimization, one of them consisting in Mission Assistance Computing (MAC) whose application "generate the IPB outputs most heavily utilized throughout MDMP, the event template, initial information requirements, decision support matrix, and decision support template"22.

Instead, for the second situation, Al will be able not only to propose the commander that COA with the highest probability of success, but also to make him aware of the necessity for integrating within selected COA the probable actions of other interest audiences such as indigenous population, local authorities, and other parties that may influence the operation.

\subsection{Optimizing decision-making during tactical execution}

Certainly, the execution will be the most advantaged in case of using Al capabilities. Al will influence in a positive fashion commanders' decisions and implicitly the HQ's activity, and subordinate forces' actions. The context of integrating $\mathrm{Al}$ in the execution is shown in figure 3 , where the key element in attaining the end state is the adjustment decisions.

22 BRANCH, William. Artificial Intelligence and Operational-Level Planning: An Emergent Convergence. Kansas: Fort Leavenworth, 2018, p. 40. [cit. 2021-05-19]. Available from: bit.ly/2S4DYB5. 


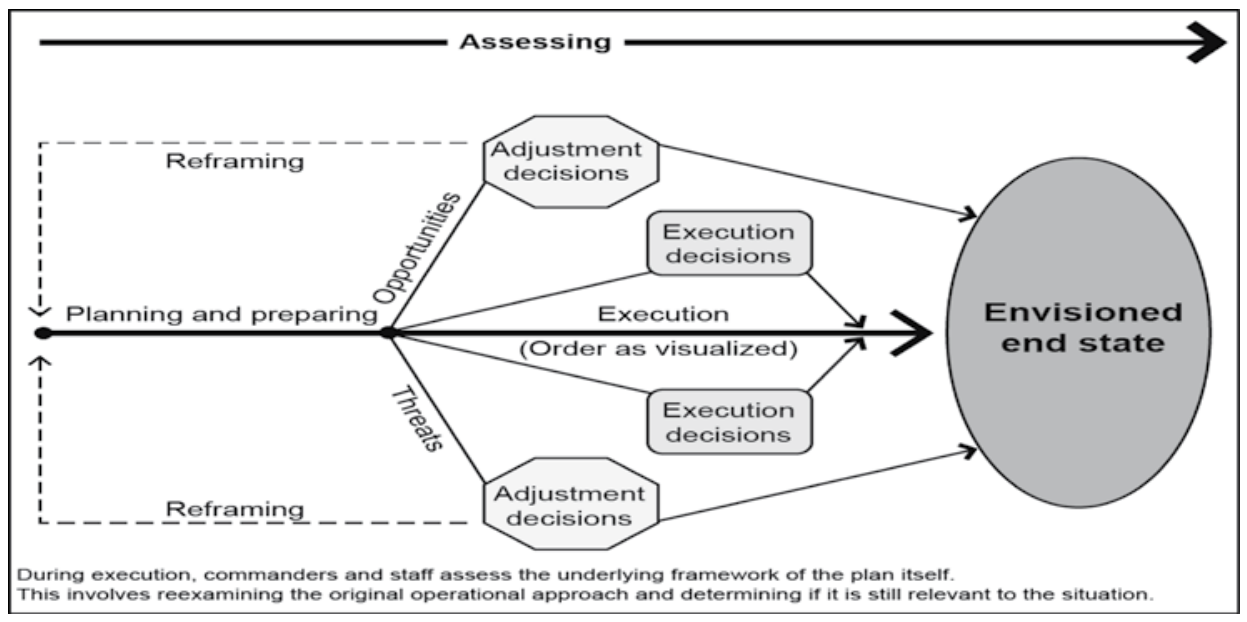

Figure 3: Decision-making during execution

Source: ADP 5-0. The Operations Process. Washington, DC: Headquarters, Department of the Army. 2019, p. 4-6. PIN: 102805-000. Available from: bit.ly/3u6R26Q

As I stated in the operationalization of concepts, execution decisions trigger actions in accordance with facts anticipated during planning phase, different from adjustment ones that are implemented to adapt or modify the COA approved. It becomes easily to understand that the biggest problems during performing execution are caused by the last of these. In this context, the use of Al will increase commander's mental agility, on the one hand, and on the other hand, it will supplement the decisional expertise and the level of his emotional intelligence (EI). Other secondary effects of optimizing adjustment decisions based on Al can be linked with the decisional speed and accuracy, which are important requirements to the operational flexibility.

Also, this principle can be applied at the level of subordinate commanders if Al applications are available (for counselling purposes). In this case, Al must be integrated in the command posts (CP) architecture. For instance, in a tactical operational context, assuming a battalion (BN) in charge with execution, besides the BN commander (CDR) who is responsible for adjusting the execution in accordance with unanticipated threats and opportunities, Al will be also beneficial for company (COY) and platoon (PLT) commanders to support them in applying the adjustment decisions made by BN commander. Moreover, taking into consideration the VUCA characteristics of the current and future $\mathrm{OE}$, each commander at any level will be the subject of making decisions in unknown circumstances, meaning the ability to adopt the adjustment decisions. More schematically, the underlined aspects for tactical operational context are highlighted in figure 4. Even if, the figure is designed for BN level, the principles may be appropriate for the brigade (BDE) and division (DIV) levels, in this case being necessary to change the operational context with two levels up. 


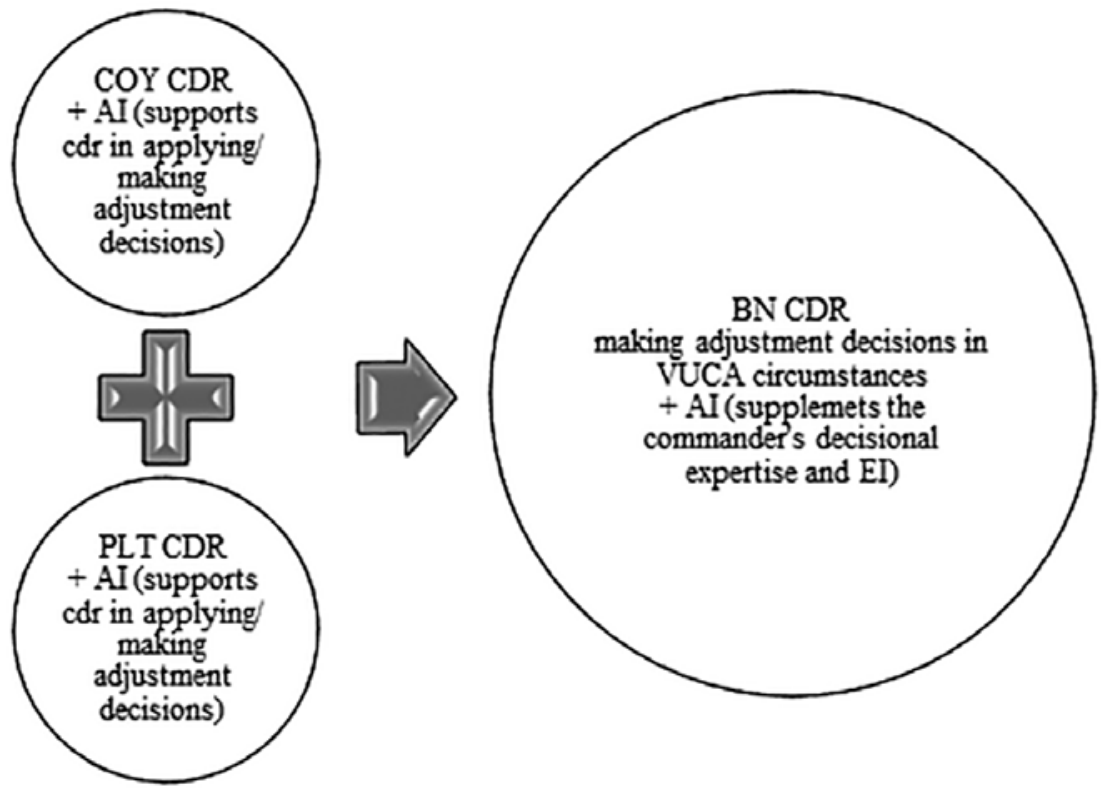

Figure 4: Al Perspectives in optimizing BN decision-making

NOTE: to ensure the efficient application of BN CDR's adjustment decisions (Al supported), it would be also necessary to develop Al's tools suitable for COY and PLT CDRs, who in turn make adjustment decisions.

Also, to have the adjustment decisions implemented, some $\mathrm{Al}$ insertions are required at the staff level, especially in optimizing the TOC activity. In general, during execution the TOC is responsible for putting into practice the commander's decisions. From this perspective, integrating Al in the TOC architecture, improvements will be made on: monitoring the designated $\mathrm{AO}$, updating the $\mathrm{COP}$, exercising the $\mathrm{C} 2$ over maneuvering forces during the progress of their missions, ensuring a prompt reaction to critical events, counseling the commander/staff, and coordinating fighting capabilities from organic or provided by higher echelon. In this way, the TOC's battle line, especially the battle captain (BC) and battle non-commissioned officer (NCO) will have amplified fighting abilities. Also to support the second research hypothesis' validation, a significant example of one of the first Al tool for optimizing decision-making is Real-time Adversarial Intelligence and Decision-making (RAID) developed by US Army based on Deep Green (DG) technology. Essentially, RAID "leverages novel approximate game-theoretic and deception-sensitive 
algorithms to provide real-time enemy estimates to a tactical commander" 23 during the progress of the execution.

The last, but not least, all these multilevel insertions of Al for optimizing decision-making will be also transposed at the level of combat power applied during the execution. Understood as the correlation between all destructive, constructive and information capabilities, the combat power will have some elements upgraded with Al capabilities. As highlighted in figure 5 , even if it would be indicated to have all combat functions amplified, for optimizing decision-making it is required to have $\mathrm{Al}$ insertions at least for components of leadership, information, C2, and manoeuvre.

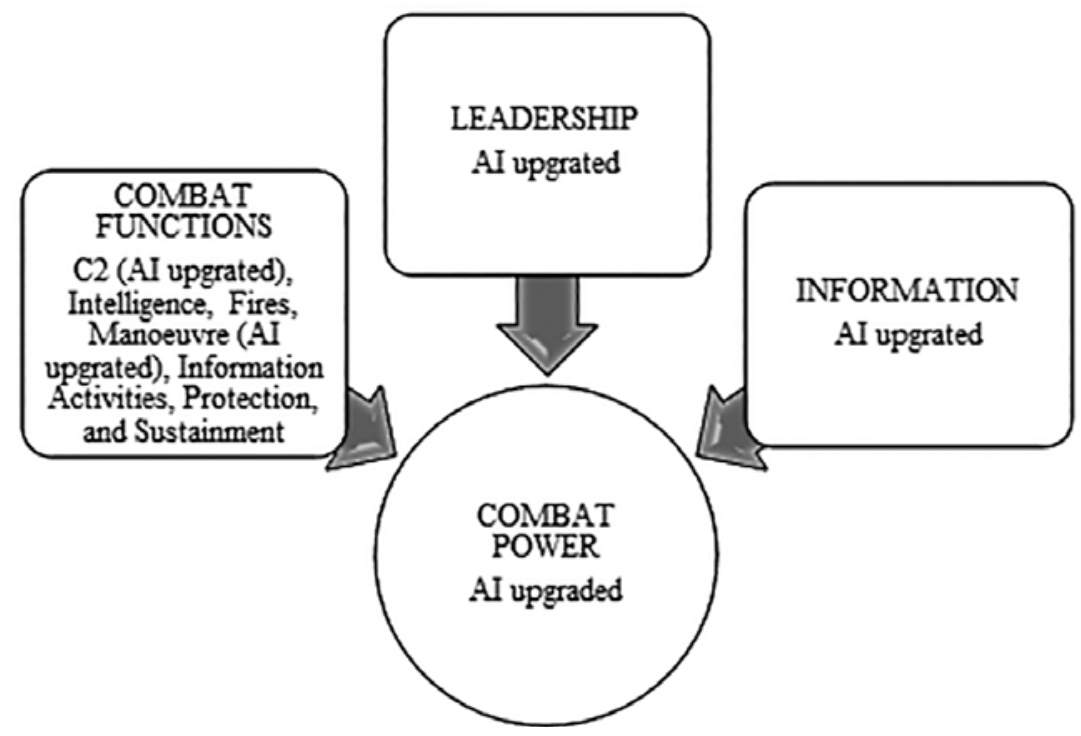

Figure 5: The combat power during execution - Al upgraded

NOTE: to optimize the application of combat power during the battlefield (directed at the right time and the right place), it is desired to have some specific elements reinforced with Al capabilities.

Also, for clarification, the information from figure above is different from the combat functions of intelligence and information activities. It refers to the overall cooperation between internal and external structures/sections based on the flow of information which can be horizontal and vertical (upward/downward) in nature.

In this formula with Al included, the commander will be able more easily to direct the combat power during the progress of execution.

23 KOTT, Alexander, OWNBY, Michael. Tools for Real-Time Anticipation of Enemy Actions in Tactical Ground Operations. Virginia: Command and Control Research Program, 2005, p. 170. [cit. 2021-05-19]. Available from: bit.ly/3yi64cJ. 


\section{CONCLUSION}

At the end of this research paper, it can be appreciated that the issues addressed, covering all research objectives through validating the formulated research hypoteses, have provided an innovative strategy to optimize decision-making for Land Forces' commanders, based on integrating Al capabilities. Even if the context of the analyses was limited to the tactical military structures, the highlighted principles can be also applied to higher levels of the Land Forces' operations such as operational and strategic, whose commanders also encounter difficult decisional contexts.

On the other hand, the innovative method of integrating Al at the tactical decision-making, is extremely suitable because, as we have seen, the current OEs, and especially those foreseen in the future, with pronounced VUCA characteristics, request different level commanders to posses mental agility in order to make bold and sound decisions. In these high changeable contexts, Al will significantly supply commanders with decision-making skills and will support their El in high intensity situations.

As far as the planning decisions are concerned, the benefits of using Al can be manifested in the form of counselling commander and S2 personnel during IPB decisions, imprinting the enemy COAs which will be more probable, meaning much closer to the reality. Furthermore, anticipating the enemy with high accuracy (improved probability), the S3 section will be much more able to develop feasible COAs for friendly forces, shaping the commander's framework to adopt the best decision in COA's approval.

Also, as we have seen, the most difficult decisional situations during execution are outlined in the context of making adjustment decisions, which are required to counter different threats or to exploit opportunities. In these circumstances, possessing multilevel Al capabilities, integrated coherently in the architecture of decision-making process, different level commanders will be capable to direct and apply the organic combat power in a way which will overwhelm the enemy.

All in all, the proposed strategy for boosting Land Forces' decision-makers needs to have $\mathrm{Al}$ integrated and validated for all variables and stages of the decisional process such as:

- Commander - is the primary variable in the process, being responsible for overcoming the DPs during the progress of the operation; the most powerful Al tool should be developed at this stage to reinforce his mental agility;

- Dedicated HQ - is another variable that must be the subject of Al integration and validation; at this stage, Al will be the actual catalyst for staff sections in their work to support the commander with area expertise, before making decisions; also, Al optimizations will work for enabling the conversion of commander's decisions into desired actions, based on optimizing the staff activity; in this case HQ is the bridgehead which links the commander and subordinate units/subunits;

- Subordinate units/subunits - are the actionable variables/agents responsible for creating the effects on the battlefield (OE/AO); at this lower stage, Al will boost the effort of subordinate commanders to accomplish specific missions and tasks, having in their mind the superior commander's intent as well as his adjustment decisions; moreover, during the execution, subordinate commanders may deal with 
unknown situations, and being Al orchestrated, they will be able to assume and make proper decisions to deconflict the subject areas.

Based on these principles, the logic algorithm presented during this research has pointed the most important elements of decision-making process that must be optimized. Also another strategy to boost decision-making using Al consists in selecting individual elements in accordance with the prioritization criteria and resources available for Land Forces. But to have all Al benefits, the strategy should be applied using a step-by-step algorithm, which starts with planning. After validation, the algorithm will continue in the same manner with execution, and will end with integration of Al capabilities, validated for both stages. It is recommended that the final validation of Al products to be conducted using computer assisted exercise (CAX) supported by command post exercise (CPX). Both will be constructive, virtual and real in nature, respecting the typology of simulations in the military field.

Consequently, as other revolutionary applications of Al technology in the military field such as fire precision and lethality, information accuracy, force resilience and so forth, the optimization of decision-making is another prerequisite for the success of future Land Forces' operations in terms of attaining the effectiveness and efficiency in high intensity VUCA environments.

\section{LIST OF ABBREVIATIONS}

\begin{tabular}{|c|c|}
\hline$A 2 / A D$ & Anti-access/Area-denial \\
\hline Al & Artificial Intelligence \\
\hline $\mathrm{AO}$ & Area of Operation \\
\hline $\mathrm{BC}$ & Battle Captain \\
\hline BDE & Brigade \\
\hline $\mathrm{BN}$ & Battalion \\
\hline $\mathrm{C} 2$ & Command, Control \\
\hline $\mathrm{C} 4$ & Command, Control, Communication, Computers \\
\hline CAX & Computer Assisted Exercise \\
\hline CCIR & Commander's Critical Information Requirements \\
\hline CDR & Commander \\
\hline C4ISR & Command, Control, Communication, Computers, Intelligence, Surveillance, Reconnaissance \\
\hline CBRN & Chemical, Biological, Radiological, Nuclear \\
\hline COA & Course of Action \\
\hline COP & Common Operational Picture \\
\hline COY & Company \\
\hline $\mathrm{CP}$ & Command Post \\
\hline $\mathrm{CPX}$ & Command Post Exercise \\
\hline DIV & Division \\
\hline DG & Deep Green \\
\hline DP & Decisions Point \\
\hline El & Emotional Intelligence \\
\hline $\mathrm{HQ}$ & Headquarter \\
\hline 12D2 & Intelligent, Interconnected, Distributed, Digital \\
\hline IED & Improvised Explosive Device \\
\hline 10 & Information Operations \\
\hline IPB & Intelligence Preparation of the Battlefield \\
\hline
\end{tabular}




\begin{tabular}{|l|l|}
\hline ISR & Intelligence, Surveillance, Reconnaissance \\
\hline MAC & Mission Assistance Computing \\
\hline MDMP & Military Decision Making Process \\
\hline MOE & Measures of Effectiveness \\
\hline MoND & Ministry of National Defence \\
\hline MOP & Measures of Performance \\
\hline NATO & North Atlantic Treaty Organization \\
\hline NCO & Non Commissioned Officer \\
\hline OE & Operational Environment \\
\hline OODA & Observe, Orient, Decide, Act \\
\hline PAF & Project Air Force \\
\hline PL & Platoon \\
\hline RAID & Real-time Adversarial Intelligence and Decision-making \\
\hline RM & Risk Management \\
\hline SBTM & Simulation Based Tactics Mining \\
\hline SWOT & Strengths, Weaknesses, Opportunities and Threats \\
\hline TOC & Tactical Operations Center \\
\hline TRL & Technology Readiness Levels \\
\hline USA & United States of America \\
\hline VUCA & Volatility, Uncertainty, Complexity, Ambiguity \\
\hline & \\
\hline
\end{tabular}

Author: $\quad$ LTC. Assoc. Prof. Paul Tudorache, PhD, born in 1981 in Buzău, Romania. Currently working as a Vice-Dean of Military Science Faculty at the "Nicolae Bălcescu" Land Forces Academy from Sibiu. He completed bachelor, master and doctoral studies in Military Sciences, the last two at the "Carol I" National Defence University. He posses high expertise of military operations, being deployed twice in Afghanistan (Operation Enduring Freedom - 2010, 2013). Also, he is the author of valuable books and scientific papers for the Military Science field, as well as a member of the scientific board of important conferences and magazines with national and international impact.

How to cite:TUDORACHE Paul. Applicability of Artificial Intelligence in Decision-Making for Land Forces. 2021, 30 (2), 039-054. ISSN 1210-3292 (print), 2336-2995 (online). Available at: www.vojenskerozhledy.cz 


\title{
Security force assistance advisory team - inputs and outcomes
}

\section{Poradenský tím asistencie bezpečnostným silám - východiská a výsledky}

\author{
Jaroslav Kompan, Michal Hrnčiar
}

Abstract: The article discusses the importance of security sector reform. The aim of the article is to present the potential of the concept of security sector reform as a NATO tool for prevention and resolution of internal conflicts on the real example of the deployed military advisory team of the Armed Forces of the Slovak Republic to the ISAF operation in Afghanistan. The authors focus on the orientation in the topic and correlation and causal anchoring of the topic in the introduction and the first part of the article. The second part presents the initial situation of the deployment of the Slovak advisory team in the ISAF operation. The third part and the discussion summarize lessons identified from the deployment of the advisory teams of the Armed Forces of the Slovak Republic. It also illustrates the conceptual framework, conditions and axioms for optimal and effective security force assistance within the efforts of the security sector reform as an important part of the stabilization and reconstruction concept.

Abstrakt: Článok pojednáva o význame reformy bezpečnostného sektora. Ciel'om článku je na reálnom príklade vyslaného príspevku OS SR v podobe vojenského poradenského tímu do operácie ISAF v Afganistane prezentovat' potenciál konceptu reformy bezpečnostného sektora ako nástroja NATO na prevenciu a riešenie vnútroštátnych konfliktov. Autori sa v úvode a v prvej časti článku zameriavajú na základnú orientáciu v problematike, korelačné i kauzálne ukotvenie témy. Druhá čast' predstavuje východiskovú situáciu nasadenia slovenského poradenského tímu do operácie ISAF. Tretia čast' a diskusia sumarizuje identifikované poznatky z nasadenia poradenských tímov OS SR. Tiež znázorňuje koncepčný rámec, podmienky a axiómy pre optimálnu a efektívnu asistenciu bezpečnostným silám $v$ rámci úsilia reformy bezpečnostného sektora ako dôležitej súčasti konceptu stabilizácie a rekonštrukcie.

Keywords: $\quad$ Security Sector Reform; Slovak Security Force Assistance Advisory Team; Afghanistan.

Kl'účové slová: reforma bezpečnostného sektora; Slovenský poradenský tím asistencie bezpečnostným silám; Afganistan. 


\section{INTRODUCTION}

The international community has undergone a major transformation since the end of the Cold War to meet the security and political challenges of the $21^{\text {st }}$ century. Achieving this goal effectively depends on the ability to respond quickly and effectively to a range of scenarios. ${ }^{1}$ Compared to the past, these apply not only to the conventional or irregular conflict but also to the prevention of conflicts by stabilization and reconstruction of the environment degraded by conflict. ${ }^{2}$ Ensuring stability is primarily based on the principle of proactive, respectively immediate deployment of international forces into Crisis response operations abroad. It is caused by globalization and technological progress, because "local" geographically limited areas of tension and instability can cause instability in the wider security environment without a timely solution, ${ }^{\mathbf{3}}$ including the security environment of the Euro-Atlantic area, ${ }^{4}$ or even with an impact on global stability. ${ }^{5}$

The fundamental approach of the international community towards maintaining long-term, ideally permanent security is to prevent the outbreak of violence by permanent presence of stabilizing forces in the crisis area, but also broad support for the social, economic or economic development of conflict-affected communities. ${ }^{6}$ It is the concept of Stabilization and Reconstruction (S\&R) as a tool primarily aimed at alleviating complex problems in fragile states that represents the dominant instrument used by the international community and the Alliance. The main purpose of this concept is to maintain, promote or restore stability in order to create the conditions for long-term sustainable peace.

Stabilization is focused on mitigation of the impact of the crisis and support legitimate political authorities, by those creating the conditions for long-term stability. It requires a comprehensive deployment of both civilian and military capabilities in order to reduce acts of violence, restore security and mitigate or even resolve social, economic and political disagreements. An integral part of the S\&R concept is also reconstruction, which is primarily aimed at rebuilding the physical infrastructure damaged in the conflict and government institutions degenerated by the crisis.

1 MAJCHÚT, Ivan. 2018. Deployability of Armed Forces in Irregular Warfare. In: The Knowledge-Based Organization - Management and Military Sciences. Sibiu: Nicolae Balcescu Land Forces Academy, 2018, pp. 130-136. ISBN 978-973-153-325-4. DOI: 10.1515/kbo-2018-0019.

2 SPILÝ, Peter; HRNČIAR, Michal. 2013. Vojenská taktika. 1. vyd. Liptovský Mikuláš: Akadémia ozbrojených síl gen. M. R. Štefánika, 2013. 272 p. ISBN 978-80-8040-471-0.

3 MAXIM, Milan. 2016. Miesto a úlohy ozbrojených síl pri predchádzaní a riešení konfliktov. In: Národná a medzinárodná bezpečnost' 2016. Liptovský Mikuláš: Akadémia ozbrojených síl gen. M. R. Štefánika, 2016, pp. 17-21. ISBN 978-80-8040-534-2.

4 SPIŠÁK, Ján a kol. 2018. Operační prostředí 2019: Implikace pro použitía rozvoj ozbrojených sil ČR 2019. Brno: Univerzita obrany v Brně, 2019. 18 p. ISBN978-80-7582-341-0.

5 HOFREITER, Ladislav; ŠIMKO, Juraj. 2007. Zdroje a oblasti konfliktov súčasného sveta. Liptovský Mikuláš: Akadémia ozbrojených síl gen. M. R. Štefánika, 2007, 95 p. ISBN 978-80-8040-330-0.

6 HRNČIAR, Michal. 2017. Možnosti zvýšenia efektivnosti operácii proti povstaniu [dissertation thesis]. Liptovský Mikuláš: Akadémia ozbrojených síl gen. M. R. Štefánika, 2017. 
The applicability of this concept is particularly suitable for internal conflicts characterized by a decline in the level of security and stability of the state caused by the consequences of a crisis or conflict. This situation creates a living space for the emergence and development of various opportunistic groups (non-state actors) ${ }^{7}$ and the subsequent promotion of their own interest, often even by irregular activities ${ }^{8}$, in an environment "not governed" by the government. Destabilizing actors have the greatest influence until Host nation (HN) itself is able to ensure its own internal and external security. Therefore, the urgent effort of the international community is to restore the local security sector through Security Sector Reform (SSR). "SSR features prominently in the mandates of United Nations peacekeeping operations, and is increasingly recognized as an essential element in post-conflict peacebuilding."9

The SSR is a cornerstone of other activities in building stable peace. It involves building and development of the capabilities of the HN security forces to independently perform tasks related to ensuring a secure environment in a crisis or conflict-affected state. This platform requires support from international community in the form of training, advice and assistance. SSR is a gradual process and HN's responsibility for its own security is not the result of an immediate change but a gradual increase in the capabilities of the security sector supported by international actors.

SSR should be managed in a complex and systematic manner with main emphasis: ${ }^{10}$

- to recognize and act on linkages between security sector reform and development,

- to be supported as part of a society-wide rather than a State-centric approach,

- to be provided for "South-South" cooperation on security sector reform,

- on promoting transparency, responsibility and participation to ensure the effective and accountable delivery of safety and security.

The SSR should be aimed at restoring or transforming all HN security actors and institutions, including their mission, responsibilities and activities. The ultimate goal is to achieve a state when the $\mathrm{HN}$ government is able to take responsibility for its own security while respecting human rights and laws, without the need for the support of international forces. Achieving this goal requires the expertise and sustainability of HN security forces at all levels of command and control.

7 VARECHA, Jaroslav. 2018. Revolúcia vo vojenských záležitostiach. In: Národná a medzinárodná bezpečnost' 2018. Liptovský Mikuláš: Akadémia ozbrojených síl gen. M. R. Štefánika, 2018, pp. 500-506. ISBN 978-80-8040-568-7.

8 HRNČIAR, Michal. 2017. Keystones of Irregular Warfare. In: The Knowledge-Based Organization Management and Military Sciences. Sibiu: Nicolae Bălcescu Land Forces Academy, Romania, 2017, pp. 150-154. ISBN 978-973-153-273-8. DOI: 10.1515/kbo-2017-0023

9 KI-MOON, Ban. A Word from:Mr. Ban Ki-moon Secretary-General [online]. [cit. 2021-04-01]. In: The United nations SSR prespective. Available at: <https://www.un.org/en/events/peacekeepersday/pdf/ securityreform.pdf>.

10 Identical letters dated 7 February 2013 from the Permanent Representative of Slovakia to the United Nations addressed to the Secretary-General, the President of the General Assembly and the President of the Security Council (A/67/740 S/2013/85) [online]. [cit. 2021-04-01]. Available at: <https://digitallibrary. un.org/record/744706? ln=en>. 
Despite of the fact that NATO SSR efforts are doctrinally based on UN guidelines, UN efforts are more focused to Africa continent. ${ }^{11}$ An example of the Alliance's involvement in resolving the crisis associated with the application of the SSR is e.g. Operation of the International Security Assistance Force (ISAF) in Afghanistan, which also included the Armed Forces of the Slovak Republic (AF SR) contribution represented by the Security Force Assistance Advisory Team (SFAAT). One of the key missions of the Slovak SFAAT in the ISAF operation was to provide advice on the training of a selected Security Force Assistance (SFA) object. This task included the transformation of the doctrinal environment and the systematic education and training of commanders, staffs and units of the Mobile strike forces (MSF) of the Afghan national army (ANA).

The subject of the article is to illustrate the influence of the international community on peace-building and the development of sustainable democratic government of the $\mathrm{HN}$. The aim of the article from "micro-level" perspective is to present the potential of the SFA concept as a tool for resolving emerging internal conflicts on a real example of the deployed contribution of the Armed Forces of the Slovak Republic in the form of SFAAT to the ISAF operation in Afghanistan. The main contribution of the article is a demonstration of the acquired theoretical knowledge and empirical experience of the authors from the deployment within the advisory teams of the Armed Forces of the Slovak Republic in the ISAF operation, namely the illustration of the conceptual framework, conditions, principles and axiom of success of the Security force assistance concept as a part of wider Security sector reform efforts. Because Security sector reform is an essential part of the international community's broad, comprehensive and integrated approach to crisis management.

The article is divided into four parts. The first part is devoted to defining the NATO SSR concept background and its link to the operation ISAF. The second part deals with the overall situation relevant for the deployment of the Slovak SFAAT in Afghanistan. The third part summarizes the knowledge gained by the authors and practical experience from the deployment in the ISAF operation, which are a suitable starting point for creating options to support the reform of the armed forces of the fragile state by relatively small contributions of small armed forces. The discussion presents proposals for axioms of optimal operation and effective deployment of military forces within the SSR with main focus on SFA.

\section{NATO CONCEPT OF SFA AS A PART OF WIDER SSR AND ITS CORRELATION WITH ISAF OPERATION}

The approach to the assessment of the security environment is an extremely sophisticated activity due to its complexity, the dynamics of its changes, instability and the

11 Security sector reform [online]. [cit. 2021-04-01]. Available at: <https://peacekeeping.un.org/en/ security-sector-reform>. 
intertwining of the influences of individual actors. ${ }^{12}, 13$ NATO's contemporary stabilization and reconstruction activities are mainly focused on developing the capabilities of NATO's partner countries. ${ }^{14}$ Through a comprehensive reform of the HN Armed Forces as part of the SSR, these operations enhance and develop security in the Euro-Atlantic area, but also outside it. The S\&R of post-conflict states creates the conditions for the development of international security and stability, acts preventively against the spread of conflicts to other regions and responds effectively to security challenges and threats in the $21^{\text {st }}$ century. ${ }^{15}$

Based on the experience from the SSR, it is visible that the SSR is a catalyst for the democratization of the state and at the same time a suitable tool for converting political decisions into practical support activities. Under the SSR, the military forces are mainly focus in particular on executing the Security Force Assistance, Stability Policing and Disarmament, Demobilization and Reintegration. In general, the SSR will ensure an improvement in the following areas of the security sector: ${ }^{16}$

- Democratization of the state - based on the transformation of security institutions and supervisory and governing bodies to support the development of democracy in a fragile state.

- "Good governance" - resulting from democratic elections in which politicians' representatives of citizens who are transparently elected, can promote the interests of the state and have control over the security sector of the state.

- Economic development - with regard to the security sector, which should have sufficient resources to ensure the external and internal security of the state, but these resources must be used transparently and responsibly.

- Internal and regional conflict prevention - requires effective management of internal tensions and conflicts and providing equal access to justice and security for all citizens of the state.

- Post-conflict reconstruction and recovery - based on the demobilization of combatants from the previous conflict and their reintegration into society and the integration of legitimate armed forces into the newly built security sector.

12 BUČKA, Pavel; PÁSTOR, Rudolf. 2019. Možné prístupy k hodnoteniu bezpečnostného prostredia. In: Národná a medzinárodná bezpečnost' 2019. Liptovský Mikuláš: Akadémia ozbrojených síl gen. M. R. Štefánika, 2019, pp. 96-105. ISBN 978-80-8040-582-3.

13 MUŠINKA, Miroslav. 2020. Možnosti hodnotenia bezpečnostných hrozieb. In: Vojenské reflexie, Vol. XV., No. 1 (2020), pp. 82 - 98. ISSN 1336-9202.

14 KOMPAN, Jaroslav. 2019. Aktuálny doktrinálny rámec operácií NATO na podporu mieru. In: Národná a medzinárodná bezpečnost' 2019. Liptovský Mikuláš: Akadémia ozbrojených síl gen. M. R. Štefánika, 2019, pp. 248-257. ISBN 978-80-8040-582-3.

15 KOMPAN, Jaroslav. 2018. Vonkajšia bezpečnost' Slovenskej republiky v kontexte novej bezpečnostnej stratégie. In: New Approaches to the National Security. Brno: Univerzita obrany v Brně, 2018, pp. 86-91. ISBN 978-80-7582-037-2.

16 KARKOSZKA, Andrzej. 2003. The Concept of Security Sector Reform. [online] 2013. [cit. 2020-12-21] Available at: <https://www.un.org/ruleoflaw/files/Karkoszka.pdf>. 
- Professionalization of security forces - with an emphasis on clearly defined responsibilities and tasks performed by individual security forces and compliance with the law.

Above all, the most important task for ISAF was to ensure the transformation of the Afghan National Security Forces to be able to independently and effectively ensure Afghanistan's external and internal security. Afghanistan after decades of violence ${ }^{\mathbf{1 7}}$ was dependent on international assistance because the state was independently unable to carry out full-fledged reform on its own without international aid. SFA was a key element of the Afghan defence reform, which was aimed at implementing development activities and supporting the sustainable capabilities of local armed forces and their associated institutions. ${ }^{18}$ SFA serves to develop responsible, sustainable, competent and credible security forces that are able to meet the security challenges of Afghanistan.

One of the most fundamental aspects of this assistance to the Afghan national security forces (ANSF) was to develop their ability to be fully responsible for security of Afghanistan. From the first operation of the coalition forces in Afghanistan in 2001 until the termination of the ISAF operation in 2014, the need to meet this expected end state was the priority. However, despite a general understanding of SSR at all levels of NATO command and control, the deployment and operations have not always been optimally planned. ${ }^{19}$

The course of the SSR, in the case of Afghanistan or even more Iraq, documents that if the SSR is affected by contradictory intentions of various regional and global security actors and it is not linked to national specifics of $\mathrm{HN}$, the whole system does not produce the desired end state. ${ }^{20}$ The SSR also possess the risk of uncoordinated intentions of various civilian agencies, which, while developing some part of the security sector, do not synchronize this development with other components. The main sources of SSR failure in a post-conflict state could be the following situations: ${ }^{\mathbf{2 1}}$

- Strong security forces, while democratic principles, civilian oversight and law enforcement are not yet in place in the state, can become a significant destabilizing factor, as power can be usurped by commanders of these forces at local, regional and national levels.

17 HOWK, C. Jason; HYDE, Andrew; PFORZHEIMER, Annie. 2020. Four Lessons for Security Sector Reform in Afghanistan [online] 2013. [cit. 2021-04-01]. Available at: <https://www.usip.org/publications/2020/10/ four-lessons-security-sector-reform-afghanistan>.

18 NATO. 2016. AJP-3.16 Allied Joint Doctrine for Security Force Assistance. Brussels: NSO, 2016.

19 MOERBE, Wesley. 2013. Early Mistakes with Security Forces Advisory Teams in Afghanistan. In: Military Review Journal (May-June). [online] 2013. [cit. 2020-12-21]. Available at: <https://www.armyupress.army. mil/Portals/7/militaryreview/Archives/English/MilitaryReview_20130630_art007.pdf>.

20 KOMPAN, Jaroslav. 2018. Koncepčný rámec nasadenia slovenského poradenského tímu v operácii ISAF Afganistan v roku 2014. In: Národná a medzinárodná bezpečnost' 2018. Liptovský Mikuláš: Akadémia ozbrojených síl gen. M. R. Štefánika, 2018, pp. 173-178. ISBN 978-80-8040-568-7.

21 SEDRA, Mark. 2007. Security Sector Reform in Afghanistan and Iraq: exposing a concept in crisis. In: Journal of Peacebuilding and Development, Vol. 3., No. 2(2007), pp.7-23. Available at: <https://gsdrc.org/ document-library/security-sector-reform-in-afghanistan-and-iraq-exposing-a-concept-in-crisis/>. 
- Implementation of short-term solutions at the expense of the long-term development of democratic and accountable security forces and judicial institutions, such as the provision of equipment without an education and training system.

- Focusing on addressing the consequences of conflict instead of developing long-term mechanisms to address the root causes of conflict.

- The late establishment of a judicial system, where law enforcement agencies detain perpetrators of illegal acts but there is no fair and independent judiciary to sanction them.

- Usurpation of the SSR by only one actor who promotes his own security interests through the SSR, regardless to the needs of HN.

\section{SLOVAK SECURITY FORCE ASSISTANCE ADVISORY TEAM -} OVERALL SITUATION AND INPUTS TO THE DEPLOYMENT

ISAF coalition forces have been deployed in Afghanistan since December 2001 to assist Government of the Islamic republic of Afghanistan (GIRoA) in maintaining a security environment in and around Kabul. ${ }^{22}$ NATO took the lead over ISAF operation in Afghanistan, on $11^{\text {th }}$ August 2003. The United nations Security council (UN SC), by Resolution no. 1510, extended ISAF's mandate to the whole of Afghanistan, on $13^{\text {th }}$ October 2004.

The Alliance agreed to shift to the 4th phase "TRANSITION" of the ISAF operation, with the aim of gradually transfer responsibility for Afghanistan's security and governance to its military and security authorities at the NATO Summit in Lisbon, in November 2010. ANSF began to take the lead in security operations in almost all regions of Afghanistan, at the end of 2011 and the beginning of 2012. The main intent of this effort was to allow the withdrawal of ISAF units from the Afghanistan by the end of $2014 .{ }^{23}$ To achieve this goal, ISAF introduced the concept of SFA. ${ }^{24}$

SFA concept for ISAF operation was approved by the ISAF Commander in late 2011 and also approved by NATO in early 2012. SFA was primary tool in the ISAF operation's "TRANSITION" phase and an element that ensured the successful transfer of authority to ANSF until the end of 2014. Because the Alliance approved a declaration on the termination of the ISAF operation by $31^{\text {st }}$ December 2014 and on the continuation of the NATO-Afghanistan partnership beyond 2014, at the NATO summit, in May 2012. The SFA concept was implemented mainly in the form of advisory during the basic training and reconciliation of local units and then as part of their preparation for the independent execution of operations, in 2012-2014.

22 ISAF's mission in Afghanistan (2001-2014). [online] 2015. [cit. 2021-01-21]. Available at: <https://www. nato.int/cps/en/natohq/topics_69366.htm>.

23ISAF Joint Command (IJC). Operations Plan 1391, Annex F - Security Force Assistance, 10 April 2012.

24 KELLY, Terrence; BENSAHEL, Nora; OLIKER, Olga. 2011. Security Force Assistance in Afghanistan: Identifying Lessons for Future Efforts. Santa Monica: RAND Corporation, 2011. ISBN 978-08-3305-211-7. [online]. [cit. 2021-04-01]. Available at: <https://www.rand.org/pubs/monographs/MG1066.html>. 
The SFA concept has become a method used by coalition forces in Afghanistan to support the fulfilment of their operational tasks in partnership with the ANSF. This concept included multiple activities, in particular, the Organize, Train, Equip, Rebuild - build, and Advise and assist (OTERA), thus increasing the operational efficiency of the ANSF. For NATO, this meant reducing the number of coalition forces deployed in Afghanistan, but on the other hand increasing the contribution to assistance to HN security forces.

Despite all efforts, insurgent structures in Afghanistan have still not been completely curtailed. The basic premise that applies to the implementation of the SFA concept in Afghanistan was that the ANSFs have and have been carrying out, in particular, counterinsurgency (COIN) operations. This means that the whole focus of the SFA concept must be on supporting the ANSF's capacity and capabilities to conduct COIN operations, while reducing the risks arising from the operating environment.

However, this requires a thorough understanding of the specifics of COIN operations in all areas (planning, sustainability, intelligence, etc. $)^{25}$ and a consistent transfer of this understanding to the $\mathrm{HN}$ unit. The actual execution of operations took place without the intervention of advisors, which ensured an increase in the credibility of the ANSF, especially for the local population. ${ }^{26}$

The Armed Forces of the Slovak Republic have been actively involved in the ISAF operation on the basis of a resolution of the National Council of the Slovak Republic (NC SR), since June 2004. As a consequence of NATO summit in Lisbon, in November 2010, Slovak Republic demonstrated its eminent interest on the transformation of the ANSF and this interest was confirmed by deployment of the SFAAT, in 2014. The NC SR, by its resolution no. 113 approved the deployment of the SFAAT to support the critical priority of the ISAF operation. ${ }^{27}$

The decisive task of Slovak SFAAT was to provide assistance to the Afghan National Army (ANA) mobile strike force. This required support to ANA units, comprehensive advisory in several provinces with the ability to be deployed throughout Afghanistan. But there also had to be a change of mindset and the abandonment of the mentoring system, which required the continued presence of mentors within Afghan troops. Rather, the concept of advisory focused on supporting already trained HN security forces and developing their combat potential by providing advisory, assistance, training, and systemic development of critical capabilities. ${ }^{28}$ The advisory was normally executed at the three levels (1-2-3) and Slovak SFAAT was tasked to execute all of them:29

25 HRNČIAR, Michal. 2018. The Counter Insurgency Operating Environment. In: The Knowledge-Based Organization - Management and Military Sciences. Sibiu: Nicolae Bălcescu Land Forces Academy, 2018, pp. 87-92. ISBN 978-973-153-325-4. DOI: 10.1515/kbo-2018-0013

26KOMPAN, Ref. 20.

27 Uznesenie Národnej rady Slovenskej republiky č. 113/2013 k návrhu na vyslanie, predľ́zenie času vyslania a ukončenie času vyslania príslušníkov ozbrojených síl Slovenskej republiky vo vojenskej operácii ISAF. Bratislava: NR SR, 2013.

28Report on Enhancing Security and Stability in Afghanistan. Washington: Department of Defense, 2015.

29 Afghan War News. Security Force Assistance (SFA) in Afghanistan. [online] 2014. [cit. 2021-01-21]. Available at: <http://www.afghanwarnews.info/sfa/afghanistansfa.htm>. 
- Level 1 - the highest level of advisory. The advisory unit performs advisory of the HN unit on a daily basis. The SFAAT is located on the same base (or a very close coalition base) and is ready to respond immediately to the demands of the domestic unit, including the execution of combined operations.

- Level 2 - The advisory unit cooperates with the domestic eligible unit and monitors only compliance with the standards and the development of competencies set by the ANSF command. SFAAT may also carry out such activities for the benefit of several domestic units, as daily supervision is not required.

- Level 3 - the least effective form of advisory. Contact with the home unit is carried out by advisors only by telecommunication means, physical visits are limited to the organization of joint conferences, where the $\mathrm{HN}$ units independently document the level of their development.

The key factors that influenced the optimal performance of advisory mission were extreme security situation and demanding weather and terrain conditions. The security situation in Afghanistan was extreme, in 2014. Insurgent attacks were carried out at the military bases of coalition and $\mathrm{HN}$ security forces, as well as at units executing mission outside the bases. Very demanding issue were incidents of insurgent infiltration into coalition bases and attacks at coalition forces by members of the ANSF (so called "Green on Blue attacks"). These incidents were very common due to the inadequate attitude of coalition forces to the ANSF, as well as the insurgents' ongoing ability to infiltrate the ANSF. Non-kinetic activities of the insurgents were aimed at intimidating the local population and an information campaign. ${ }^{30}$

Another significant factor was that the SFA object - military unit was a newly created unit. It was established in the second half of 2013. This meant that it was still in the phase of full mentoring and at the beginning of SFAAT's activities it was still without combat and operational experience. Commanders were moved from another ANA units and have no knowledge of newly built ANA doctrinal system, soldiers newly recruited. ${ }^{\mathbf{3 1}}$

All the above-mentioned factors significantly influenced the deployment. In particular, the extreme security situation significantly "tied the hands" of advisors in the implementation of the established SFA concept.

30 KOMPAN, Ref. 20.

31 KOMPAN, Jaroslav. 2018. Výcvik manévrového úderného práporu Afganskej národnej armády slovenským poradenským tímom v operácii ISAF Afganistan v roku 2014. In: Národná a medzinárodná bezpečnost' 2018. Liptovský Mikuláš: Akadémia ozbrojených síl gen. M. R. Štefánika, 2018, pp. 179-184. ISBN 978-80-8040-568-7. 


\section{SLOVAK SECURITY FORCE ASSISTANCE ADVISORY TEAM - LESSON IDENTIFIED FROM DEPLOYMENT}

\subsection{SFA object must be suitable and perspective for long-term development}

SFA object training and advising itself must directly support the competencies that guarantee the vigorous suppression of hostile activities, but also enhance the natural confidence of the local population (as part of the "Minds and Hearts" approach). ${ }^{32}$ It is therefore necessary to focus advice in particular on rapid decision-making, leaders integrity and, in addition, as consequence of the security situation, on developing the ability to perform dynamic maneuvers and ensure combat projection throughout the area of operations with an emphasis on maintaining a high tempo, survivability on the battlefield with extreme occurrence of explosive threats. Of course, a crucial element is also the development of the skills to sustain the operations, especially in a way of logistic support and equipment care. Without those, unit combat readiness is limited. ${ }^{33}$

When selecting a suitable SFA object, it is advisable to perform a thorough analysis, which results in a correctly identified SFA object. The analysis must include, in particular, an assessment of the future impact of a particular military component or subsystem on the overall security in a specific region or area or for larger components throughout the country. ${ }^{34}$ Mobile strike forces are preferable due to their capability of conducting security operations over a larger geographical area. Additionally, there is higher probability of better equipment which will allow better capability projection and more flexible continuous interaction with the population. ${ }^{35}$ At the same time, it is likely that the leaders and also units' members will meet higher personnel standards in comparison with other units and this creates conditions for long-term and sustainable development. ${ }^{36}$ The longitudinal issue is that SFA providers and their HN counterparts should plan a long-term transition to sustainable force. Specifically, when the insurgency presents long-term challenge as in Afghanistan. ${ }^{37}$

32 TURAJ, Milan. 2018. Zhodnotenie aktuálneho stavu bojového použitia predsunutých leteckých navádzačov v podmienkach Ozbrojených síl Slovenskej republiky. In: Vojenské reflexive. Vol. XIII., No. 2 (2018), pp. 164 -174. ISSN 1336-9202.

33 KOMPAN, Ref. 31.

34 KOMPAN, Jaroslav. 2019. Using the SWOT analysis of the external security of the Slovak republic as a basis for defense planning. In: Security Forum 2019. Banská Bystrica: Univerzita Mateja Bela, Interpolis, 2019, pp. 59-66. ISBN 978-80-973394-1-8.

35 Afghan War News. ANA Mobile Strike Force (MSF). [online] 2013. [cit. 2021-01-21]. Available at: <http:// www.afghanwarnews.info/army/mobilestrikeforce-msf.htm>.

36 Report on Enhancing Security and Stability in Afghanistan. Ref. 28.

37 KELLY et al., Ref. 24. 


\subsection{SFA object has its own priorities but those needs to be assessed for compliance with HN standards}

"There was a very real threat the army would not be able to adapt fast enough in capability and size to stop the nation from returning to a civil war. This echoes some of today's concerns, especially if spoilers and splinter groups work to stop peace from fully taking hold." 38 The task of the advisors was to carry out continuous assessment of the SFA object capability development, which ensured that the SFA object's training met ANA standards and resources were used effectively. The most fundamental deficiencies were assessed mainly in the capabilities of individuals, units' tactics, and decision-making to execute and sustain the operations in the area of operations contaminated with explosive threats. This deficiency influenced evaluation in most other areas. ANA General Staff identified this deficiency as crucial capability to be developed by advisors in the mission-essential tasks list. At the same time, given the ANA's casualties statistics, improving the SFA object's capabilities to reduce the impact of explosive threats also increased the ability to protect forces and survive on the battlefield. The toughest challenge, then, was to harmonize the activities of all subordinate components of the SFA object so that as a whole it would achieve full operational readiness - Full operational capability (FOC) within the timeline set by the superior headquarters of ANA. These areas were critical to achieving the capabilities that were designed and expected from all SFA objects and fully followed the expected final state of the "TRANSITION" phase of the ISAF operation. ${ }^{39}$

A critical element of advising efforts was also to support the SFA object's relations with local authorities and the civilian population so that it was identified as a natural, responsible and proactive "protector" of the civilian population against insurgent activities. This comprehensive activity therefore required advisors to support the development of the SFA object and to be as present and visible as possible during training and operations, but not to take the initiative so that Afghan commanders come to the fore. ${ }^{40}$

Furthermore, advisors should understand not only how to deploy own national and coalition forces but also how to develop HN forces and employ them with coalition forces in such a way that both $\mathrm{HN}$ and national interests are met. ${ }^{41}$

The training was carried out not only at the bases, but combined operations with coalition partners from NATO were also identified as advantageous training conditions, where the SFA object firstly performed supporting tasks and gradually took the initiative in order to be self-sufficient force. ${ }^{42}$

38 HOWK et al., Ref. 17.

39 KOMPAN, Ref. 31.

40 KOMPAN, Ref. 31.

41 KELLY et al., Ref. 24.

42 SEDRA, Mark. 2014. An Uncertain Future for Afghanistan's Security Sector. In: Stability: International Journal of Security and Development, 3(1), p. Art. 35, pp. 1-16. DOI: http://doi.org/10.5334/sta.ei 
The advisory activities of the Slovak SFAAT thus fully developed the set areas so that the SFA object would be able to independently manage and develop these capabilities before the set deadline for achieving the FOC. Of course, the whole training concept had to support ANA's strategic training concept, the main motto of which is "Train the way you fight!". 43

\section{DISCUSSION}

The Slovak SFAAT managed to achieve a fully capable evaluation with the SFA object in a comprehensive area through comprehensive training and the use of training opportunities. At the same time, the SFA object became completely independent and self-sufficient in the planning of training and subsequent deployment in military operations. Due to the end state projected by the ANA General Staff, the SFA object was able to maintain its capabilities independently, thus confirming its readiness to conduct independent operations without the participation of advisors and taking responsibility for security in a selected region of Afghanistan. ${ }^{44}$ Simplified conceptual model of generic SFA efforts is visible on the Figure 1.

\begin{tabular}{|c|c|c|c|c|c|c|}
\hline $\begin{array}{l}\text { Unit } \\
\text { establishment } \\
\text { Handover of } \\
\text { the equipment } \\
\text { and weaponry }\end{array}$ & $\begin{array}{l}\text { Basic combat } \\
\text { drills } \\
\text { Training centre }\end{array}$ & $\begin{array}{c}\begin{array}{c}\text { Tactical } \\
\text { training }\end{array} \\
\text { Training centre }\end{array}$ & $\begin{array}{c}\begin{array}{c}\text { Progress } \\
\text { assessment }\end{array} \\
\begin{array}{c}\text { Training } \\
\text { centre }\end{array}\end{array}$ & $\begin{array}{c}\text { Operational } \\
\text { training } \\
\text { Area of } \\
\text { operations - } \\
\text { District of } \\
\text { Afghanistan }\end{array}$ & $\begin{array}{c}\text { Taking } \\
\text { responsibility } \\
\text { Area of } \\
\text { operations - } \\
\text { District of } \\
\text { Afghanistan }\end{array}$ & $\begin{array}{l}\text { Ability to } \\
\text { lead SFA for } \\
\text { own HN } \\
\text { units }\end{array}$ \\
\hline 9 weeks & ori & $\begin{array}{c}21 \\
\text { weeks }\end{array}$ & & $\begin{array}{c}3-9 \\
\text { months }\end{array}$ & $\begin{array}{l}\text { ndependently } \\
12-24 \\
\text { months }\end{array}$ & ??? years \\
\hline
\end{tabular}

Figure 1: Implementation of SFA into the life cycle of the HN military unit

Given the experience of deployment of the Slovak SFAAT in the ISAF Afghanistan operation, it could be claimed that any effort focused on development of the capabilities of $\mathrm{HN}$ units requires compliance with certain standards. Due to their universal validity, these standards could be called axioms of effective SFA and are based on 15 principles of SFA valid for operation ISAF Afganistan: ${ }^{45}$

(1) One SFA object requires one SFAAT - in order to maintain a continuum in advisory, but also to establish relationships that ensure mutual understanding and comprehension.

43 Afghan National Army Field Manual ANA 0-3.1. Train the Force. Kabul. 2013.

44 KOMPAN, Ref. 31.

45 ALLEN, John. 2012. 15 principles of SFA [online]. [cit. 2021-04-01]. Available at: <https://afghanwarnews. info/sfa/15principlesofsfa.htm>. 
(2) SFA is not just a task for SFAAT - it is performed by all units coming into contact with HN units.

(3) When advising to the SFA object, implement such training methods that will be not only acceptable but also successful. ${ }^{46}$

(4) The SFA object may fail - therefore it is necessary to set the right indicators that can identify negative impacts in time.

(5) The SFA object should be visible - especially with regard to the interaction with the local population, which should perceive the SFA object as a guarantor of security. Therefore, it is better for the HN unit to do something "good enough" than for the coalition unit to do it perfectly.

(6) Requirements and tasks from the HN headquarters have priority - because the SFA object is not established as a coalition unit, but as part of the HN security forces, which have the right to use it in accordance with their own directives.

(7) Understand the cultural specifics of a particular area - understand that SFAs are performed in a fragile state and cultural differences cannot divide or bring about conflicts.

(8) SFA must be a constantly flexible response tool - responsive to the needs of HN and the development of the $\mathrm{HN}$ security environment.

It follows from the above that by application and constant and thorough evaluation of the above axioms it is possible to achieve the overall success of the SFA, and thus support the overall success of SSR and its projected target state, i.e. stability, consistently and long-term sustainable peace in a fragile state.

\section{CONCLUSION}

None of the major international peacekeeping operations or peacekeeping missions has yet achieved the required political goal of transforming the target $\mathrm{HN}$ into a stable, independent and prosperous liberal democracy. ${ }^{47}$ One such example is the Afghanistan where the internationally supported stabilisation and state-building efforts have not been a success. ${ }^{48}$ But this was relevant initially before the operation ISAF has made a significant contribution to the effective transformation of the ANSF, with its SFA concept.

The security policy of the Slovak Republic is guided not only by narrowly defined territorial interests, but also by the principles of solidarity with the Allies. The Slovak Republic has the potential to participate in the efforts of the international community

46 ZAHRADNÍČEK, Pavel; RAK, Luděk. 2020. Modern Teaching Methods Implemented in Training of Students of University of Defence. In: International Journal of Latest Research in Science and Technology, Vol. 9, Issue 2 (2020), pp. 13-17. ISSN 2278-5299.

47 DOPITA, Tomáš. 2011. Liberální vládnutí buduje liberální mír. Armádní a policejní reforma v Bosně a Hercegovině. In: Mezinárodní vztahy, Vol. 46, No. 2 (2011), pp. 35-56. ISSN 2570-9429 (Online).

48 AYUB, Fatima; KUOVO, Sari; WAREHAM, Rachel. 2009. Security sector reform in Afghanistan - Country case study: Afghanistan. Brussels: IFP Security Cluster, 2009. [online]. [cit. 2021-04-01]. Available at: <https://www.ictj.org/sites/default/files/ICTJ-Afghanistan-Security-Reform-2009-English.pdf>. 
in managing and resolving crisis situations. These efforts may include prevention, the deployment of military and civilian assets to address or to solve the consequences of conflicts and crises, as well as stabilization efforts, reconstruction and subsequent sustainable development. For this purpose, the Armed Forces of the Slovak Republic must be able to carry out specific activities to achieve the objectives in accordance with the strategic ambitions of the Slovak Republic. ${ }^{49}$

If the Slovak Republic wants to promote its security interests, it should address not only local or regional security threats or challenges but it must also support development of the fragile states security sector as a prevention. ${ }^{50}$ The ambition of the Slovak Republic to deploy SFAAT to the ISAF operation in 2014 resulted from the shift of the ISAF operation to the "TRANSITION" Phase and it contributes to the success of wider Alliance SSR efforts in Afghanistan. The Armed Forces of the Slovak Republic have clearly demonstrated their ability to contribute to the development of the ANSF and that they are a valuable coalition partner for the rest of the Alliance.

The deployment of SFAAT brought many lessons identified for the Armed Forces of the Slovak Republic and many of them were applied to training or to normative documents. All of these lessons could simplify the preparation for other similar deployment in the future. For example, in this case lessons identified served as a basis for the preparation of advisory teams for the NATO Training Mission in Iraq (NTM-I).

At the same time, however, it should be assumed that regardless of the country of deployment it is always necessary to select SFAAT members very carefully. The reason is the high risk of endangering the lives of members of the Armed Forces of the Slovak Republic and the need to manage cultural, religious, ethnic and geographical specifics ${ }^{51}$ to minimize so called "GREEN on BLUE" incidents. 52

Authors: $\quad$ Major Jaroslav Kompan, was born 1982. He graduated the Faculty of Land Forces of the Armed Forces Academy in Liptovský Mikuláš in 2005. He is external doctoral student of the Department of Security and Defence, specialization Defence and Military. He works as an assistant at Military Tactics and Operational Art Department at the Armed Forces Academy of General M. R. Štefánik in Liptovský Mikuláš. He has been assigned as a military advisor to various Afghan National Army combat units. He specializes in field of research of international security, operational art, military engineering. He is author of wide portfolio of scientific and professional articles in domestic and foreign journals.

49 ANDRASSY, Vladimír. 2019. Slovenská republika v operáciách NATO po summite vo Varšave. In: Politické vedy, Vol. 22, Issue 1 (2019), pp. 80-107. ISSN 1335-2741, ISSN 1338-5623.

50 KOMPAN, Ref. 15.

51 HRNČIAR, Ref. 25.

52 KOMPAN, Ref. 20. 
Major Michal Hrnčiar, PhD, was born 1980. He graduated the Faculty of Land Forces of the Military Academy in Liptovský Mikulás in 2004. He completed his doctoral studies at the Academy of the Armed Forces of General M. R. Štefánik, specialization National and International Security, in 2017. He works as an assistant professor at Military Tactics and Operational Art Department at the Armed Forces Academy of General M. R. Štefánik in Liptovský Mikuláš. He has been deployed twice to UNFICYP. He specializes in field of research of military arts and security. He is co-author of a textbook, a monography and the wide portfolio of scientific and professional articles and studies in domestic and foreign journals.

How to cite:KOMPAN, Jaroslav and Michal HRNČIAR. Security force assistance advisory team - inputs and outcomes. Vojenské rozhledy. 2021, 30 (2), 055-069. ISSN 1210-3292 (print), 2336-2995 (online). Available at: www.vojenskerozhledy.cz 


\section{Recenze monografie autora}

\section{PROCHÁZKA, Josef a Pavel NEČAS. Př́stupy k tvorbě bezpečnostních a obranných strategií.}

Banská Bystrica: Univerzita Mateja Bela v Banskej Bystrici, Fakulta politických vied a medzinárodných vztahov, 2020. ISBN 978-80-557-1656-5.

\section{Vladimír Karaffa}

Fenomén bezpečnosti je $v$ dnešním nepředvídatelném světě předmětem zvyšujícího se zájmu společnosti a prvoradou programovou oblastí téměř všech politických stran a hnutí. Není divu, že okolnosti a dopady strategického rízení bezpečnosti jsou v demokraciích jednou z nejvíce kritizovaných oblastí v rámci politického soupeření parlamentních i mimoparlamentních stran a hnutí a ve středu zájmu medií, jak to potvrzuje i aktuální řešení koronavirové pandemie.

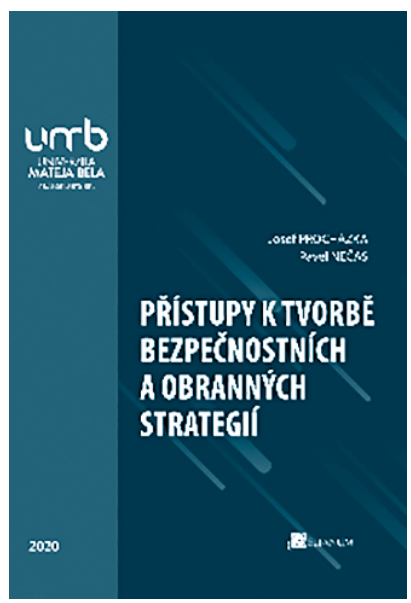

Vědecká monografie autorů doc. Ing. Josefa Procházky, Ph.D. a prof. Ing. Pavla Nečase, Ph.D., MBA, která byla vydána nakladatelstvím Belianum pod patronací Univerzity Mateja Bela v Banské Bystrici začátkem roku 2020, se strategickému řízení bezpečnosti věnuje do hloubky, s vědeckou systematickou důsledností. Tematicky je zaměřena na problematiku řízení bezpečnosti na strategické úrovni, to znamená na úrovni vlády a ústředních správních úřadů státu, zejména ministerstva obrany.

Z obsahu i dikce textu je zřejmé, že doc. Procházka je zkušeným odborníkem, který v monografii zúročil vlastní zkušenosti z práce na Ministerstvu obrany ČR a na velitelství Severoatlantické aliance $v$ Bruselu. Problematice strategického řízení se dlouhodobě věnuje i v rámci své vědecko-pedagogické činnosti v Centru bezpečnostních a vojenskostrategických studií Univerzity obrany.

Prof. Nečas je rovněž uznávaným odborníkem, jenž během své bohaté kariéry získal řadu zkušeností v rámci své činnosti v Ozbrojených silách Slovenské republiky, na Ministerstvu obrany SR, $v$ NATO Defence College $v$ Římě, při působení ve stálém zastoupení $S R$ v EU v Bruselu a ve vojenském školství. V současné době je profesorem na katedře bezpečnostních studií Fakulty mezinárodních vztahů Univerzity Mateja Bela v Bánské Bystrici.

Vědecká monografie s názvem Př́stupy $k$ tvorbě bezpečnostních a obranných strategií svým rozsahem patří mezi relativně méně rozsáhlé publikace, což nelze říct o jejím 
obsahu. V koncentrované podobě shrnuje běžné i méně dostupné informace o strategickém řízení obrany a o metodách a formách tvorby strategických dokumentů a prezentuje poznatky nejlepší praxe (best practise) v oblasti strategického řízení a tvorby bezpečnostních strategických dokumentů v ČR, NATO, EU, Kanadě, Norsku a rovněž USA a Srbsku. Jedná se o země, kde autoři působili v rámci svých pracovních nebo studijních pobytů a měli možnost tuto problematiku podrobně studovat a konzultovat s místními odborníky. Významná je část monografie věnována analýze současné praxe tvorby bezpečnostních strategických dokumentů v ČR a částečně i na Slovensku. V závěrečné části publikace autoři představuji svá doporučení, jak optimalizovat strukturu a obsah strategických dokumentů v oblasti obrany.

Přestože monografie ve svém názvu a rovněž v některých obsahových formulacích deklaruje, že řeší prrístupy $k$ tvorbě bezpečnostních a obranných strategií, ve skutečnosti se zaměřuje téměř výhradně na oblast obrany jako na jeden ze sektorů bezpečnosti, který se $v$ pojetí tzv. rozšířeného konceptu bezpečnosti nebo také kodaňské školy zaměřuje na sektor vojenské bezpečnosti. Ostatní sektory (politická, environmentální, societární, ekonomická bezpečnost) autoři ponechávají stranou. Je nutno poznamenat, že slovní spojení „bezpečnost a obrana“ se ale v praxi stále, čistě z pragmatických důvodů, používá. Vyjadřuje tak vertikální přesah obranné politiky do vyšších pater bezpečnostní politiky, která má jak národní a nadnárodní, tak i širší mezinárodní rozměr.

Monografie ve třetí kapitole, věnující se strategickému rámci tvorby strategii, stručně vystihuje genezi vývoje současné strategické kultury v oblasti bezpečnosti. Je důležité, že postihuje realitu současného bezpečnostního prostředí, která je podstatou postupného přechodu z plánování obrany proti jednoznačně definovanému protivníkovi $\mathrm{k}$ současným plánovacím přístupům založeným na absenci základních plánovacích předpokladů, zejména neexistenci konkrétního protivníka a dominanci nejistoty.

Ve čtvrté části monografie shrnují autoři základní teoretické přístupy ke strategickému rízení obrany, jeho formám, metodám a metodologii tvorby strategií a strategických dokumentů. Od obecných principů postupně přechází k zásadám formulování bezpečnostní politiky státu a vrcholových bezpečnostních dokumentů, zejména „(národní) bezpečnostní strategie“. Je nutno ocenit, že problematiku pojímají jak ze systémového hlediska (jako soubor subsystémů, prvků, faktorů a procesů), tak i z hlediska procesního (jako posloupnost vertikálně i horizontálně provázaných kroků a opatření). Domnívám se však, že zde mohli autoři daleko více zdůraznit úlohu vedoucích pracovníků v procesu formulace strategií a rovněž zvýraznit cyklický charakter strategického řízení a tvorby a aktualizace strategických bezpečnostních dokumentů.

Část věnována dokumentům strategického řízení, která má charakter dílčí analýzy, by si zasloužila podrobnější rozpracování. S použitými argumenty bude určitě souhlasit každý odborník, který byl ve své praxi do procesu jejich tvorby zapojen. Pro nezainteresovaného čtenáře bude zřejmě řada faktů přiliš stručná a argumentačně málo podložená. Př́kladem je výčet problémů, jako je "unáhlené uzavírání diskusi“, „odmítnutí nebo podcenění perspektivních technologií..." "zneužiti historických paralel“ nebo "zkostnatělé představy o budoucí krizové situaci“. Ty by si zasloužily podrobnější rozbor, který by zřejmě překročil rámec této publikace a nutně by se musel zabývat i sociologickými, politologickými a psychologickými aspekty řídicí praxe vrcholových představitelů v současné 
demokracii. Stejně tak i úvahami nad tím, jak tyto problémy překonat. Jednalo by se však již o úplně jinou publikaci.

Myšlenkové těžiště monografie se koncentruje kolem prístupu k plánování podle schopností v podmínkách nejistoty, a to je jejím velkým kladem. Zejména je přesvědčivě zdůvodněna nezbytnost využívání operačních scénářů jako důležitého podkladu pro objektivizaci strategických rozhodnutí a požadavků na schopnosti ozbrojených sil. Tvorba scénářů je etapou tvorby strategických rozhodnutí, která se i přes svoji nespornou důležitost v praxi jen těžce prosazuje, často je ignorována a není ani správně pochopena.

Významným prínosem autorů je přehled metod strategického řízení s doporučením, jak je využívat $v$ procesu tvorby bezpečnostních a obranných strategii. Základním sdělením je skutečnost, že se $v$ praxi nelze upnout na jedinou metodu, ale je nutné metody tvưrčím způsobem kombinovat. Je potřeba ocenit, že se monografie věnuje způsobům hodnocení a řešení nedostatků ve schopnostech. Je to jedna z metod prioritizace opatření ke zvýšení schopností a objektivizace požadavků, např́klad na akviziční aktivity, a tím i eliminace různých subjektivně prosazovaných projektů.

Významnou metodou, která se v publikaci často opakuje, je metoda DOTPMLFI. Protože se jedná až o módní, v praxi často prosazovanou a používanou metodu, zasloužila by si v publikaci větší prostor. Metodu Ize používat dvojím způsobem - bud' na celý komplex opatření, nebo na jeho dílčí fragmenty. Například při zavedení nového bojového systému se nezkoumá, zda je pro něj dostatek potřebných listinných či elektronických dokumentů, jak to autoři nepřesně interpretují, ale jak tento systém ovlivní operační a taktické zásady činnosti vojsk (doktrinální zásady), které se pak mohou rozpracovat v relevantních doktrinálních dokumentech.

Návrhová část monografie je postavena na vlastním mentálním modelu strategické adaptace, jenž poskytuje analytický rámec pro systematické hodnocení prostředí a jeho dopadů na ozbrojené síly, politické usměrnění jejich rozvoje, stanovení nezbytně potřebných schopností a identifikaci racionálních opatření k jejich dosažení v rámci disponibilních zdrojů. Model přitom pracuje se čtyřmi oblastmi: strategickou analýzou, politickou doménou, strategickým plánováním a vojenskou doménou. Autoři zdůrazňuji, že zásadní je politická doména, kam patří i formulace společenské objednávky veřejné služby, zajištění obrany, která závisí mimo jiné i na míře akceptace bezpečnostních hrozeb a rizik, a tím i rizika, že případná bezpečnostní hrozba nebude eliminována. Je přitom nutno ocenit, že autoři zvýrazňují roli vojenské domény (zejména resortu obrany a ozbrojených sil) v procesu prípravy kvalitních a politicky akceptovatelných podkladů pro tvorbu politického zadání.

Velmi přehledně publikace předkládá metodiku tvorby strategických dokumentů, která vychází z teorie strategického řízení, poznatků nejlepší praxe a zvláště závěrů, ke kterým se autoři dopracovali v předchozích částech textu. Nabízí se možnost tuto metodiku podrobněji rozpracovat a využít ji nejen pro potřebu vzdělávání vedoucích pracovníků resortu obrany, ale i pro zpracovatelské týmy zapojené do tvorby strategických dokumentů.

Návrh autorů na strukturu dokumentů strategického rrízení nepřináší ve srovnání se současným stavem zásadní změny. Lze souhlasit se změnou některých názvů dokumentů (např. „dlouhodobý výhled...“ na „dlouhodobý záměr...") nebo možnost nahrazení "obranné strategie“ „bílou knihou“ a tím i s nezbytnou změnou jejich obsahu. Stejně tak 
se Ize ztotožnit s potřebou tvorby operačních koncepcí použití ozbrojených sil, které by měly být zásadním východiskem pro formulaci schopností a tvorbu doktrinálních dokumentů. Dílčí strategie hlavních organizačních prvků a funkční a průřezové strategie (koncepce) se v praxi českého ministerstva obrany a generálního štábu zpracovávají, přestože přetrvávají problémy v synchronizaci jednotlivých dokumentů.

Je škoda, že monografie nevěnuje větší pozornost tvorbě bezpečnostních a obranných strategií ve Slovenské republice, včetně poznatků nejlepší praxe. Lze ale usuzovat, že problémy spojené s přístupem $\mathrm{k}$ jejich tvorbě budou velmi podobné a že i doporučení, ke kterým se autoři dopracovali, budou aplikovatelné i ve slovenských podmínkách.

Celkově Ize vědeckou monografii hodnotit velmi kladně. Na poměrně malém prostoru shrnuje nejen podstatné informace, ale poskytuje i doporučení, jak strategické rrízení, respektive tvorbu strategických bezpečnostních dokumentů racionalizovat a zefektivnit. Je zřejmé, že monografie tak, jak ji autoři svým výzkumem podmínili, nemůže postihovat všechny aspekty strategického řízení. Svým obsahem však naznačuje oblasti, které je nutné zpřesnit a dále rozpracovat. To je pro autory jednoznačná výzva do budoucna. Stojí za zvážení upravit monografii do názornější a tím i praktičtější podoby a předložit ji nejen k široké vědecké diskusi, ale zejména ji prosadit do praxe strategických orgánů rízení bezpečnosti a obrany.

Autor: Ing. Vladimír Karaffa, CSc. (plk. gšt. v.v.), nar. 1950. VVŠ PV ve Vyškově, postgraduální studium VA Brno, Marshallovo centrum strategických a ekonomických studí v Garmish-Partenkirchenu, kurz GŠ VA Brno. Vykonával r̆adu logistických, velitelských a pedagogických funkcí na stupni útvar a motostrelecká divize a ve vojenském školství. Působil v Institutu pro výzkum operačního umění v Brně a v Ústavu obranných studií v Praze-Braníku a ve vedoucích funkcích na bývalé Sekci obranného plánování MO. 3 roky pracoval na operačním velitelství NATO v německém Heidelbergu. Od r. 2003 byl náčelníkem Správy doktrín Ředitelství výcviku a doktrín ve Vyškově. V r. 2007 ukončil služební poměr vojáka z povolání. Potom pracoval na Sekci obranné politiky a strategie $\mathrm{MO}$, jako ředitel sekce-personální ředitel $\mathrm{MO}$ a ředitel Centra bezpečnostních a vojenskostrategických studí UO v Brně. V současné pưsobí v rámci bezpečnostní komunity ČR a jako lektor na několika vysokých školách. 


\section{Otiskli jsme před 100 lety}

Vážení čtenáři,

předkládáme vám článek publikovaný v našem časopise č. 2/1921. Jedná se o příspěvek kapitána gen. št. Josefa Kopáče ke stému výročí úmrtí císaře Francouzů Napoleona Bonaparta.

Dozvíte se, jak bylo nahliženo na někdejšího francouzského vojevůdce před sto lety.

Tento i další historické články si můžete prohlédnout, přečíst nebo stáhnout na webových stránkách našeho časopisu www.vojenskerozhledy.cz v nabídce archivu. 


\section{Kapitain gen. št. JOSEF KROPÁC: \\ NAPOLEON.}

Slavnostni přednáška konaná dne 4. května 1921 ve vojenské akademii v Hranicich.

Zitra $v$ šest hodin večer je tomu sto let, co zemřel na ostrově Svaté Heleny nejslavně̌̌š cisař Francouzů a největši vojevůdce všech věkủ a národů Napoleon Bonaparte. Ukládá nám to nejen pieta a úcta, kterou v srdci lidském vzbuzuje vzpomínka na každého velikána světových dějin, nýbrž také sympatie, která poji národ československý s velikým národem francouzským, že jsme se zde shromáždili, abychom oslavili skromným vojenským zpúsobem tento památný den. Každý národ má své vůdce, hrdiny, umělce a mučedniky, jejichž jména zaznamenávaji $\mathbf{s}$ hrdostí dějiny národní a jež tkví po století a tisíciletí v paměti potomkủ. Jména takových mužủ zná však též každý vzdělaný člověk na celém světě a obdivuje jejich činy, vlastnosti a zásluhy.

Známe tedy i my již z národní školy Napoleona, o němž nám vypravuje i sebe menši kniha dějepisná, známe Napoleona, jenž zajimá především nás vojáky jako nejslavněǰsi vojevůdce, jehož čelo zdobi nesmrtelné vavříny, ziskané na bojištich tři dilú světa, v Evropě, v Africe a v Asii. Pohližíme na Napoleona jakožto na nejmužnějšiho representanta národa francouzského, jenž dostoupil $\mathrm{z}$ prostého poručíka až $\mathrm{k}$ výši majestátu a rozšriril hranice své vlasti na severovýchodě až $k$ Hamburku, na jihovýchodě až $k$ věčnému městu Rímu. Když byl na vrcholu své slávy, stálo pod jeho svrchovaností též západní Německo (spolek rýnský), Svýcarsko, Polsko (velkovévodstvi varšavské), Illyrie, celý poloostrov italský a Spanělsko. Tím vzkrísil Napoleon myšlenku imperia, odhodil politický systém rovnováhy moci evropských jako ničemnou hračku do kouta a ukázal užaslé Evropě ideál světovlády po způsobu císarư antického Ríma. Od doby Karla Velikého neměl nikdo takové moci v Evropě jako Napoleon. Historie nazývá dobu, ve které žl Napoleon, dobou napoleonskou, což svědči nejlépe o jeho geniálnosti a slávě. Naplnil svět leskem svého jména jako meteor a vzbuzoval, když klesl s výše své, svým utrpením ve vyhnanstvi na osamělém skalisku uprostřed okeánu Atlantického soucit šrokých kruhủ také mimo Francii.

Vypravovati životopis Napoleonův znamená vypravovati dějiny Evropy na rozhrani XVIII. a XIX. století. Jsem přesvědčen, že vám stručným obrazem života Napoleonova nepodám nic nového, myslim však, že oslavíme jeho památku, když vzpomeneme alespoň nejdúležitějšich a nejslavnějších událostí $v$ jeho životě. Napoleon válčil proti všem téměr̆ státům a národům v Evropě, jimž zasadil často rány velice bolestné. Nemám $\mathrm{v}$ úmyslu otvírati tyto rány a radovati se snad nad neštěstím, které stihlo tehdy ten neb onen stát 
evropský. Chci vás pouze vésti dějinami, jejichž ohniskem byl Napoleon, podotýkaje, že historik sice nezapominá, posuzuje a vypravuje však události vždy, nestranně a objektivně, nikdy zlomyslně. Dějiny světové jsou osudem a soudem světovým; studujeme je proto, abychom si našli nejen vzorné charaktery a činy, jež chceme napodobiti, nýbrž poznali též chyby a pohromy, $z$ nichž se chceme rovněž učiti.

Napoleon se narodil 15. srpna 1769 v Ajacciu na Korsice. (Stopujeme-li 400 rokú do minulosti, obdržime rok 1369 , v němž se narodil náš mistr Jan Hus.) Byv vychován na vojenských školách v Brienne a v Pařiži, stal se Napoleon roku 1786, tři roky před vypuknutim velké revoluce francouzské, poručíkem dělostřelectva. Pro své účastenstvi na vzpouře, vypuknuvši na Korsice, když tam dlel Napoleon právě na dovolené, byl z francouzské armády propuštěn. Roku 1793 obdržel však znovu hodnost dústojnickou a vyznamenal se jako kapitán při obléháni Toulonu tim, že nalezl nejslabši misto pevnosti a radil, aby se na ně útočilo. Útok se zdařil a Napoleon byl povýšen na plukovnika (podle jiných pramenú dokonce na generála).

Roku 1794 byl Napoleon brigádnikem v italské armádě, roku 1795 pracoval $\mathrm{v}$ ministerstvu vảlky $\mathrm{v}$ Pařízi. Téhož roku byla svěřena správa francouzské republiky pětičlennému direktoriu, s nímž udržoval Napoleon vlidné styky. Dne 5. řijna 1795 potlačil Napoleon v Pařízi royalistickou vzpouru kartáčovou palbou. $Z$ vděčnosti byl jmenován vrchnim velitelem italské armády, kterou převzal v roce 1796 ve stáŕi 28 let.

V Italii se proslavil skvělými vitězstvimi (u Montenotte, Dega, Cevy, Mondovi, Lodi) a postoupil po kapitulaci rakouské pevnosti Mantovy r. 1797 až k Lubnu ve Štýrsku. Tím se stal Napoleon velice oblibeným, takže ho direktorium podezrivialo a v obavě, že by se mohlzmocniti vlády, odeslalo ho do Egypta. Napoleon považoval toto posláni za praktickou školu válečnou. Přeplaviv se s vojskem do Egypta, docílil mnoho úspěchủ na pevnině v Egyptě a v Syrii.

Vrátiv se roku 1799 do Pařiz̃e, svrhnul pomocí rady kmetủ vládu direktorû a uvedl v život novou konsulárni ústavu. Sám se stal prvním konsulem, přibral si však dva spolukonsuly jako poradce. Za několik měsicú ustoupila rozháranost doby předešlé pořádku, takže bylo možno zahájiti na bojištích v Italii a v Bavorsku nové operace. Po Napoleonově vitězstvi u Marenga v Piemontsku roku 1800 byl obnovem v Evropě roku 1801 zase mir.

Roku 1802 byla Napoleonovi udělena doživotni dủstojnost konsulská, a když roku 1804 potlačil vzpouru, kterou proti němu zdvihli přivrženci rodu Bourbonského, byl zvolen dne 2. prosince 1804 za císaře Francouzú. Rok na to se stal pak králem italským, kde však ponechal vládu Evženu Beauharnaisovi, synu své první manželky Josefiny Beauharnais.

Roku 1805 válčil Napoleon proti Anglii, Rakousku, Rusku, Švédsku a Neapolsku a dobyl dne 2. prosince 1805 skvělého vitězstvi v bitvě tři císařu u Slavkova na Moravě. V roce 1806 pokořil Prusko vitězstvim u Jeny a Auerstädtu a roku 1807 ujednal výhodný mir také s Ruskem, jež bojovalo tehdy po boku Pruska. Od té doby byl ruský car Alexandr I. po nékolik let spojencem Napoleonovým.

Léta následujicí bojoyala vojska Napoleonova na poloostrově Pyrenejském, načež přivtěleno Španělsko k panstvi cisaře Francouzú. Vojenské operace ve Španělsku nebyly ještě ukončeny, když vypukla nová válka Francie s Rakouskem. Po bitvě u Asprũ o svatodušnich svátcích roku 1809, v niž byl Napoleon arciknižetem Karlem poprvé poražen, zdálo se, že tentokráte zústane Rakousko vitězem. Bitva u Wagramu však obrátila znovu válečné štěsti ve prospěch Napoleonưv, jenž pojal po uzavřeni miru s Rakouskem dceru cisaře Františka II., Marii Louisu, za druhou manželku. Tehdy byl Napoleon na vrcholu své slávy a moci. Novým manželùm se narodil v březnu 
roku 1811 syn a dědic trůnu Napoleon II., jemuž byl dán již v kolébce titul krále řimskẻho.

Roku 1812 se zkalilo přátelství Napoleonovo s Ruskem, načež podnikl Napoleon $\mathrm{s}$ púlmilionovou armádou, $\mathrm{v}$ niž byli zastoupeni národové téměr̆ celé Evropy, válečnou výpravu do vzdáleného Ruska. Podařilo-li se již Rakousku v roce 1809 vložiti velení armády do rukou znamenitého vojevúdce arciknižete Karla, jenž vzal Napolenovi slávu nepřemožitelného vủdce, postavili nyni Rusové vynikajiciho maršálka Kutuzova v čelo svého vojska. Jakmile se to Napoleon dověděl, charakterisoval slovy: „C'est lui! - On je to!“ svého již známého soupeře.

Neštastný výsledek ruského válečného taženi roku 1812 nepodlomil nikterak pevnou vủli Napoleonovu poraziti neprritele. Chceme-li porovnati porážku Napoleonovu v roce 1812 s katastrofou české armády dne 8. listopadu 1620 na Bilé hoře, vidime ohromný rozdil. Neni zapotřebi složiti po prohrané bitvě zbraně a poddati se na milost vitězi. Kdežto český král Bedřich Falcký po nešlastné bitvě utekl z Prahy do Vratislavě, zanechav ubohou zemi českou svému osudu, spěchal Napoleon v prosinci 1812 rychlou jizdou na saních do Pařiže, aby pracoval s obrovskou energii ihned na utvořeni nové armády, se kterou pak zahájil již na jaře roku 1813 k největšimu překvapení spojencủ (Ruska, Pruska a později též Rakouska) nové vitězné operace. Poraziv spojence v bitvách u Groß-Görschenu čili Lützenu nedaleko Lipska, u Budišina (Bautzen) a Wurschenu na Sprévě v Horni Lužici a u Dráżdan, ustoupil na Lipsko, kde pak podlehl soustředěnému útoku spojencủ v krvavých dnech 16., 17., 18. a 19. ŕijna 1813.

$\mathrm{Na}$ počátku roku 1814 překročili spojenci Rýn. Ačkoliv dobyl Napoleon $\mathrm{v}$ některých srážkách $\mathrm{s}$ jednotlivými sbory spojenců vitězstvi, přece nemohl zastaviti postup nepřitelûv. Spojenci obsadili Pařiž a prohlásili Napoleona za zbavena trúnu. Zdrcen jsa tak ohromným neštěstim, pokusil se Napoleon ve slabé chvilce otráviti se opiem, ale dávka, které požil, neúčinkovala smrtelně; byl zachován při životě. Spojenci dosadili na uprázdněný trůn francouzský znovu Bourbony, ponechali však Napoleonovi dủstojnost suverenniho knižete na ostrově Elbě.

Za vlády bourbonské nastaly ve Francii brzy zase neutěšené poměry předrevolučni, což vyvolalo nespokojenost občanstva. Proto opustil Napoleon, jenž dostával z Francie o všem zevrubné zprávy a nevzdal se naděje na obnoveni své dřivějši slávy, tajně Elbu a objevil se dne 1 . března $1815 \mathrm{v}$ přistavě Cannes znovu na francouzské půdě. Vojsko bourbonské, proti němu vyslané, $s$ nadšenim a jásotem prešlo $k$ svému slavnému vủdci dob minulých, jenž pritáhl do Pařiže a ujal se znovu vlády. Chtěl vyjednávati s evropskými mocnári, jejichž diplomaté byli tehdy shromážděni na kongresu vídeňském, o zachováni miru. Kongres však zamitl tento návrh a zahájil proti Napoleonovi novou válku. Napoleon s armádou naspěch vyzbrojenou porazil sice maršálka Blüchera u Ligny, podlehl však dne 18. června presile spojencủ v památné bitvě u Waterloo.

Vzdav se vlády, odebral se do Malmaisona (severně od Remeše) a odtud do atlantického přistavu Rocheforta, kde vstoupil na anglickou lod Bellerofon, aby se přeplavil do Ameriky. Anglie jej však považovala za válečného zajatce a vymohla si souhlas velmoci, aby ho směla odvézti na ostrov Svaté Heleny.

Zde pak zakotvila lod" „Northumberland“ dne 15 . rijina 1815 a Napoleonovi vykázán statek Longwood za obydli. Prázdný svŭj čas věnovat Napoleon diktováni svých paměti. Vlivem zhoubného podnebi a nedostatkem pohybu počal již roku 1818 nebezpečně churavěti. Polepšeni, jež nastalo, netrvalo dlouho; dne 5 . května 1821 Napoleon dokonal. 
Roku 1840 byly jeho tělesné pozústatky převezeny do Francie a k věčnému odpočinku slavnostně uloženy v dómě invalidủ. Tím bylo vyhověno přání, jež vyslovil Napoleon ve své obšírné posledni vủli a jež znělo: „Preji si, aby múj popel odpočival při březich Seiny, uprostřed francouzského národa, který jsem tolik miloval".

Dokončiv životopis Napoleonưv, smim snad ještě věnovati několik slov jeho válečnictvi, jež se stalo vzorem všem vojevûdcủm pozdějšich věkú.

V prvnich válkách revolučnich připominal zpủsob válčeni ještě na války posični a systém kordonový. Operujici armády se pohybovaly velmi pomalu a opatrně, aby nepozbyly spojeni se zápolím, kde byla jejich zásobovaci skladiště. Vojevúdcové vyhýbali se rozhodujici bitvě a snažili se donutiti nepřitele manevrovánim $k$ ústupu. To se jim podařilo, jakmile ohrožovali týl neprítelúv, nebơ i nepritel nesmèl bỷti odriznut od svých zásobáren. Cile války nebyly dalıkosáhlé. Šlo obyčejně jen o dobyti nějaké krajiny neb určitého města, nikdy však o to, aby byl neprítel zničen. Všechna dúležitá mista na bojišti (posice) byla opevňována a také obsazena, čimž byla sila polni armády povážlivě roztřištěna. Proto nedošlo téměř nikdy $k$ větši bitvě; byly svedeny jen pútky a ten, kdo v nich zvitězil, vyhrál válku.

Tento zpùsob válčeni byl na konci XIX. století zatlačen válkou pohybovou, již povznesl Napoleon na vrchol dokonalosti. Misto zásobováni ze zásobáren byl zaveden systém rekvisični, jimž nabyla armáda větši pohyblivosti. Aby se zásoby zemé lépe využily, pochodovala armáda $\mathrm{v}$ široké frontě, v několika proudech čili kolonách, v t. zv. echiquier. Jednotlivé části armády, pochodujici samostatně na určité komunikaci, byly složeny ze všech zbraní, aby mohly vésti několikahodinový boj samostatně. To byly divise, jejichž složeni Napoleon zdokonalil, takže byly malými, více méné samostatnými armádami.

Napoleon hledá dưrazně rozhodujici bitvy a zanedbává za timto účelem veškeré úlohy a cile vedlejši. Stane-li se, že musi operovati na více bojištich, nerozděli své vojsko stejnoměrně, nýbrž soustředi hlavni silu na onom bojišti, které považuje za nejdúležitější.

Armádu pro hlavni boj určenou shromáždi Napoleon v přiznivě položené a souvislé územi tvořici nástupné oblasti, ze které zaháji operace pokud možno dřive než nepřitel, a to výbojem, ofensivou. Při této ofensivě vyšle velká tělesa jezdecká daleko dopředu, aby obdržel zprávy o nepriteli. $\mathrm{Na}$ základě těchto zpráv disponuje pak Napoleon s geniálnim strategickým rozhledem své vojsko proti nejdúležitějšim bodủm, které maji pro operace a prú. běh bojú rozhodujici význam. Za prriklad uvádím návrši Pratecké, proti němuž zasadil Napoleon v bitvě u Slavkova svou blavni silu, aby prolomil bitevni frontu neprítelovu. Jeden $\mathrm{z}$ mých učitelủ na válečné škole pronesl při přednášce o bitvě u Slavkova větu: „In jeder Schlacht gibt es eine Höhe von Pratze - v každé bitvě najdete návrši Pratecké!"“ Tim chtěl řici, že jest úlohou každého velitele hledati v bitevnim terénu nejdủležitějši bod, jenž jest kličem $k$ vitězstvi.

Cilem útoku Napoleonova jest vždy nepřátelská armáda; neni-li známo, kde jest nepřitel, zaháji Napoleon ofensivu směrem na hlavni město nepřitelovo. Pŕi postupu jest armáda rozčleněna na několik pochodových proudú, které se bliži tím vice $k$ sobě, čim bliže přicházeji $k$ neprriteli (jinak rečeno, pochodový echiquier se postupně zúžuje). Nesmi se státi, aby některá část armády prišla $k$ rozhodujici bitvě pozdě.

Rychlosti svých pohybủ napadne Napoleon obyčejně svého protivnika, jenž se pohybuje pomaleji. $Z$ postupu se vyvine bez zastávky bitva, $k$ niž stảhne Napoleon veškeré sily, které má $k$ disposici. Vedlejším podnikủm věnuje jen nepatrné ćásti armády nebo, ie-li to možné, vưbec nic. V bitvě 
dosažených úspěchů využije Napoleon $\mathrm{k}$ intensivnimu pronásledováni neprítele, aby jej zničil úplně. Za cil války považuje Napoleon vủbec zničeni nepřitele, všech jeho sil, jeho státu.

Napoleon jest též výborným státnikem a diplomatem, jenž dovede zameziti spolky mezi svými protivniky a zaháji válku v době nejvhodnějši. Jeho válečné připravy jsou velice dủkladné, jeho vojsko jest výborně a účelně organisováno. Mohl bych ke každé z těchto vět, které jsem právě pronesl,podati přiklady z válečných taženi Napoleonových a mohl bych též dokázati, že se osvědčila tato pravidla napoleonské strategie také v posledním velkém zápase světovém. Myslím však, že bych se tím přiliš odchýlil od slavnostniho rázu této přednáśky a přešel do koleji učitele strategie. Chtěl jsem pouze načrtnouti pravidla, podle nichž se řidil veliký Napoleon a po něm všichni vynikajici vojevúdcové doby nynějši. V těchto pravidlech a jejich mistrovském provedeni vrcholi válečné umění Napoleonovo, jež doprovázelo po dlouhou rradu let také nevidané štěstí. Př́činou jeho neúspěchủ byla roku 1812 pouze ruská zima, roku 1813 a 1814 špatná vojenská hodnota jeho armády. Jeho konečnou porážku v r. 1815 zavinili podřizeni velitelé.

Též v jiných oborech veřejného života, obzvláště ve správě státu a v národnim hospodářstvi, vykonal Napoleon činy tak neobyčejné a pronikavé, že budily u vrstevnikú se strachem zároveñ obdiv a proměnily podstatně celou soustavu společnosti evropské. Nepopiratelnou zásluhou jeho zústane, že opět obnovil, napravil a očistil, co králové zkazili, filosofové převrátili a mužové hrůzy zničili nebo pošpinili.

Dokončujeme timto své vzpominky na slavného, obdivuhodného a obzvláště od svých vojáků zbožňovaného cisaře a vojevůdce Napoleona I. Vzdejme počest jeho tělesným pozůstatkúm a všem jeho vynikajicim činủm a složme v duchu $k$ jeho náhrobku $v$ dómě invalidủ vavřinový věnec, propletený ratolestmi naši české lipy! 


\section{OBSAH}

NATO po skončení studené války

3

Jan Eichler

Bojové ctnosti a whistleblowing: ztracená věrnost a nepochopená odvaha

Dragan Stanar

Použitelnost umělé inteligence v rozhodovacím procesu pozemních sil

Paul Tudorache

Poradenský tím asistencie bezpečnostným silám - východiská a výsledky

Jaroslav Kompan, Michal Hrnčiar

\section{PŘíLOHA}

Recenze monografie autora

PROCHÁZKA, Josef a Pavel NEČAS. Přístupy k tvorbě bezpečnostních a obranných strategií.

Vladimír Karaffa

Otiskli jsme před 100 lety

Redakce 


\section{CONTENTS}

NATO after the end of the Cold War

Jan Eichler

Martial Virtues and Whistle-Blowing: Loyalty Misplaced and Courage Misunderstood

Dragan Stanar

Applicability of Artificial Intelligence in Decision-Making for Land Forces

Paul Tudorache

Security force assistance advisory team - inputs and outcomes

Jaroslav Kompan, Michal Hrnčiar

\section{ENCLOSURE}

Review of the Author's Monography

PROCHÁZKA, Josef and Pavel NEČAS. Approaches to Security and Defence

Strategy Formulation.

Vladimír Karaffa

Printed 100 years ago

Editorial Staff 


\section{Časopis VOJENSKÉ ROZHLEDY}

čtvrtletník

Vydává:

Ministerstvo obrany České republiky, Tychonova 1, 16001 Praha 6 - Dejvice

Vydávající instituce:

Univerzita obrany v Brně, Kounicova 156/65, 66210 Brno

IČO: 60162694

Vojenské rozhledy č. 2/2021

Ročník: XXX. (LXII.)

Datum předání do tisku: 8. června 2021

Rozšiřuje:

OKP MO, distribuce, Rooseveltova 23, 16105 Praha 6

Olga Endlová, tel. 973215 563, endlovao@army.cz

Redakce: Ing. Petr Koziel, telefon: 973443499

E-mail: vojenskerozhledy@unob.cz

Redakční rada: Ing. Ján Spišák, Ph.D. (předseda), PhDr. Miloš Balabán, Ph.D., pplk. Marco Biagini, Ph.D., M. A., doc. PhDr. Felix Černoch, CSc., plk. Florian Cîrciumaru, Ph.D., Mgr. Lukáš Dyčka, Ph.D., doc. PhDr. Jan Eichler, CSc., Mgr. et. Mgr. Jakub Fučík, Ph.D., prof. Dr. hab. Artur Gruszczak, plk. gšt. doc. Ing. Vladan Holcner, Ph.D., Ing. Vladimír Karaffa, CSc., prof. Ing. Aleš Komár, CSc., PhDr. Tomáš Kopečný, Mgr. Josef Kraus, Ph.D., Mgr. Tomáš Kučera, Ph.D., genmjr. Ing. Miloslav Lafek, prof. Juha-Matti Lehtonen, Ph.D., plk. gšt. Ing. Tomáš Novotný, Ph.D. MSc., Mgr. Martin Riegl, Ph.D., plk. Chris Rogers, MA, MMAS., doc. Hofrat Univ. Dr. Erwin Schmidl, Ph.D., Dr. hab. Zdzislaw Sliwa, RNDr. Pavel Štalmach, MBA, Ing. Miroslav Šuhaj, Ph.D., Mgr. et Mgr. Lukáš Tichý, Ph.D.

Tajemník redakční rady: Ing. Petr Koziel

Sídlo redakce: Kounicova 65, 66210 Brno

Adresa pro zasílání pošty: Vojenské rozhledy - redakce, Kounicova 156/65, 66210 Brno

Časopis Vojenské rozhledy v elektronické podobě naleznete na:

http://www.vojenskerozhledy.cz/

Časopis je evidován:

- v evropské databázi ERIH PLUS

- $v$ seznamu recenzovaných neimpaktovaných periodik vydávaných v České republice

- v mezinárodní databázi Index Copernicus Journals Master List 2015

- v katalogu Národní knihovny České republiky

- v databazzi Central and Eastern European Online Library GmbH (CEEOL)

- $v$ Crossref database (DOI)

- $v$ databázi Directory of Open Access Journals (DOAJ)

Od čísla 1/2018 je časopis indexován v databázi Emerging Sources Citation Index na Web of Science

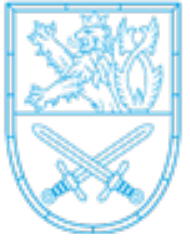

Grafická úprava: Adéla Zemanová

Tiskne: VGHMÚř Dobruška

Evidenční č́slo: MK ČR E 6059

Identifikační číslo: ISSN 1210-3292 (print), ISSN 2336-2995 (on-line)

doi: 10.3849/2336-2995 